\title{
SCHOOL DESEGREGATION LITIGATION \\ IN THE SEVENTIES AND THE USE OF SOCIAL SCIENCE EVIDENCE: AN ANNOTATED GUIDE
}

\author{
Betsy Levin* and Philip Moise ${ }^{\dagger}$
}

\section{INTRODUCTION}

\section{A. The Use of Social Science Research in Litigation}

Courts on occasion refer to sources outside the trial record to establish "constitutional facts." 1 This is not a new practice, nor a practice that began with Brown $v$. Board of Education, ${ }^{2}$ nor even a practice that is confined to school desegregation litigation. ${ }^{3}$ Justice Harlan's use of medical and social science data in Lochner $\%$ New York ${ }^{4}$ in 1905 marks one of the earliest attempts to introduce non-legal material. ${ }^{5}$ This was shortly followed by Muller $v$. Oregon, a case involv-

* Associate Professor of Law, Duke University.

† J.D., Duke University, 1974; member of the North Carolina bar; presently on active duty with the United States Army, Judge Advocate General's Corps, Fort Sheridan, Illinois.

Several memoranda by attorneys who have been or are litigating these issues, or who are close students of such litigation, were prepared for the Conference on The Courts. Social Science, and School Desegregation, held in August 1974 in South Carolina. The memoranda presented various views of the issues courts presently face in school desegregation litigation. This article has drawn on the insights provided in those memoranda, although the authors bear the final responsibility for the interpretations and conclusions in this article.

The contributors, whom the authors gratefully acknowledge, were Derrick A. Bell. Jr., Professor of Law. Harvard University; Norman J. Chachkin, Staff Attorney, NAACP Legal Defense and Educational Fund, Inc.; J. Harold Flannery, Director, Lawyers Committee for Civil Rights under Law; Owen M. Fiss, Professor of Law, Yale University; Harold Horowitz, Professor of Law. University of California at Los Angeles; Sanford Jay Rosen, Legal Director, and Carlos Alcala, Interim Director of Educational Litigation, Mexican-American Legal Defense and Educational Fund; and William L. Taylor, Director. The Center for National Policy Review.

1. For the difference between adjudicative facts and legislative or constitutional facts see $2 \mathrm{~K}$. Davis, Administrative Law Treatisf $\$ 15.03$ (1958). See also Hant \& McNaughton. Evidence and Inference in the Lau, 87 DAEDALUS 41 (1958).

2. 347 U.S. 483 (1954).

3. Some have suggested that the Supreme Court's use of social science as evidence in Brown was an unprecedented innovation, thus explaining the fierce debate over the propriety of using such evidence in a legal opinion. See, e.g., P. Roses. The Supreme Court and Social Science 169-70 (1972). Perhaps, however, the outcry that was raised was due to the fact that the case was not a relatively non-controversial one of low visibility (e.g... an antitrust case involving the introduction of extensive economic data), but a case capable of overturning the social structure of the South, based on segregation and racism.

4. 198 U.S. 45 (1905).

5. See P. Brest, Process of Constitutional Decision Making 938-39 (1975). 
ing a maximum hour law for women, in which Louis Brandeis filed a 113-page brief in support of the law's constitutionality, drawing upon such sources as surveys, government statistics, factory reports, and the opinions of doctors, employers, and employees. ${ }^{6}$ The so-called "Brandeis Brief" was cited with approval by the Court. ${ }^{7}$ Since then, the courts have frequently resorted to nonlegal research to support legal conclusions. Trademark and antitrust litigation, for example, have been areas long dominated by empirical social science evidence. Empirical social science data and research also have been cited in cases involving the death penalty, ${ }^{8}$ six-man juries, ${ }^{9}$ legal insanity rules, ${ }^{10}$ and the use of test scores and education credentials for employment. ${ }^{11}$ Social science data

6. Brief on behalf of the people, prepared by Louis D. Brandeis and Josephine Goldmark, Muller v. Oregon, 208 U.S. 412 (1908).

7. 208 U.S. at 419-20 n. 1. Professor Paul Freund would distinguish the "Brandeis Brief" from the use of psychological and sociological research in Brown on the ground that the Brandeis Brief was used to support legislation-and thus was in line with the usual presumption of constitutionality. In Brown, however, extra-legal evidence was used to attack legislation. P. Freund, The Supreme Court of The United States 152 (1961).

8. Furman v. Georgia, 408 U.S. 238 (1972).

9. In Williams v. Florida, 399 U.S. 78 (1970), Justice White, writing for the majority, noted that "[w] hat few experiments have occurred ... indicate that there is no discernible difference between the results reached by the two different-sized [6-man and 12-man] juries," $i d$. at 101, citing six sources which were not based on empirical research by social scientists but on the experience of lawyers and judges in reduced jury jurisdictions. Justice White continued in Williams: "In short, neither currently available evidence nor theory suggests that the 12-man jury is necessarily more advantageous to the defendant than a jury composed of fewer members." Id. at 101-02. As an example of "theory," the Justice cited H. Kalven \& H. Zeisel, The American Jury 462-63, 488-89 (1966) for the proposition that "jurors in the minority on the first ballot are likely to be influenced by the proportional size of the majority aligned against them." 399 U.S. at $101 \mathrm{n}$. 49 . Justice White concluded that:

If a defendant needs initially to persuade four jurors that the State has not met its burden of proof in order to escape ultimate conviction by a 12-man jury, he arguably escapes by initially persuading half that number in a six-man jury; random reduction, within limits, of the absolute number of the jury would not affect the outcome.

399 U.S. at 102 n. 49.

It is of interest to note that one of the authors of the study cited by Justice White has since written with regard to use of this data from The American Jury: "It is only fair to point out that the findings were quite different" from the way in which they were stated by Justice White. Zeisel, .. . And Then There Were None: The Diminution of the Federal Jury, 38 U. ChI. L. Rev. 710,719 (1971). Zeisel noted that the study suggested that for a juror to hold out against a majority, it was necessary for him to have a companion. Thus although the odds are the same at five to one or ten to two, at ten to two the dissenters will hold out a much higher percentage of the time than if one juror is alone at five to one. Id. at 719-20.

10. In Durham v. United States, 214 F.2d 862 (D.C. Cir. 1954), the D.C. Court of Appeals relied in part upon articles on legal insanity by psychiatrists and other medico-legal writers, $i d$. at 870-74, in deciding that the traditional MNaghten rule for determining the availability of the defense of insanity in a criminal case (defendant presumed sane unless suffering from a disease of the mind such that he did not know the difference between right and wrong) should be abandoned for a new rule: whether or not the "unlawful act was the product of mental disease or mental defect." 214 F.2d at 875 . The court recently reconsidered the Durham rule governing the insanity defense and replaced it with the test given in $\$ 4.01$ of the American Law Institute's Model Penal Code. United States v. Brawner, 471 F.2d 969, 973 (D.C. Cir. 1972).

11. In Griggs v. Duke Power Co., 401 U.S. 424 (1971), the Court relied in part on a study by the Equal Employment Opportunity Commission showing that 58 per cent of white applicants passed a battery of intelligence tests including that used by Duke Power Company, while only 6 per 
and research findings were even brought to bear on the racial area before Brown. The Supreme Court struck down state court enforcement of racially restrictive covenants in $1948 .{ }^{12}$ While it is not apparent in the Supreme Court's opinion, sociological material was introduced at every stage-from the initial trial through the argument before the Supreme Court. ${ }^{13}$ In a case concerning the refusal of the University of Texas Law School to admit blacks, ${ }^{14}$ anthropological evidence of the relationship between intelligence and race was introduced at the trial. ${ }^{15}$

In a substantial number of these cases, judges unfamiliar with the methodology of social science research have attempted unsuccessfully to assimilate complex data which were equivocal and ambiguous. Ambiguity has led to misunderstanding, and of ten to misinterpretation and misuse of the research introduced into evidence. ${ }^{16}$ Courts have disagreed as to the weight to be assigned social science research findings, ${ }^{17}$ just as social scientists themselves have

cent of black applicants passed. Id. at $430 \mathrm{n}$. 6. The Supreme Court held that these data established a prima facie case of discriminatory employment criteria, thereby shifting the burden to the Company to show that its requirements were significantly related to a successful job performance, a burden which the Company was unable to meet on the basis of the evidence introduced. Id. at 431 . Similarly, in Douglas v. Hampton, 512 F.2d 976 (D.C. Cir. 1975), two studies were used to establish a prima facie case of the racially disproportionate impact of the Federal Service Entrance Examination (FSEE). Id. at 982-83. These studies showed that the passing rate on the FSEE for those having attended predominantly black colleges was between 12.4 per cent and 8.6 per cent, while for those having attended predominantly white colleges it was between 60.2 per cent and 42.1 per cent. $I d$, at 982 .

12. Shelley v. Kraemer, 334 U.S. 1 (1948).

13. Kohn, Social Psychological Data, Legislative Fact, and Constitutional Law, 29 Geo. Wash. L. Rev. 136,137 (1960).

14. Sweatt v. Painter, 339 U.S. 629 (1950).

15. Kohn, supra note 13, at 140.

16. See, e.g., Levin, Education, Life Chances and the Courts: The Role of Social Science Evidence, 39 Law \& Contemp. Prob. no. 2, at 217 (1975); Rosenblum, A Place for Social Science Along the Judiciary's Constitutional Law Frontier, 66 Nw. U.L. Rev. 455, 460-61 (1971).

17. In the capital punishment decision, Furman v. Georgia, 408 U.S. 238 (1972), Justice Douglas, concurring, cited Koeninger, Capital Punishment in Texas, 1924-1968, 15 Crime \& Delinquency 132 (1969) and H. Bedau, The Death Penalty in America 474 (1967) for statistics showing that blacks were executed more frequently than whites. 408 U.S. at 250 n. 15. Justice Marshall, also concurring, cited T. Sellins, The Death Penalty, A Report for the Model Penal Code Project of THE American LAw INSTItute (1959) as showing that murders do not increase when capital punishment is banned or decrease in areas that impose the death penalty, 408 U.S. at $348-50$, and, citing other studies, argued that "[i]n light of the massive amount of evidence before us, I see no alternative but to conclude that capital punishment cannot be justified on the basis of its deterrent effect." 408 L.S. at 354. Concurring also, Justice Stewart-relying upon H. BEDac, supra-purported to show that the evidence of the deterrent effect of the death penalty is so inconclusive that it is insufficient to support the conclusion that the death penalty is not justified. 408 U.S. at 307-08. Justice Powell, dissenting, also drew upon these studies to show the contradictory nature of the evidence of both the deterrent effect of the death penalty and the possible discrimination involved in its imposition. 408 U.S. at 434-50, 454-56.

The only justice to directly controvert the assertion that the death penalty is imposed arbitrarily was Chief Justice Burger, who stated in his dissent that the assertion had "no empirical basis." 408 U.S. at 389, citing for support of the contrary proposition, Note, A Study of the California Penalty Jury in First-Degree-Murder Cases, 21 STAN. L. Rev. 1297 (1969) and H. KALveN \& H. Zeisel, supra note 9. See also Maxwell v. Bishop, 398 F.2d 138 (8th Cir. 1968), vacated and remanded on other grounds, 398 U.S. 262 (1970). 
differed as to the scientific validity of the same studies. The net result of this attempted union of law and social science understandably has been unsatisfactory for jurists and social scientists alike. Mutual distrust has often been the result, and valuable insights have been lost or denied as judges and juries have sought to separate hard fact from educated speculation.

It is not the purpose of this article to explore the host of problems which presently prevent the effective application of social science research to the judicial process. There are numerous articles which deal with those problems. ${ }^{18}$ It is enough for our purposes that courts have considered and will continue to consider social science evidence in an attempt to discern the factual and legal truth of school desegregation questions. This article surveys the legal issues presently confronting courts as they decide school desegregation cases, and the extent to which social science research has been brought to bear on those issues.

\section{B. Social Science and the Footnote \\ Eleven Debate}

When Brown was decided, there was considerable debate concerning the extent to which the Supreme Court's opinion rested upon the social science evidence cited in footnote eleven of the Brown opinion, ${ }^{19}$ rather than upon principles of law. ${ }^{20}$ The strongest voice to challenge the import of footnote eleven was that of Edmond Cahn: ${ }^{21}$

I would not have the constitutional rights of Negroes-or of other Americans-rest on any such flimsy foundation as some of the scientific demonstrations in these records ... . [S]ince the behavioral sciences are so very young, imprecise, and changeful, their findings have an uncertain expectancy of life. Today's sanguine asseveration may be cancelled by tomorrow's new revelation-or new technical fad.

18. See, e.g., Rosenblum, supra note 16; Hazard, Limitations on the Uses of Behavioral Science in the Law, 19 CaSe W. Res. L. Rev. 71 (1967); Lochner, Some Limits on the Application of Social Science Research in the Legal Process, 1973 Law \& Social Order 815.

19. Brown v. Board of Educ., 347 U.S. 483, 494-95 n. 11 (1954).

20. See, e.g., C. Swisher, The Supreme Court in Modern Role 158-62 (1954); W. Workman, The Case for The South, 26, 30, 197 (1960); Greenberg, Social Scientists Take the Stand: A Review and Appraisal of Their Testimony in Litigation, $54 \mathrm{MrCH}$. L. Rev. 953.(1956); Sutherland, The American Judiciary and Racial Desegregation, 20 Modern L. Rev. 201 (1957); Cahn, Jurisprudence, 30 N.Y.U.L. REv. 150 (1955); Clark, The Desegregation Cases: Criticism of the Social Scientist's Role, 5 ViLL. L. REV. 224 (1959); Black, The Lawfulness of the Segregation Decisions, 69 Y ALE L.J. 421 (1960).

21. Cahn, supra note 20, at 157, 167. See also Cahn, Jurisprudence, 31 N.Y.U.L. Rev. 182 (1956). Professor Kalven has noted that:

His [Professor Cahn's] fear was that scientific fact having been tendered on the issue, the merits would be thought to stand or fall with it, so that a shift tomorrow in the fashions of science would force a shift in the conclusions about segregation.

Professor Kalven, however, found that fear

unfounded not because the scientific fact might not change, but because it has become clear that neither we nor the Court rested our conviction as to the evils of racial segregation on the scientific proof. That judgment had deeper and perhaps less rational sources.

Kalven, The Quest for the Middle Range: Empirical Inquiry and Legal Policy, in LAW IN A Changing AMERICA 56, 66 (G. Hazard ed. 1968). 
Some lower courts did attempt to do what Professor Cahn had feared. A federal district court in Georgia believed that the question presented in Brown-whether segregation of children in public schools is harmful-was a question of fact rather than of law. The judge therefore permitted evidence, much of which was developed after 1954, to be introduced in an attempt to show that ${ }^{22}$

the separation of Negro and white children in the public schools was not determined solely by race or color but rather upon racial traits of educational significance as to which racial identity was only a convenient index. . . [and that the] differences in specific capabilities, learning progress rates, mental maturity, and capacity for education in general . . as well as differences in physical, psychical and behavioral traits ... were ... of such magnitude as to make it impossible for Negro and white children of the same chronological age to be effectively educated in the same classrooms.

The court found, on the basis of the evidence submitted, that both white and black students would be seriously injured by integration and that ${ }^{23}$

[w] hatever psychological injury may be sustained by a Negro child out of his sense of rejection by white children is increased rather than abated by forced intermixture, and this increase is in direct proportion to the number and extent of his contacts with white children.

The Fifth Circuit, however, peremptorily reversed the district court, ${ }^{24}$ and this problem rarely surfaced again in such blatant form. ${ }^{25}$

22. Stell v. Savannah-Chatham County Bd. of Educ., 220 F. Supp. 667, 668 (S.D. Ga. 1963).

23. 220 F. Supp. at 684.

24. 333 F.2d 55 (5th Cir.), cert. denied, 379 U.S. 933 (1964).

$[\mathrm{N}$ ]o inferior federal court may refrain from acting as required by [Brown v. Board of Educ.] even if such a court should conclude that the Supreme Court erred either as to its facts or as to the law. . . We do not read the major premise of the decision of the Supreme Court ... as being limited to the facts of the cases there presented. We read it as proscribing segregation in the public education process on the stated ground that separate but equal schools for the races were inherently unequal. This being our interpretation of the teaching of that decision, it follows that it would be entirely inappropriate for it to be rejected or obviated by this court.

Id. at 61 .

25. But see Evers v. Jackson Municipal Separate School Dist., 232 F. Supp. 241 (S.D. Miss. 1964), which permitted evidence to be introduced to show that separate schools were not injurious, but instead were advantageous to pupils of both races. 1 d. at 244-50. Such testimony included that of seven "distinguished" scientists as "to the existence of such differences between the two groups to constitute a rational basis for separate schooling"-differences between the races in IQ and in cranial capacity and brain size. $1 d$. at 246-47. Evidence was also introduced that the "mixing" of the races in the same school is injurious. Id. at 245. Although District Judge Mize expressed the opinion that this evidence "cr[ies] out for a reappraised and complete reconsideration of the findings and conclusion of the United States Supreme Court in the Brown decision," he nevertheless granted the plaintiff's prayer for an injunction, feeling bound by the Fifth Circuit's prior holding in Stell v. Savannah-Chatham County Bd. of Educ. Id. at 255.

Judge Wisdom, speaking for the Fifth Circuit on appeal, stated that "[t]hese cases tax the patience of the Court." 357 F.2d 653, 654 (5th Cir.), cert. denied, 384 U.S. 961 (1966). In firmly rejecting any further attempts "to overturn Brown on a factual showing," Judge Wisdon declared that the inherent inequality of segregated schools was now a legal principle no longer open to question. Id. 
Since Brown, the courts have continued to refer to social science research in segregation cases, although more frequently in regard to questions concerning the nature and extent of the remedies to be applied, rather than whether segregation is a constitutional violation per se. As the legal questions of school desegregation have become more and more complex (compared to the relatively clear and simple issue presented in Brown), social science research has become less certain and more debatable-or at least it seems so to many lawyers and judges. ${ }^{26}$

The increasing lack of unanimity on the Court may be a reflection of the growing complexity of the issues. Swann $\%$. Charlotte-Mecklenburg Board of Education $^{27}$ marked the end of the unbroken line of unanimous Supreme Court decisions in school desegregation which began with Broun. The cracks in the wall of unanimity first appeared in two cases which followed Swann by only a little over a year-after eighteen years of unanimity in school desegregation cases. Chief Justice Burger dissented in Wright v. Council of the City of Emporia, ${ }^{28}$ joined by Justices Blackmun, Powell, and Rehnquist. The same four concurred only in the result in United States v. Scotland Neck City Board of Education. ${ }^{29}$

The crack widened into a sizable fissure with Keyes v. School District No. 1 (the Denver case). ${ }^{30}$ Justice Brennan wrote the majority opinion; the Chief Justice concurred in the result. Justice Douglas joined the opinion of the Court, but in a separate opinion reprimanded the majority for continuing the de facto-de jure distinction by requiring the plaintiff to produce evidence of the "intent" of school authorities. ${ }^{31}$ Justice Powell wrote an opinion concurring in part and dissenting in part. Justice Rehnquist dissented. Justice White did not participate. Finally, with Milliken $v$ Bradley (the Detroit case),$^{32}$ the unanimous front ruptured completely-Chief Justice Burger writing for a majority which included Justices Rehnquist, Powell, Stewart, and Blackmun; Justice Stewart filed a separate concurring opinion; Justice White dissented, joined by Justices Douglas, Brennan, and Marshall; another dissent by Marshall was joined by the other three dissenters; and Justice Douglas filed a separate dissent.

In attempting to identify the principal issues, it is useful to treat them as clustered around two separate and distinct categories, although in Milliken $v$.

26. Cf. Justice Powell's comments in the Rodriguez case:

$[7]$ his case. . . involves the most persistent and difficult questions of educational policy, another area in which this Courts lack of specialized knouledge and experience counsels against prematue interference. . . On even the most basic questions in this area the scholars and educational experts are divided. Indeed, one of the major sources of controversy concerns the extent to which there is a demonstrable correlation between educational expenditures and the quality of education....

San Antonio Independent School Dist. v. Rodriguez, 411 U.S. 1, 42-43 (1973) (emphasis added).

27. 402 U.S. 1 (1971).

28. 407 U.S. 451 (1972).

29. 407 U.S. $484(1972)$.

30. 413 U.S. 189 (1973).

31. 413 U.S. at $214-16$.

32. 418 U.S. 717 (1974). 
Bradley, the Supreme Court seems to have merged the two so that there may no longer be as clear a line between them as before. Thus, there are a number of issues comprising the first category establishing the violation; i.e., whether a violation of the equal protection clause of the fourteenth amendment has occurred, giving rise to the duty to desegregate the school system. The second category includes issues concerned with remedy; i.e., once it has been determined that the equal protection clause has been violated, what are the permissible remedies which courts can order? This article will examine these two questions and the context in which they arise in today's school desegregation cases, as well as the kinds of social science evidence which the courts draw upon in answering these questions.

\section{I}

\section{Developments in the Law of School Desegregation} From Brown to Swann: A Brief Review ${ }^{33}$

In 1954, four separate cases-from Kansas, South Carolina, Virginia, and Delaware ${ }^{34}$-were consolidated for argument in the Supreme Court. The Court framed the issue before it as being whether "segregation of children in public schools solely on the basis of race, even though the physical facilities and other 'tangible' factors may be equal, deprive[s] the children of the minority group of equal educational opportunities." 35 The. Court then held that the fourteenth amendment forbids such state-imposed segregation of races in public schools: "[I]n the field of public education the doctrine of "separate but equal' has no place. Separate educational facilities are inherently unequal." 36

The Court approved the finding of the Kansas district court which stated: ${ }^{37}$

Segregation of white and colored children in public schools has a detrimental effect upon the colored children. The impact is greater when it has the sanction of the law; for the policy of separating the races is usually interpreted as denoting the inferiority of the negro group. A sense of inferiority affects the motivation of a child to learn. Segregation with the sanction of law, therefore, has a tendency to [retard] the educational and mental development of negro

33. The tortuous process of the development of school desegregation law is traced in Read, Judicial Evolution of the Law of School Integration Since Brown v. Board of Education, 39 LAw \& Contemp. Prob. no. 1, at 7 (1975).

34. Brown v. Board of Educ, of Topeka, 98 F. Supp. 797 (D. Kan. 1951); Briggs v. Elliott, 103 F. Supp. 920 (E.D.S.C. 1952); Davis v. County School Bd., 103 F. Supp. 337 (E.D. Va. 1952); Gebhart v. Belton, 33 Del. Ch. 144, 91 A.2d 137 (1952).

35. Brown v. Board of Educ., 347 U.S. 483, 493 (1954).

36. 347 U.S. at 495 .

37. 347 U.S. at 494. The Court went further and suggested that "[a]ny language in Plessy $v$. Ferguson contrary to this finding is rejected." Id. at 494-95. In Plessy, it will be recalled. Justice Brown noted that

the underlying fallacy of the plaintiff's argument consist[s] in the assumption that the enforced separation of the two races stamps the colored race with a badge of inferiority. If this be so, it is not by reason of anything in the act, but solely because the colored race chooses to put that construction upon it.

163 U.S. 537,551 (1896). 
children and to deprive them of some of the benefits they would receive in a racial[ly] integrated school system.

This finding, suggested the majority, was "amply supported by modern authority," which was named in the now famous footnote eleven of the opinion.

The cases were set down for further argument on the question of appropriate relief. Brown $I^{38}$ was decided the following year and the cases were remanded with the following directions regarding the extent of the equitable remedial powers of lower courts: ${ }^{34}$

In fashioning and effectuating the decrees, the courts will be guided by equitable principles. Traditionally, equity has been characterized by a practical flexibility in shaping its remedies [footnote omitted] and by a facility for adjusting and reconciling public and private needs. [Footnote omitted.] These cases call for the exercise of these traditional attributes of equity power. At stake is the personal interest of the plaintiffs in admission to public schools as soon as practicable on a nondiscriminatory basis. To effectuate this interest may call for elimination of a variety of obstacles in making the transition . . . Courts of equity may properly take into account the public interest in the elimination of such obstacles in a systematic and effective manner. But it should go without saying that the vitality of these constitutional principles cannot be allowed to yield simply because of disagreement with them.

The Court said the objective must be "to effectuate a transition to a racially non-discriminatory school system." (Emphasis added.) ${ }^{40}$

For almost twenty years following the Brown decision, the problem of establishing a constitutional violation rarely presented itself since subsequent cases arose almost exclusively in southern states in which segregation had been constitutionally or statutorily mandated. ${ }^{41}$ This twenty-year struggle to implement Brown in the South was, in large part, only a struggle with the question of remedying admitted state-imposed segregation. In the few cases which arose outside of the South, some courts found only de facto segregation and hence no state action requiring desegregation, ${ }^{42}$ while others reached the opposite result. No non-southern case, however, reached the Supreme Court until Keyes (the Denver case) in 1973.

38. Brown v. Board of Educ., 349 U.S. 294 (1955).

39. Id. at 300 .

40. 349 U.S. at 301 .

41. A few courts expressed the belief that since the constitutional rights of minorities depended on the extent of harm that allegedly stemmed from segregation, a showing of the opposite-that there was no harm-meant that there was no right to be violated. See for example the Stell v. Savannah-Chatham County Bd. of Educ. situation at notes 22-24 supra and accompanying text.

42. Some early lower court cases in which litigants unsuccessfully sought to establish an affirmative right to desegregation without regard to the cause of the existing pattern of segregated schools are Deal v. Cincinnati, 369 F.2d 55 (6th Cir. 1966); Bell v. School City of Gary, 324 F.2d 209 (7th Cir. 1963). In Deal, the plaintiffs had argued that black children would be harmed by attending a racially imbalanced school. The Sixth Circuit, however, held that "[a] finding of educational or other harm is not essential to strike down enforced segregation." Id. at 59. The court went on to say, however, that "a showing of harm alone is not enough to invoke the remedial powers of the law." Id. 
A brief review of the kinds of segregatory plans ${ }^{43}$ which were adopted by states in the early years of litigation-purportedly to remedy segregation - provides some insights into some of the issues with which courts are grappling today.

(1) Pupil Placement Laws. Under pupil placement laws, students were initially assigned to the schools maintained for their race. Requests for transfers were then considered on an individual basis, in light of various "non-racial" factors. In Alabama, the law set forth the following factors, among others, which a board of education should consider in granting or denying a request to transfer: ${ }^{44}$

the psychological qualification of the pupil for the type of teaching and associations involved, ... . the psychological effect upon the pupil of attendance at a particular school; the possibility or threat of friction or disorder among pupils or others; the possibility of breaches of the peace or ill-will or economic retaliation within the community; . . the maintenance or severance of established social and psychological relationships with other pupils and with teachers....

It is obvious that it would be very difficult, under such a law, to bring about any significant amount of desegregation. ${ }^{45}$ At first courts sustained these kinds of laws, which were constitutional on their face, on the assumption that they were being constitutionally applied. ${ }^{46}$ Finally, however, the courts began to hold that since the initial assignment was on the basis of race, such measures were unconstitutional. ${ }^{47}$

(2) Freedom-of-choice Plans. School authorities began to replace pupil assignment plans with freedom-of-choice plans. Most of these plans required every pupil to exercise a choice at the beginning of each school year, thus eliminating the automatic initial assignment of pupils to the schools of their race unless a transfer were requested. A pupil's choice could only be denied on the basis of overcrowding. However, "freedom-of-choice" plans did not work either. ${ }^{48}$ In 1968, with Green 1 . County School Board, ${ }^{49}$ the Court finally announced that it would no longer permit freedom-of-choice plans where the

43. See Read, supra note 33, for a much more detailed and comprehensive discussion of the kinds of measures to which the states resorted in attempting to demonstrate that they had moved to a "racially nondiscriminatory school system."

44. Ala. Code tits. 52-56, §61(4) (1960).

45. Note, The Federal Courts and Integration of Southern Schools: Troubled Status of the Pupil Placement Acts, 62 Colum. L. Rev. 1448, $1452-53$ (1962).

46. See, e.g., Carson v. Warlick, 238 F.2d 724 (4th Cir. 1956), cert. denied, 353 U.S. 910 (1957); Shuttlesworth v. Birmingham Bd. of Educ., 162 F. Supp. 372 (N.D. Ala. 1958), aff ${ }^{\circ}$ on limited grounds, 358 U.S. $101(1958)$.

47. See, e.g., Bush v. Orleans Parish School Bd., 308 F.2d 491 (1962); Northcross v. Board of Educ., 302 F.2d 818 (6th Cir.), cert. denied, 370 U.S. 944 (1962).

48. United States v. Jefferson County Bd. of Educ., 372 F.2d 836, 888-94 (5th Cir. 1966), aff $d$ on rehearing en banc, 380 F.2d 385 ( 5 th Cir.), cert. denied, 389 U.S. 840 (1967); United States Commission on Civil Rights, Survey of School Desegregation in the Southern and Border STATES $1965-66$, at $51(1966)$.

49. 391 U.S. 430 (1968). 
"freedom" was illusory, and where it produced only token desegregation. ${ }^{50}$ However, it left open the question of what the freedom-of-choice plans it might permit would resemble. ${ }^{51}$

(3) "All Deliberate Speed Plans." These included grade-a-year plans and other proposals which brought about-at best-token desegregation. In 1969, the Court, in a short per curiam opinion, made clear that boards of education would no longer be allowed to desegregate "with all deliberate speed." 52

\section{II}

\section{The Constitutional Violation}

Having ordered massive immediate desegregation, ${ }^{53}$ the unanswered questions that remained were: by what means and up to what limits? What is in the arsenal of equitable remedies which federal judges can draw upon? Are there limits to the use of certain remedies and if so, what are they? The case in which the Supreme Court attempted to come to grips with some of these questions is the now famous Swann v. Charlotte-Mecklenburg County Board of Education, ${ }^{54}$ decided in 1971.

\section{A. District-wide De Jure Segregation}

Until Keyes v. School District No. 1 (the Denver case) ${ }^{55}$ the Supreme Court had only dealt with cases from school districts in which segregation had been

50. New Kent County School Board had made no steps 10 desegregate until 1965 when it adopted its freedom-of-choice plan. Only 15 per cent of the black students and none of the white students had changed schools under the plan. Id. at 441-42.

51. We do not hold that "freedom of choice" can have no place in [a desegregation] plan.

We do not hold that a "freedom-of-choice" plan might of itself be unconstitutional ....

Although the general experience under "freedom of choice" to date has been such as to indicate its ineffectiveness as a tool of desegregation, [footnote omitted] there may well be instances in which it can serve as an effective device. Where it offers real promise of aiding a desegregation program to effectuate conversion of a state-imposed dual system to a unitary, nonracial system there might be no objection to allowing such a device to prove itself in operation. On the other hand, if there are reasonably available other ways, such for illustration as zoning, promising speedier and more effective conversion to a unitary, nonracial school system, "freedom of choice" must be held unacceptable.

391 L.S. at $439.440-41$.

52. Alexander v. Holmes County Bd. of Educ., 396 U.S. 19 (1969).

[T] he Court of Appeals should have denied all motions for additional time because continued operation of segregated schools under a standard of allowing "all deliberate speed" for desegregation is no longer constitutionally permissible.

Id. at 20 (emphasis added). See also Carter v. West Feliciana Parish School Bd., 396 U.S. 290 (1970).

53. In Professor Read's view, while "enormous progress" had been made between Green and Carter, "it was the Carter reversal that precipitated another quantum leap in school desegregation activity." Read, supra note 33, at 32. In Carter, the Fifth Circuit had permitted a delay in implementing court-ordered desegregation plans while cases were being appealed. The Supreme Court summarily reversed, causing a shift from token desegregation to massive affirmative integration. Id.

54. 402 U.S. 1 (1971). Swann's approach to the question of appropriate remedies is discussed in the text at pp. 81-88 infra

55. 413 U.S. 189 (1973). 
required (or at least permitted) by law. Swann is representative of the category of cases in which there was an admitted past history of district-wide de jure segregation. The Court found that the Charlotte-Mecklenburg school board had not yet completely disestablished its dual school system and converted it to the "unitary, nonracial system of public education" dictated by Green ${ }^{56}$ The school board had argued that the segregated pattern of school attendance was not due to deliberate assignment by race on the part of school officials but rather to the nature of residential patterns. In other words, the board argued, since there was no longer a statute requiring segregated schools and no deliberate acts on the part of school officials to segregate the schools, there was no constitutional violation to be remedied. The schools were segregated, but only fortuitously, as a result of the use of neighborhood attendance zones in a school district in which the neighborhoods were highly segregated.

The Court seemed to agree with the school authorities that there was no discrimination practiced by the school district in its present method of assigning pupils. Nevertheless, the Court presumed that there was a causal connection between the school district's admitted past discrimination and the present pattern of segregated schools. This meant that in a system formerly segregated by law, the plaintiff could invoke a presumption that the current segregated patterns were "vestiges" of past state-imposed segregation. ${ }^{57}$ Among the factors the courts would look to is whether past discriminatory conduct of the school board might have contributed to the creation and maintenance of segregated residential patterns which, when coupled with the present use of geographic proximity as a basis for assignment, would produce segregated patterns of student attendance. ${ }^{58}$ For example, prior decisions of the school board regarding location and size of schools might explain why assigning students to schools nearest their homes would result in racially homogeneous schools: a new school is constructed to be of such a size that it can serve only a racially homogeneous area or is so situated that it is the closest school to students of only one race. ${ }^{59}$

56. 391 U.S. at 436 .

57. 402 U.S. at 26.

58. 402 U.S. at 28.

59. Id. The Sutann opinion clearly implies that the location of school facilities can contribute to the development of a pattern of residential segregation as well as the reverse.

People gravitate coward school facilities, just as schools are located in response to the needs of people. The location of schools may thus influence the patterns of residential development of a metropolitan area and have important impact on composition of innercity neighborhoods. . . It may well promote segregated residential patterns which. when combined with "neighborhood zoning." further lock the school system into the mold of separation of the races.

402 U.S. at 20-2 1 .

In a later case-the first school desegregation case outside of the South to be decided by the Supreme Court-the Court referred to the "reciplocal effect" on the racial composition rif residential neighborhoods caused by school assignment and other policies which "earmark" schools according to their racial composition. Keyes $v$. School Dist. No. 1. 413 U.S. 189. $201-02$ (1973). For example, in Denver, a small school was consiructed in the midst of other elementary schools attended predominantly by blacks, all of which were located in the predominantly black section of 
The Court even indicated that plaintiffs could establish a prima facie case of a violation of the equal protection clause without evidence of student assignment policies or of neighborhood residential patterns of segregation when ${ }^{60}$

it is possible to identify a "white school" or a "Negro school" simply by reference to the racial composition of teachers and staff, the quality of school buildings and equipment or the organization of sports activities ....

Thus, what the Court was saying is that in a school district where there is a past history of de jure segregation, it is the effect of decisions made by school officials that is important, and not whether those decisions were made with intent to maintain segregation. ${ }^{61}$

The Court also indicated, however, that at some point in time the relationship between a system's past segregative acts and present segregation may become so attenuated as to be incapable of supporting a finding of de jure segregation warranting judicial intervention. ${ }^{62}$ Consequently, the Court raised, by implication, the question of how long a period of supervision by the courts will be required before they determine whether a dual system has been dismantled. Precisely what a defendant school board must show to overcome the presumption that the segregated pattern is still a "vestige" of previous stateimposed segregation, however, remains unanswered.

Does the Constitution impose on school boards the duty of retarding district-wide resegregation? Resegregation can be caused by changes in residential patterns as a function of "white flight" whether due to "natural mobility" or private bias (e.g., discrimination in the sale, rental or financing of housing in the private market) or to policies and practices of governmental agencies in locating housing, highways and other public facilities, and in developing and maintaining exclusionary land use practices. ${ }^{63}$ Are such changes in residential

the cily. This new school was then used to accommodate the overflow from the nearby black schools, and, although a predominantly-whte elementary school just eight blocks away was also overcrowded. no white students were transferred to the newly built school. For the facts of this situation, see 445 F.2d 990, 1000 (10h Cir. 1971) (same case. lower court opinion).

60. 402 U.S. at 18.

61. "Thus we have focused upon the effect-not the purpose or motivation of a school board's action ...." Wright v. Council of City of Emporia, 407 U.S. 451,462 (1972).

62. 402 U.S. at 31-32. The Court's restatement of the original proposition is in Kryes, 413 U.S. at 211 .

63. In Hart v. Community School Bd., 383 F. Supp. 699 (E.D.N.Y. 1974), a federal district coun took cognizance of the fact that other governmental agencies were responsible, at least in part, for segregated residential patterns. Id. at 758. The court ordered city, state, and federal housing authorities to provide a joint plan for reducing the racial imbalance in the affected neighborhood. Id. at 757. The court suggested that such a plan might include "refertilization" of the area with new white families who would contribute to stabilization; acceleration of housing construction in various parts of the area; and modification of renting and construction patterns to encourage substantial members of white and middle class families with children to move into buildings constructed with the aid of public funds. The police commissioner was ordered to present a plan for adequate protection of children in the vicinity of the school; the Metropolitan Transit Authority was ordered to assist in the planning of adequate transportation to and from the school: and the Commissioner of Recreation was ordered to become involved in planning for the use of the public parks by school children. Id. at 757-58. The judge initially joined as additional parties 
patterns which are not the result of actions taken by school authorities nevertheless their responsibility to correct through school assignment policies once the school authorities have implemented the desegregation plan and disestablished the heretofore dual school system?

The Swann opinion could be read to imply that a school board has no obligation to prevent or retard resegregation once it has "cured" the last vestiges of de jure segregation and established itself as a unitary system. Yet notwithstanding the establishment of a unitary system, there would still be certain factors within the control of school officials that could affect resegregation: the overall quality of the educational offering, curriculum content and enrichment; extracurricular activities; improvement of older facilities; and, in particular, preparation of teachers, students, and the community for the process of desegregation. ${ }^{64}$ This suggests that a school board might at least be required to refrain from those administrative decisions which would precipitate or accelerate resegregation.

\section{B. Segregative Actions of School Officials in a Part of the District}

As the first non-southern school desegregation case to come before the Supreme Court, the Denver case ${ }^{65}$ led to the articulation of the issues involved in a school system that had never been segregated pursuant to state statutory or constitutional provisions. There the Court found that certain actions on the part of school authorities amounted to de jure segregation. ${ }^{66}$ However, the significance of Keyes lies in the manner in which it addressed the fact that while schools throughout Denver were segregated, the segregative actions in this case occurred in only part of the school system. ${ }^{67}$ Nevertheless, the Court found district-wide remedies appropriate.

What was needed to find that the pattern of segregation was a result of the school board's unlawful actions? The difference between de facto and de jure segregation was first clearly articulated by Judge Wisdom of the Fifth Circuit in $1966 .{ }^{68}$ In Swann, ${ }^{69}$ the Supreme Court noted that there was a difference

all government agencies whose programs and policies might have an impact on the stability of a desegregation plan, but later abandoned this approach, noting that "the decretal tool is poorly designed for restructuring an entire community." 383 F. Supp. 769, 775 (E.D.N.Y. 1974), aff'd, 512 F.2d 37 (2d Cir. 1975).

64. See Orfield, How to Make Desegregation Work: The Adaptation of Schools to Their Newly Integrated Student Bodies, 39 Law \& Contemp. Prob. no. 2, at 314 (1975).

65. Keyes v. School Dist. No. 1, 413 U.S. 189 (1973).

66. Id. at 207-08.

67. The Denver School Board was found to have followed a deliberately segregative policy only with respect to schools in the northeastern section of the city, attended by 37.7 per cent of Denver's total black school population. Id. at 199. By contrast, de jure segregation was system-wide in Swann.

68. United States v. Jefferson County Bd. of Educ., 372 F.2d 836, 878-79 n. 92 (5th Cir. 1966). See also Bell v. School City of Gary, 324 F.2d 209 (7th Cir. 1963), cert. denied, 377 U.S. 924 (1964). There is a well-developed body of legal writing on de facto segregation; see, e.g., Goodman, De Facto School Segregation: A Constitutional and Empirical Analysis, 60 CaL. L. Rev. 275 (1972); Fiss, Racial Imbalance in the Public Schools: The Constitutional Concepts, 78 Harv. L. REv. 564 (1965); Wright, Public School Desegregation: Legal Remedies for De Facto Segregation, 70 N.Y.U.L. Rev. 285 (1965).

69. 402 U.S, at 17-18. There, in the context of Title IV of the Civil Rights Act of 1964, the 
between de jure and de facto segregation, but it was not until the Denver case, in 1973, that the Court actually spelled out the distinction: " [T] tiating factor between de jure segregation and so-called de facto segregation . . . is purpose or intent to segregate." 70 Thus the plaintiffs "must prove not only that segregated schooling exists but also that it was brought about or maintained by intentional state action." "71 Among the factors which were relied upon as indicators of "purpose" or "intent" to segregate were:

(1) deliberate segregative acts of pupil assignment 10 schools located in a non-white residential area of the city of Denver;

(2) racial assignment of faculty and staff;

(3) locating a school "with conscious knowledge that it would be a segregated school;" (emphasis added) ${ }^{72}$ and

(4) adopting policies which "have the clear effect of earmarking schools according to their racial composition . . . (emphasis added). ${ }^{73}$

These indicators were found only in a part of the district rather than system-wide. The Court held, however, that if these intentional segregative acts occurred in a "meaningful portion" of the school district, it in some way tainted the entire district sufficiently to trigger a district-wide remedy. ${ }^{74}$ The Court suggested two somewhat related grounds for reaching this conclusion. ${ }^{75}$ First, the Court noted that putting all blacks in one school on the basis of racially drawn attendance zones would necessarily keep other nearby schools all white, even though the white students were assigned on the basis of geographic proximity rather than race. ${ }^{i 6}$ Also past decisions with respect to the location and size of one school could have affected the racial composition of nearby schools: if

Court indicated that "de facto segregation" means the existence of racial imbalance in the schools "but with no showing that [the racial imbalance] was brought about by discriminatory action of state authorities." Id. at 18.

70. 413 U.S. at 208. Several of the justices took sharp issue with this distinction. Justice Douglas contended that all school desegregation is a result of state action. and must therefore be struck down as in violation of the Constitution. 413 U.S. at 215 . Justice Powell argued that it is discriminatory to presume continued segregative intent (twenty years after Broun) in the South and not apply the presumption of segregative intent to segregated school districts in the North. If there is segregation, no matter how caused, the burden should be on the school district to show that the system is actually a unitary, nondiscriminatory system. 413 L.S. at 224.

71. 413 L.S. at 198.

72. 413 U.S. at 201-02 (quoting from district court opinion, 303 F. Supp. at 285 ).

73. 413 U.S. at 202.

74. Justice Rehnquist rejected the majority's "meaningful portion" test. In his view, only in a system where total segregation has been required by statute can a district-wide remedy be imposed. 413 U.S. at 255 . In the absence of such a statute, Justice Rehnquist would seem to require a factual determination on a school-by-school basis as to whether particular minority students were denied equal protection of the law, thus placing a heavy burden of proof on the plaintiffs rather than on the defendant school system. 413 U.S. at $256,263$.

75. See Fiss, School Desegregation: The Uncertain Path of the Law, 4 Philosophr \& Pub. Affairs 3 , $22-25(1974)$.

76. The Court stated:

[I] is obvious that a practice of concentrating Negroes in certain schools by structuring attendance zones or designing "feeder" schools on the basis of race has the reciprocal effect of keeping other nearby schools predominanty white.

413 U.S. at $201 \&$ n. 12 
the board decided that a new school should be a black school in a black area and it is sized to serve only the students in that area, other nearby schools would be white even without deliberately assigning students on the basis of race. ${ }^{77}$

The Denver Court also returned to the theory suggested in Swann-that there can be a linkage between past discrimination on the part of school authorities and the present pattern of residential segregation by race. ${ }^{78} 1 \mathrm{t}$ found that the various segregatory policies used by Denver school authorities tended to "earmark" schools as black or white, ${ }^{79}$

and this, in turn, together with the elements of student assignment and school construction, may have a profound reciprocal effect on the racial composition of residential neighborhoods within a metropolitan area, thereby causing further racial concentration within the schools.

Thus one basis for holding that there was sufficient system-wide de jure desegregation to justify imposing a system-wide remedy was the presumption that deliberate segregative policies in a "meaningful" or "substantial" part of the school system taken in the past had a reciprocal effect on the remainder of the system.

The second, somewhat related ground was: ${ }^{80}$

that a finding of intentionally segregative school board actions in a meaningful portion of a school system ... creates a presumption that other segregated schooling within the system is not adventitious. It establishes . . . a prima facie case of unlawful segregative design on the part of school authorities, and shifts to those authorities the burden of proving that other segregated schools within the system are not also the result of intentionally segregative actions.

Thus, to summarize, the Denver case established the following allocation of the burden of proof for those cases in which segregation has never been mandated by state constitutional or statutory provisions: the plaintiff must first establish that there were (1) intentional segregative acts on the part of school authorities, and (2) that such intentional segregative acts were in a "meaningful" or "substantial" portion of the school system. This establishes a prima facie case that the entire system is unlawfully segregated-therefore requiring a district-wide remedy-either on the presumption that intentional acts in a por-

77. The Court concluded that:

$[\mathrm{T}]$ he practice of building a school ... to a certain size and in a certain location, "with conscious knowledge that it would be a segregated school," . . . has a substantial reciprocal effect on the racial composition of other nearby schools.

413 U.S. at 201-02.

78. See text accompanying note 58, at p. 60 supra. This tends to weaken the rather categorical statement made by Justice Stewart in his concurring opinion in Milliken v. Bradley (Detroit) that residential segregation-particularly that due to the increasing concentration of blacks in the central cities-is "caused by unknown and perhaps unknowable factors . . ." 418 U.S. at 756 n. 2. See also Bradley v. School Bd. (Richmond), 462 F.2d 1058, 1066 (4th Cir. 1972), aff'd by an equally divided Court, 412 U.S. 92 (1973).

79. 413 U.S. at 202.

80. 413 U.S, at 208. 
tion of the school system have had a "profound reciprocal effect" on the rest of the system, or on the presumption that where there are racially imbalanced schools throughout the system, the intentional segregative acts could not have been confined to a sub-area of the district.

The burden of proof at this point shifts to the school authorities. ${ }^{81}$ They can rebut the prima facie case by disproving any segregative intent with respect to the rest of the school district ${ }^{82}$ by showing with sufficient specificity "that segregative intent was not among the factors that motivated their actions." (Emphasis added.) ${ }^{83}$ However, disproving a negative-i.e., requiring school authorities to "bear the burden of explaining actions or conditions which appear to be racially motivated" ${ }^{4}$ - is not an easy task. The Court indicated that there may be cases in which the causal connection could be disproved by school authorities by showing that "the geographical structure of, or the natural boundaries within, a school district [have had] the effect of dividing the district in to separate, identifiable and unrelated units. . ." 85 The Court implied, however, that such cases would be rare. ${ }^{86}$

The school district can also "rebut the prima facie case by showing that its past segregative acts did not create or contribute to the current segregated condition" in the other schools in the district. (Emphasis added.) ${ }^{87}$ The Court made it quite clear, however, that mere "remoteness in time has [no] relevance to the issue of intent." 88 On the other hand, the .Court reaffirmed the dicta in Swann, that there may be "some point in time [when] the relationship between past segregative acts and present segregation may become so attenuated as to be incapable of supporting a finding of de jure segregation warranting judicial intervention." 89 Moreover, where the core city population in a school district has long been predominantly minority, the Court suggested that reliance on a "neighborhood school policy" of pupil assignment could not justify segregated schools where "school authorities have been found to have practiced de jure segregation in a meaningful portion of the school system . . ."90

The difference, then, between Swann and Keyes as to the burden of proof is that in Swann a prima facie case of unconstitutional segregative actions was

\footnotetext{
81. 413 U.S. at 209.

82. 413 U.S. at $210-11$.

83. 413 U.S. at 210.

84. 413 U.S. at 209.

85. 413 U.S. at 203.

86. In Keyes, a six-lane major highway was not considered to be a barrier dividing the district into "separate, identifiable and unrelated units." 413 U.S. at 204-05.

87. 413 U.S. at 211

88. 413 U.S. at 210.

If the actions of school authorities were to any degree motivated by segregative intent and the segregation resulting from those actions continues to exist, the fact of remoteness in time certainly does not make those actions any less "intentional."

413 U.S. at $210-11$.

89. 413 U.S. at 211 (referring to its opinion in Swann, 402 U.S. at 31-32).

90. 413 U.S. at 212 .
} 
established by the existence of racially identifiable schools, since the case arose in a jurisdiction formerly segregated by statute. The burden was upon the school board to refute this prima facie case. In Keyes, on the other hand, where the school system had never been segregated in accordance with statutory or constitutional provisions, the burden fell initially upon the plaintiff to prove that the school authorities had intentionally and purposefully implemented a system of segregated schools in at least part of the district. Once intent was proven by the plaintiff, the burden shifted to the defendant to prove that the segregative patterns found throughout the district did not emanate from the intentional plan to establish a dual school system in that part of the district where intent had been shown. Thus, the school systems in both Swann and Keyes were de jure segregated systems, but establishing this fact would be somewhat more difficult for plaintiffs bringing suit in jurisdictions such as Denver where segregation was never required or permitted by law.

In neither Swann nor Keyes did the Court place any reliance on social science research to support a finding of a constitutional violation. Courts generally have not inquired whether segregation is psychologically or educationally harmful to black and/or white children, nor have they inquired whether desegregation would "benefit" children in terms of improved pupil performance or ability to compete in the marketplace. In Swann, the Court reaffirmed the principle of Brown that "[s]eparate educational facilities are inherently unequal." 91 (Emphasis added.) It would seem, therefore, that although the question of educational harms and benefits may be relevant to the nature and extent of the remedies which may be used, it is irrelevant to the determination of a violation of the equal protection clause. The only social science evidence usually introduced in such suits is extensive empirical evidence concerning residential segregation patterns and other demographic trends.

\section{Segregated Pattern Resulting From Actions of}

School Authorities Without Apparent Segregative Intent

The Supreme Court has not yet been confronted with a case in which a segregated pattern has resulted from actions taken by school officials in all or a portion of a school district, with no apparent segregative purpose or intent as the Court found in the Denver case. In both Swann and Keyes, the Court attempted to find a linkage between the existence of a segregated pattern of schooling and deliberate assignment on the basis of race. Since in those cases the Court was unable to find that the present pattern of segregated schools resulted from present deliberate segregative acts of school authorities, the Court permitted the plaintiffs to show that such intentional segregative acts were undertaken in the past. ${ }^{92}$ The Court, in Keyes, further held that the past discriminatory acts of school authorities need only have been in a portion of the

91. 402 L.S. at 11.

92. Sep Fiss, supra note 75 , at 25. 
school district rather than system-wide. This approach, however, stops short of saying that racial imbalance alone is a violation of the equal protection clause. ${ }^{93}$

What must a plaintiff show to establish a prima facie case of de jure segregation where there has been no history of statutorily imposed segregation? Keyes clearly says that plaintiffs must show that the segregated schooling that exists "was brought about or maintained by intentional state action." 94 If, however, there is no direct evidence of intent (in resolutions or minutes of board meetings, in the assignment of faculty and staff, or even in site selection for the construction of new schools) and the school district simply has a neighborhood schools policy of student assignment superimposed on a segregated residential pattern which itself is not the result of any actions on the part of the school authorities, is this sufficient to establish "segregative intent"? May segregative intent be inferred from school board actions which have the foreseeable effect of fostering segregation? ${ }^{95}$ Have courts engrafted the tort principle-that a person is responsible for the natural consequences of his actions-onto school desegregation cases in order to establish "intent"? 996

The Second Circuit has taken the position that specific racial motive need not be shown to underlie the actions of school authorities-that intentional action leading foreseeably to discrimination, but taken without racial motivation also constitutes de jure segregation. ${ }^{97}$ The court did note, however, that the standard by which state action is to be judged "has not been settled authoritatively by the Supreme Court." 98 Thus, until the Supreme Court says otherwise, the standard which the Second Circuit will apply is as follows: ${ }^{99}$

[A] finding of de jure segregation may be based on actions taken, coupled with omissions made, by governmental authorities which have the natural and foreseeable consequence of causing educational segregation.

A federal district court in Michigan, in holding that the board of education in Kalamazoo had followed a purposeful pattern of racial discrimination by intentional acts of commission or omission, ${ }^{100}$ applied general principles of tort

93. Professor Fiss suggests, however, that the nature and extent of the remedy in Keyes-and indeed, even in Swann-"can be explained only if the segregation itself is viewed as the evil and the past discrimination is viewed as the triggering mechanism." Id. at 26.

94. 413 U.S. at 198 .

95. Note that one of the factors indicating "intent" in the Denver case is the location of schools "with conscious knowledge" that they will be segregated. 413 U.S. at 201-02.

96. Cf. Monroe v. Pape, 365 U.S. 167 (1961). In this 1961 decision, the Supreme Court, in delimiting the elements of a civil cause of action under 42 U.S.C. $\$ 1983$ (1970) (imposing civil liability upon "[e]very person who, under color of any statute . . of any State . . subjects . . any citizen of the United States... to the deprivation of any rights . . . secured by the Constitution ...."), refused to include "specific intent" as a necessary element, ruling that $\$ 1983$ "should be read against the background of tort liability that makes a man responsible for the natural consequences of his actions." 365 U.S. at 187. See Note, School Desegregaton After Swann: A Theory of Governmental Responsibility, 39 U. CHI. L. REv. 421 (1972).

97. Hart v. Community School Bd. of Educ., 512 F.2d 37, 50 (2d Cir. 1975).

98. 512 F.2d at 49 .

99. 512 F.2d at 50 .

100. Oliver v. Kalamazoo Bd. of Educ. 368 F. Supp. 143 (W.D. Mich. 1973). The court found 
law in determining whether there had been a violation: "[I]t is reasonable to infer that people intend the natural and probable consequences of acts knowingly done or knowingly omitted." ${ }^{101}$ The Sixth Circuit agreed:102

A presumption of segregative purpose arises when plaintiffs establish that the natural, probable, and foreseeable result of public officials' action or inaction was an increase or perpetuation of public school segregation. The presumption becomes proof unless defendants affirmatively establish that their action or inaction was a consistent and resolute application of racially neutral policies.

Plaintiffs in Grand Rapids, Michigan attempted to argue that if there was reason to believe that school board policies could result in segregated schooling, there was an affirmative duty to change such policies for those which would eliminate racial imbalance. ${ }^{103}$ The plaintiffs in that case asserted that ${ }^{104}$

the school board had sufficient knowledge and forewarning that continued operation of a neighborhood school system would result in imbalanced schools and that this alone was enough to place on [the school board] the affirmative duty to take action to eliminate such imbalance.

The Sixth Circuit noted, however, that ${ }^{105}$

the phenomenal increase in the black population in Grand Rapids was not clearly foreseeable until the imbalances were so advanced that a far-reaching reshuffling would have been required to correct them.

But the implication is that school officials would have been responsible for correcting racial imbalances in the schools had the residential patterns been foreseeable.

One commentator has recently pointed out that the evidence in the Kalamazoo and Grand Rapids cases was quite similar, yet one district court found that there was a purposeful pattern of racial discrimination and the other court found none. ${ }^{106}$ The Sixth Circuit upheld both cases. The Sixth Circuit, in its opinion in the Grand Rapids case, indicated that the fact that the Kalamazoo School Board had rescinded a desegregation plan after candidates

the failure to develop or implement

any policy designed to positively confront the problem of racial isolation in the Kalamazoo public schools ... was itself a deliberate decision to forego [the] opportunity to correct the existing segregated conditions and itself was an unconstitutional denial of equal protection of the laws.

Id. at 178-79.

101. 368 F. Supp. at 161 .

102. Oliver v. Michigan State Bd. of Educ., 508 F.2d 178, $181-82$ (6th Cir. 1974). Accord, Morgan v. Kerrigan, 509 F.2d 580, 588-89 (1st Cir. 1974); Cisneros v. Corpus Christi Independent School Dist., 467 F.2d 142, 149 (5th Cir. 1972), cert. denied, 413 U.S. 920 (1973); United States v. Texas Educ. Agency, 467 F.2d 848, 863 (5th Cir. 1972). But see Johnson v. San Francisco Unified School Dist., 500 F.2d 349, 351-52 (9th Cir. 1974); Soria v. Oxnard School Dist., 488 F.2d 579, 585,588 (9th Cir. 1973), cert. denied, 416 U.S. 951 (1974).

103. Higgins v. Board of Educ., 508 F.2d 779 (6th Cir. 1974).

104. Id. at $789-90$.

105. Id. at 790 .

106. Marshall, The Standard of Intent: Two Recent Michigan Cases, 4 J. LAw \& ED. 227 (1975). 
opposed to desegregation were elected to the board, distinguished Kalamazoo from Grand Rapids. ${ }^{107}$ This suggests that the Sixth Circuit might require more specific actions indicating segregative intent than the Second Circuit.

\section{Segregation Not Attributable to School Board Policies: The De Facto Dilemma}

Both the district and the circuit courts in the Denver case found de jure segregation in only a portion of the school district. The separation of the races in the rest of the school district was treated as de facto segregation. ${ }^{108}$ Thus the Supreme Court could have used that case as a vehicle for determining whether the equal protection clause imposes upon the school board an affirmative duty to correct de facto segregation or racial imbalance in the schools that results solely from segregated residential patterns. Instead the Supreme Court found de jure segregation in a part of the district and extrapolated that to the entire system. Thus the Supreme Court has yet to review a case of "pure" racial imbalance or de facto segregation. ${ }^{109}$ Nevertheless, with the Keyes case, desegregation could no longer be said to be exclusively a southern problem-de jure, in other words, means state actions and policies of various kinds which result in segregated schools, not just compelled separation by statute or constitution. A purely de facto segregated school district, then, would be one in which there was neither a history of statutorily-imposed segregation nor intentional segregative acts on the part of school officials. The racial imbalance in the schools is fortuitous, attributed solely to a neighborhood schools policy superimposed on a pattern of residential segregation. ${ }^{110}$

Some commentators and even some courts have suggested that neighborhood schooling coupled with private discrimination should, without more, be sufficient to establish a violation of the equal protection clause. ${ }^{11}$ One commentator states the argument as follows: ${ }^{12}$

Residence in the ghetto, and thus membership in the class disadvantaged by the neighborhood [school] assignment policy, is often the immediate conse-

107. 508 F.2d at 791 .

108. 313 F. Supp. 51, 83 (D. Colo. 1970), aff'd, 445 F.2d 990 (10th Cir. 1971).

109. The next major desegregation case to come before the Court was Milliken v. Bradley, 418 U.S. 717 (1974). There the Court upheld the district court's finding that the racial imbalance within Detroit was clearly de jure.

110. The Keyes majority noted that the case had not presented the Court with an "occasion to consider ... whether a 'neighborhood school policy' of itself will justify racial ethnic concentrations in the absence of a finding that school authorities have committed acts constituting de jure segregation." 413 U.S. at 212.

111. See, e.g., United States v. Texas Educ. Agency, 467 F.2d 848, 863-64 n. 22 (5th Cir. 1972) (emphasis added):

Whether or not the residential isolation of whites, blacks, and Mexican-Americans in Austin is ... the result of state action, the acts of the school authorities in taking official action, including assigning students ... and drawing zone lines, on the basis of these segregated housing patterns were violative of the fourteenth amendment.

112. Goodman, supra note 68 , at 320 . 
quence of racially discriminatory practices in the housing market. Where race directly determines place-of-residence, grouping students in school by placeof-residence becomes, in effect, racial classification once-removed. It amplifies the consequences of private discrimination; it lengthens the discriminator's arm, giving him a veto over admission to the neighborhood public school.

It has also been suggested that in such a case the Court could look to actions of other governmental agencies which may have contributed to the pattern of residential segregation in order to find that the pattern of segregated schooling constitutes de jure segregation. The question of the effect of such actions was expressly reserved for future decision in Swann $;^{113}$ likewise, in the Denver case the opinion was confined to actions by the school board alone. ${ }^{114}$ If the actions of other government officials are alleged to have caused the patterns of residential segregation, should they be parties to the school desegregation suit? ${ }^{115}$ If not, must the school board bear the burden of proving that there was no segregative intent on the part of these other governmental agencies or that past segregative acts by these other agencies did not contribute to the present pattern of segregated public schools?

Assuming that plaintiffs could prove that intentional actions by other governmental agencies had caused residential segregation, what then is the duty of the school board? Could the Court hold the school board responsible for desegregation of the schools because the racial imbalance could have been reasonably prevented and the board had failed to adopt a "reasonably feasible" alternative which would have reduced the imbalance? In other words, does the fourteenth amendment require affirmative action by the school board to prevent or reduce racial imbalance regardless of the cause?

It is unclear whether the Court would find that school authorities had an affirmative duty to correct de facto racial imbalance in view of the Court's attempt in the Denver case to articulate the distinction between de jure and de facto school segregation: "the differentiating factor between de jure segregation and so-called de facto segregation to which we referred in Swann is purpose or intent to segregate."116 The necessary implication is that this distinction must be of constitutional significance.

State courts and lower federal courts have rushed to apply the de facto/de

113. 402 U.S. at 23

114. 413 U.S. at 191 .

115. In Hart v. Community School Bd., 383 F. Supp. 699 (E.D.N.Y. 1974), the school board impleaded city, state, and federal housing and urban development agencies on the theory that they had fostered residential segregation which resulted in school segregation. But see. United States v. Texas Educ. Agency, 467 F.2d 848, 864 n. 22 (5th Cir. 1972) to the effect that the school authorities might still be liable for the segregated schools: "When the segregated housing patterns are the result of "state action" [and the school board uses a neighborhood schools policy of student assignment], we are faced with double discrimination."

The court in Hart required the other non-school agencies to participate in the relief; however, the claims of the school board against these other governmental agencies were later recommended dismissed. 512 F.2d 37, 56 (2d Cir. 1975).

116. 413 U.S. at 208. 
jure distinction articulated in Keyes. In Los Angeles, a trial court ruling in favor of plaintiffs in a school desegregation case which has been in the courts for twelve years was reversed by a California court of appeals. ${ }^{117}$ Five years earlier in that case, the trial judge, after a nine month trial, found that the school district, in selecting school sites and in using neighborhood school assignments coupled with restrictive transfer policies, had promoted segregated schooling. The appellate court, however, was unable to find anything in the school district's acts or omissions which demonstrated "purpose or intent" to segregate. The most that the record of the trial proceedings would establish, the appellate court maintained, was inaction rather than actions which were intentionally segregative. ${ }^{118}$

If a case involving a purely de facto segregated school system came before the Supreme Court, would it be found constitutional per se or can there ever be an affirmative constitutional duty upon the school board to lessen racial imbalance? Obviously, for an affirmative duty to arise, it would have to be shown that de facto segregation is a violation of the equal protection clause. Conceivably, to find that the constitutional rights of black students are being impinged, the de facto racial imbalance would have to be shown to be educationally or psychologically harmful. Thus while proof of harm is not relevant in a de jure situation-unless Brown is to be relitigated, ${ }^{119}$ the Supreme Court's articulation of the dichotomy between de jure and de facto segregation suggests that an affirmative duty to overcome pure de facto segregation ${ }^{120}$ might have to be based on a showing that de facto segregation inflicted the same educational harm as the statutorily-imposed segregation outlawed in Brown.

A district court in New York recently has come to such a conclusion, relying on social science data to support its finding of "harm" from non-state-imposed segregation. ${ }^{121}$ Similarly, the district court in the Denver case, although con-

117. Crawford v. Board of Educ., Cal. App. 3d 120 Cal, Rptr. 334 (1975).

118. Id. at 338 .

119. See Stell v. Savannah-Chatham County Bd. of Educ., 333 F.2d 55, 61 (5th Cir.), cert. denied, 379 U.S. 933 (1964).

120. If pure de facto segregation is defined as that arising solely from residential segregation that is attributable neither to policies of school authorities nor of other governmental agencies, the number of city school districts found to be de facto segregated should be very few-if indeed one exists at all.

121. Hart v. Community School Bd., 383 F. Supp. 699, 728-37 (E.D.N.Y. 1974). Among the studies cited were the U.S. Civil Rights Commission's Report, Racial Isolation in the Public Schools, the National Advisory Commission's Report on Civil Disorders, and the Fleischmann Commission's Report on the Quality, Cost, and Financing of Elementary and Secondary Education in New York State. $I d$.

It should be noted, however, that the district judge first concluded that racially segregated schools violate the equal protection clause absent statutory compulsion and even absent a finding of "unlawful segregative design." 383 F. Supp. at 739. According to Judge Weinstein, that conclusion is supported by "reason and authority," including Blocker v, Board of Educ., 226 F. Supp. 208 (E.D.N.Y. 1964) (where the finding that 100 per cent of the district's black students attended a disproportionately small school with only one per cent of the district's white students-coupled with a rigid no-transfer policy-constituted "state-imposed" segregation); Fiss, Racial Imbalance in the Public Schools: The Constitutional Concepts, 78 HARv. L. REv. 564 (1965); Fiss, The Charlotte- 
cluding that there was no duty to desegregate the core because there was no finding of district-wide de jure segregation, ${ }^{122}$ nevertheless found that "an equal educational opportunity [was] not being provided at the subject segregated schools within the District . . ." ${ }^{123}$ The only remedy for that situation was desegregation of the minority-race schools. ${ }^{124}$ In arriving at this conclusion, the court relied on testimony that a racially integrated setting is critically important to improving the quality of educational opportunity. Among those who testified were James Coleman (author of the Coleman Report), Neil Sullivan (then Commissioner of the Massachusetts State Board of Education and previously Superintendent of the Berkeley School District when that system desegregated), and Robert O'Reilly (then assistant director of research and evaluation for the New York State Department of Education). ${ }^{125}$

The judiciary-and others ${ }^{126}$ - have not wholly embraced the argument that, regardless of the method of pupil assignment used, segregation stigmatizes blacks and deprives them of an educational opportunity equal to that which could be assured by contact with middle class white students. The courts' reluctance is probably due to the uncertainty surrounding the question of whether a segregated pattern of schooling itself means inferior education for blacks; this uncertainty persists not in spite of, but because of, the present state of social science research. A number of black parents and community groups are also beginning to question whether continued efforts to desegregate public schools is the most effective strategy available for improving the quality of education for their children. ${ }^{127}$

Mecklenburg Case-Its Significance for Northern School Desegregation, 38 U. CHI. L. REv. 697 (1971); and Goodman, supra note 68. 383 F. Supp. at 728-35.

122. Keyes v. School Dist. No. 1, 313 F. Supp. 61, 73-77 (D. Colo. 1970).

123. 313 F. Supp. at 83.

124. 313 F. Supp. 90, 96. The Tenth Circuit reversed the district court on this point, noting that equal educational opportunity constitutionally requires only that the state refrain from intentionally segregating by race. 445 F.2d 990, 1004-06 (10th Cir. 1971).

125. 313 F. Supp. at 94-97. Professor Coleman had testified that a school fails to provide equal educational opportunity when its student body is drawn largely from lower socioeconomic groups. See Yudof, Equal Educational Opportunity and the Courts, 51 Tex. L. Rev. 41 1, 442-43 (1973) for an excellent analysis of this aspect of the Keyes decision. Professor Yudof suggests that the court's conclusion-based on the lower achievement scores of blacks-that they must be brought into contact "with classroom associates who can contribute to the learning process," $313 \mathrm{~F}$. Supp. at 96-97, is faulty inasmuch as Professor Coleman speaks to socioeconomic integration and not racial integration. Professor Yudof also notes that resting the case for desegregation on improved achievement scores could serve to undercut reform if at some future date it were shown that socioeconomic or racial integration failed to raise test scores. Yudof, supra at 443. Cf. Cahn, supra note 20 .

126. See, e.g., Bell, Waiting on the Promise of Brown, 39 Law \& Contemp. Prob. no. 2, at 341 (1975).

127. Id.; Comment, Alternative Schools for Minority Students: The Constitution, the Civil Rights Act and the Berkeley Experiment, 61 CALIF. L. Rev. 858 (1973). See also comments by Rev. Ralph Abernathy and other black community leaders in Cose, $D r$. King's Protest Rose from Desegregation Conflict, The Chapel Hill Newspaper, June 13, 1975, $\S$ A, at 6. See Yudof, supra note 125, at 471. But cf. Hart v. Community School Bd., 383 F. Supp. 699, 742.(E.D.N.Y. 1974), in which the court rejected the argument that self-imposed segregation in public schools was desirable or constitutional. The 
If, in the Denver case, David Armor, ${ }^{128}$ Barbara Sizemore, ${ }^{129}$ Roy Innis, ${ }^{130}$ or Ronald Edmonds ${ }^{131}$ had testified instead of Coleman, ${ }^{132}$ Sullivan, and O'Reilly, would (or should) the result have been different? In other words, does an affirmative duty to correct de facto racial imbalance arise only when the evidence shows that "equal educational opportunity" can only be guaranteed to minority children by desegregation? The district court in the Detroit case raised the question whether educational theory and research-"from the Coleman report to its many reanalyses"- - on the effects of desegregation on pupil achievement versus increased resource inputs, could "form the basis for requiring judicial intervention and relief in the absence of a finding of de jure segregation ....".133 Judge Roth noted, however, that such evidence is totally beside the point when school segregation is caused in substantial part by governmental action. ${ }^{134}$

Several cases where courts have found school segregation to be de facto rather than de jure suggest that, under certain circumstances, a school district is nonetheless legally obligated to correct racial imbalance. In People v. San Diego Unified School District, ${ }^{135}$ the principle was stated as follows: ${ }^{136}$

[S]chool authorities in California have a constitutional duty to "take steps, insofar as reasonably feasible, to alleviate racial imbalance in schools regardless of its cause" where the imbalance denies the minority group equal educational opportunities .... The action of school authorities in maintaining de facto racially imbalanced public schools is not a denial of equal protection of the law unless the imbalance denies the minority group equal educational opportunities. . . In each case seeking relief from such imbalance the court must determine whether the imbalance is of such a degree [that] it affects the educational opportunities of the minority group; whether, under the circumstances, the minority group, in fact, is denied equal educational opportunities; and whether available steps to alleviate the imbalance are reasonably feasible in light of the degree of the imbalance and the practical necessities of governmental operation.

judge relied on several articles opposed to self-segregation: Allen, The Politics of Urban Education, in Black Manifesto for Education 47 (J. Haskins ed. 1973); Clark, Issues in Urban Education, in Black Manifesto for Education 74 (J. Haskins ed. 1973); W.E.B. DuBois, The Crisis Writings (1972). See also studies cited by the district judge on the harmful effects of segregation, supra note 121 .

128. Armor, The Evidence on Busing, 28 Pub. INTERest 90 (Summer 1972).

129. Sizemore, Is There a Case for Separate Schools?, 53 Phi Delta Kappan 281 (1972); Sizemore, Education for Liberation, 81 SCHOOL. Rev. 389 (1973).

130. Rising Black Clamor for Black Separatism, U.S. News \& World Report, Sept. 21, 1970, at 82.

131. Edmonds, Judicial Assumptions on the Value of Integrated Education for Blacks, in D. BELL, Race, Racism and American Law 592 (1973).

132. While Dr. James S. Coleman has testified in numerous school desegregation suits as to the beneficial effects of racial, and particularly, class integration, and the Coleman Report has been cited in countless more cases in support of desegregation, he has recently cast doubt on the merits of court-ordered desegregation. J. Coleman, Recent Trends in School Integration, Apr. 2, 1975 (paper presented at American Educational Research Association).

133. Bradley v. Milliken, 345 F. Supp. 914, 921-22 n. 1 (E.D. Mich. 1972).

134. Id.

135. 19 Cal. App. 3d 252, 96 Cal. Rptr. 658 (1971), cert. denied, 405 U.S. 1016 (1972).

136. Id. at 265-66, 96 Cal Rptr. at 666 . 


\section{E. Language Exclusion: A Constitutional Violation?}

A somewhat different problem to be considered with those cases concerning constitutional violations rather than remedies is the "functional exclusion" from education of ethnic minorities whose native language is not English. There are several million such school-age children. Of these, at least three million have so little proficiency in English that they cannot benefit from regular classes. ${ }^{137}$ The failure of the San Francisco school system to overcome the language deficiencies of some of its students was challenged in a recent law suit. That case involved 2,856 Chinese-American students who were compelled to attend schools where subjects were taught only in English-a language they could not understand. The plaintiffs claimed that the school authorities had denied those students an equal educational opportunity in contravention to the equal protection clause. The Ninth Circuit held that in the absence of a finding of past or present de jure segregation or of other state actions contributing to the English language deficiencies suffered by the Chinese-American students, these claims could not be upheld. ${ }^{138}$ The court found that ${ }^{134}$

[e]very student brings to the starting line of his educational career different advantages and disadiantages caused in part by social, economic and cultural background, created and continued completely apart from any contribution by the school system. That some of these may be impediments which can be orercome [by compensatory education] does not amount to a 'denial' . . of educational opportunity within the meaning of the Fourteenth Amendment should the [school authorities] fail to give them special attention. this even though they are characteristic of a particular ethnic group.

The court also expressed the view that even if a violation of the fourteenth amendment were found, the judiciary should play only a very limited role in shaping the ultimate educational remedy. ${ }^{140}$

$[T]$ he determination of what special educational difficulties faced by some students . . will be afforded extraordinary curative action, and the intensity of the measures to be taken, is a complex decision, calling for significant amounts of executive and legislative expertise and non-judicial value judyments. . . The courts should not be called upon to make pedagogic judgments.

The Supreme Court reversed, but only on the ground that school officials had violated $\S 601$ of the Civil Rights Act of $1964,{ }^{141}$ which forbids the denial to any person, on the basis of race, color or national origin, of the benefits of any program receiving federal financial assistance. ${ }^{142}$ The Court also cited

137. Hearings on H.R. 9840 and H.R. 10224 Before the General Subcomm. on Education of the House Comm. on Education and Labor, 90th Cong., Ist Sess. 7 (1967).

138. Lau v. Nichols, 483 F.2d 791 (9th Cir. 1973), rev'd on other grounds. 414 U.S. 563 (1974).

139. Id. at 797 .

140. 483 F.2d at 799 \& $n .17$

141. 42 U.S.C. $\$ 2000 d$ (I970).

142. 414 U.S. at 566-69. 
HEW guidelines promulgated under the Civil Rights $\mathrm{Act}^{143}$ which provide specifically that ${ }^{144}$

[w] here inability to speak and understand the English language excludes national origin-minority children from effective participation in the educational program offered by a school district the district must take affirmative steps to rectify the language deficiency in order 10 open its instructional program to these students.

The Court reserved judgment on the equal protection argument, ${ }^{145}$ however, apparently leaving intact the legal conclusion of the court of appeals that there was no constitutional right to bilingual education. Also, since the Supreme Court ordered nothing more specific than "appropriate relief," 146 presumably the Ninth Circuit will adhere to its original policy and accordingly limit its role in fashioning a remedy.

In Serna v. Portales Municipal Schools, ${ }^{147}$ the district court held that the school authorities' failure to establish a meaningful bilingual educational program in itself constituted a denial of equal education to Chicano students, and a violation of the equal protection clause. ${ }^{148}$ The finding of inequality was based on the results of $1 Q$ and language expression tests administered to first and fifth grade students and the testimony of an educational psychologist that language difficulties accounted for 80 per cent of the achievement difference between Anglo and Chicano children. ${ }^{149}$

In arriving at its legal conclusion that the school authorities had a duty to administer bilingual education, the district court rejected the defendants' argument that the language deficiencies were not the result of any state action. ${ }^{150}$ The Tenth Circuit, on appeal, affirmed the holding of the district court, ${ }^{151}$ but sidestepped the equal protection issue by holding that the Supreme Court's decision in Lau $\%$. Nichols ${ }^{152}$ controlled and that the Portales school system was in violation of $\S 601$ of the 1964 Civil Rights Act. ${ }^{153}$

Of little legal consequence, but of tremendous practical import is the recent consent decree in Aspira of New York, Inc. v. Board of Education, ${ }^{154}$ in which the defendants acknowledged the rights of the plaintiff children under the 1964 Civil Rights Act, citing Lau v. Nichols, and agreed to implement a bilingual-

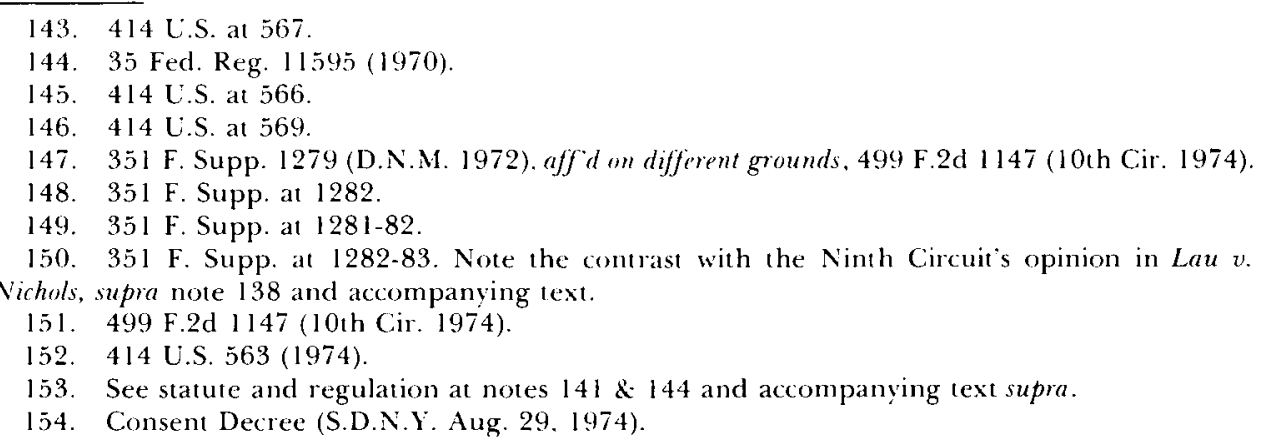


bicultural program of education for "all New York City public school children whose English language deficiency prevents them from effectively participating in the learning process and who can more effectively participate in Spanish."155 If the Aspira consent decree is any indication of the future, it may well be that the Lau decision will become the rock upon which bilingual public education is founded even though the constitutional issue was never decided.

These three cases-Lau v. Nichols, Serna and Aspira-indicate that courts may be abandoning the xenophobic "melting pot" view of America, in which ethnic minorities must become assimilated to white Anglo-Saxon values, language and culture. The thrust of these cases is away from the idea many school administrators have had that the language barrier was a problem which the student had to overcome, and toward the idea that the schools must adapt to meet the differing needs of their pupils.

\section{F. The Segregation of Hispano-Americans: Proving the Violation}

Most of the case law of school desegregation was spawned by the unconstitutional discrimination against blacks in the deep South or the southern border states. Understandably, therefore, most of the cases referred to in this article measure the treatment and experience of blacks in public education vis-à-vis whites. It must be understood, however, that the benefits of the equal protection clause are guaranteed to all identifiable racial or ethnic minorities. The largest identifiable minority, other than blacks, who have asserted their rights under the fourteenth amendment are Hispano-Americans. ${ }^{156}$ The segregation of Hispano-Americans by school district and by schools within districts has been well documented. ${ }^{157}$ Nevertheless, only a small percentage of desegregation cases have involved such students, and most of these are in the Southwest. Many of the problems confronting Hispano-Americans in their attempts to litigate equal educational opportunity are quite similar to those raised in the context of segregated schooling for blacks, but there are also certain very important differences both as to determining the constitutional violation and as to special remedies. ${ }^{158}$

\footnotetext{
155. Id. at 4 .

156. Hispano-Americans are the second largest minority group in the public schools, constituting about 5 per cent of the total population in the nation. U.S. Commission on Civil Rights, Mexican American Education Study, Report I: Ethnic isolation of Mexican Americans in the Public Schools of the Southwest (1971). The term Hispano-American is used to cover both Mexican-Americans and Puerto Ricans. Cubans and other Latin Americans are also included in the term Hispano-American but most of the litigation covers the first two groups. Seventy per cent of the Hispano-Americans, almost all of whom are Mexican-American, attend school in five southwestern stares. $I d$. at 59 . Another minority currently seeking equal educational opportunity is the Native American, but since Indian education litigation presents some unique factors, discrimination against Native American students will not be dealt with in this article.

157. U.S. Commission on Civil Rights, supra note 156.

158. The remedies sought by Hispano-Americans are discussed in the text at pp. 114-20 infra.
} 


\section{Are Hispano-Americans an Especially Protected Minority?}

The first question, in determining whether the isolation of HispanoAmericans is a violation of the equal protection clause, is whether they are a minority which should be legally treated in the same manner as blacks. The first case to hold that Brown applies to Hispano-Americans as well as blacks was Cisneros v. Corpus Christi Independent School District. ${ }^{159}$ Cisneros found that the Mexican-American students in Corpus Christi were segregated ${ }^{160}$ and that "placing Negroes and Mexican-Americans in the same school does not achieve a unitary system as contemplated by law." 161

In the Denver case the district court also found that Hispano-Americans constituted an identifiable ethnic minority entitled to the benefits of the equal protection clause but, because of their different ethnic origins, would not "lump [Negroes and Hispanos] into a single minority category" in order to determine the segregated character of a school. ${ }^{162}$ The Tenth Circuit approved this classification. ${ }^{163}$

The Supreme Court held, however, that "the District Court erred in separating Negroes and Hispanos for purposes of defining a segregated school." 164 The Keyes majority noted that ${ }^{165}$

though of different origins, Negroes and Hispanos in Denver suffer identical discrimination in treatment when compared with the treatment afforded Anglo students. In that circumstance we think [plaintiffs] are entitled to have schools with a combined predominance of Negroes and Hispanos included in the category of "segregated" schools.

In support for its holding, the Court cited a report published by the United States Commission on Civil Rights which found that in certain areas of the Southwest, Hispanos suffer from the same educational inequities as blacks. ${ }^{166}$

The cases following Keyes have treated Hispano discrimination in the same manner as discrimination against blacks and, in tri-ethnic areas as in the Denver case, the degree of segregation in any given school will depend in a great many cases on the ratio of whites to the combined number of identifiable minority in that school.

159. 324 F. Supp. 599, 604-06 (1970). See Note, Project Report: De Jure Segregation of Chicanos in Texas Schools, 7 Harv. Civ. Rights-Civ. Lib. L. Rev. 307, 349 (1972).

160. 324 F. Supp. at 608 .

161. 324 F. Supp. at 616 .

162. Keyes v. School Dist. No. 1, 313 F. Supp. 61, 69 (D. Colo. 1970).

163. 445 F.2d 990, 1006 (10th Cir. 1971).

164. 413 U.S. 189,197 (1973).

165. 413 U.S. at 198.

166. 413 U.S. at 197 n. 8. To support its finding that "Hispanos constitute an identifiable class for purposes of the Fourteenth Amendment," the Court cited Hernandez v. Texas, 347 U.S. 475 (1954), a case which dealt with the exclusion of Hispano-Americans from jury service in Texas in which the Court required that the plaintiff factually establish that the racial group existed within the community in order to qualify for special fourteenth amendment protection. 347 U.S. at 478. Once that fact was established, the group was given the same protection afforded to Negroes in Strauder v. West Virginia, 100 U.S. 303 (1880). 


\section{Proof of Violation}

In Swann, the Court indicated that a prima facie case of unlawful segregation is established if it can be shown that there is segregation in fact and that the formerly dual school system has not yet been disestablished, the pattern of segregated schooling being presumed to be a "vestige" of the previously unlawful, state-imposed segregation. The burden is then shifted to the state to show that the system is now completely unitary and that the segregation that exists is not a "vestige" of the unlawful dual system, but arose fortuitously (through shifting residential patterns) after the system had become unitary.

However, in cases involving Hispanos, the lower federal courts seem to be applying the standard enunciated in the Denver case which places a heavier burden upon the plaintiff attempting to make a prima facie case of unlawful segregation. In Keyes, a finding of unlawful segregation was based upon proof of the school board's intentional segregative acts in a substantial ("meaningful") portion of the school district. The Hispanic plaintiff, then, in order to make a prima facie case of unlawful segregation, must show that segregated schools exist in fact and that their existence is attributable to some intentional action on the part of school authorities or other state officials. The use of the Keyes standard where there was no history of statutorily-imposed segregation is due to the fact that many of the states which required the segregation of blacks and whites-either by statutory or constitutional provisions or both-did not have a similar statutory history toward Hispanos. ${ }^{167}$ Nevertheless, courts have found a

167. For example, TEx. CoNst. art. $7, \S 7$ (1876) required that "[s]eparate schools shall be provided for the white and colored children, and impartial provision shall be made for both." Similarly, in 1905-as part of a bill aimed at improving the public school system-the legislature provided that " $[w]$ hite and colored children shall not be taught in the same schools .... The terms 'colored race' and 'colored children' as used in the preceding articles, and elsewhere in this title, include all persons of mixed blood descended from negro ancestry." Ch, 124, $\$$ 93 \& 96, [1905] Gen. Laws of Texas 263. Both this proviso and art. $7, \S 7$ of the Constitution were repealed at the 1969 legislative session.

In 1930 when Mexican-Americans first challenged separate schools in Texas, the Texas Court of Civil Appeals mentioned cursorily that the Mexican race was one of the several white races and ruled that they could not be segregated solely because they were Mexicans. It was not discriminatory, however, to assign all first through third grade Mexican children to separate schools if, in the opinion of local school authorities, it was in their best interests in order to remedy their language difficulties. Independent School Dist. v. Salvatierra, 33 S.W. 2d 790, 795 (Tex. Civ. App. 1930) appealed dismissed and cert. denied, 284 U.S. 580 (1931). It is interesting to note that while the Salvatierra court permitted separate Mexican schools in order to remedy language handicaps, Texas statutes proscribed the remedial use of Spanish by teachers. Indeed, until quite recently, a teacher who used Spanish to teach Mexican-American children-except in an approved language curriculum-risked criminal conviction:

[E]very teacher ... employed in the public free schools of this state shall use the English language exclusively in the conduct of the work of the schools, and all recitations and exercises of the school shall be conducted in the English language, and the trustees shall not prescribe any texts for elementary grades not printed in the English language . ... Any teacher ... failing to comply with this provision of the law shall be deemed guilty of a misdemeanor and upon conviction thereof in proper court shall be subject to fine of not less than Twenty-five Dollars $(\$ 25.00)$ and not more than One Hundred Dollars $(\$ 100.00)$, cancellation of certificate, . . or both fine and cancellation of certificate ... .

Ch. 80, $\S 1-2,[1918]$ Gen. Laws of Texas 170. 
history of de jure segregation toward Hispano-Americans based on the acts and policies of school officials.

In United States v. Texas Education Agency, ${ }^{168}$ a case arising in Austin, the Fifth Circuit found intentional segregative action on the part of the school district-particularly in the choice of school site locations, construction of schools, drawing of attendance zones, student assignment and transfer policies, and faculty and staff assignments. ${ }^{169}$ Thus de jure segregation against Hispanos was found despite the absence of a previous statutory requirement. The court stated that discrimination in this case was "no different from any other school desegregation case." 170 Similarly, in Cisneros v. Corpus Christi Independent School District, ${ }^{171}$ the court found de jure segregation, noting that the ${ }^{172}$

de jure nature of the existing pattern of segregation within the Corpus Christi Independent School District has as its basis state action of a non-statutory variety-that is, the school board's active pursuit of policies that not only do nothing to counteract the effect of existing patterns of residential segregation in view of viable alternatives of significant integrative value, but, in fact, increase and exacerbate the district's racial and ethnic imbalance. There has been a history of official school board acts which have had such a segregative effect.

Thus, once the necessary intentional segregative actions are foundcoupled with the high concentration of Hispanos in certain schools and the low percentage of Hispano teachers in relation to the Hispano percentage of the total student population-a prima facie case of unlawful segregation is established. There are cases, however, in which the Denver case principles are applied to reach a finding of no de jure segregation. In Zamora $v$. New Braunfels Independent School District, ${ }^{173}$ plaintiffs failed to establish that the actions of school authorities were taken with segregative intent. The court held that the existing segregation was "de facto and strictly the result of shifting residential patterns within the community." 174 Since there was no constitutional violation, there could be no relief.

In a school desegregation case in California, the district court initially treated the case as one of de facto segregation but held that the mere existence of the segregated elementary schools was a denial of equal protection of the laws and that the school board had an affirmative duty to eliminate the racial imbalance. ${ }^{175}$ The Ninth Circuit remanded the case for a finding of whether or not the school board had intentionally pursued a policy of racial segregation. ${ }^{176}$ The circuit court stated that it is not until a finding of intentional segregation

168. 467 F.2d 848 (5th Cir. 1972).

169. Id. at 864-66.

170. 467 F.2d at 873 .

171. 324 F. Supp, 599 (S.D. Tex. 1970).

172. $I d$. at 620 n. 58.

173. 362 F. Supp. 552 (W.D. Tex. 1973).

174. Id. at 559 .

175. Soria v. Oxnard School Dist. Bd. of Trustees, 328 F. Supp. 155, 159 (C.D. Cal. 1971 ).

176. 488 F.2d 579 (9th Cir. 1973). On remand the district court did find intentional segregative actions on the part of the board, 386 F. Supp. 539 (C.D. Cal. 1974). 
has been made that the affirmative duty of the school board to convert the system to a "unitary" one attaches. ${ }^{177}$

There are cases, however, which seem to have adopted a more lenient standard for establishing a prima facie case than that set forth in the Denver case. In Serna v. Portales Municipal Schools ${ }^{178}$ the district court did not require a showing of past, intentional segregative acts. Reliance instead was placed on the long-standing educational policy of the school district which failed to take into consideration the specific needs of Spanish-speaking students. The only proof required was the establishment of the existence of a substantial number of Hispano children and the nonexistence of a special curriculum tailored to their needs. The court focused in particular on the district's failure to provide a bilingual educational program. The Tenth Circuit affirmed but on statutory rather than on constitutional grounds. ${ }^{179}$

To sum up, the few cases dealing with the isolation of Hispano-Americans indicate that proof of a violation of the equal protection clause based on the existence of predominantly minority schools requires a showing of de jure segregation attributable to the action of school officials. The same analysis is used for cases of Hispano segregation as is used in cases involving discrimination against blacks except that, since Hispanos do not always have the "benefit" of a previous state statute requiring segregation, intent or purpose to segregate must be read into those actions of school authorities which result in segregated schools. However, the Serna case may represent a new approach under which Hispanos will be exempted from having to show past and present intentional segregative actions.

\section{Remedial Limits}

Except in the case of "pure" de facto segregation, the rules for establishing a constitutional violation are relatively clear and non-controversial. The real concern today is not whether, in a de jure segregated school district, the constitutional rights of black children are being violated. Rather, the primary controversy-once the constitutional violation has been found-is over remedies, i.e., to what extent desegregation will be required, and by which means such desegregation is to be achieved.

\section{A. Background}

Local school authorities have the primary responsibility for insuring desegregation. In judging whether local authorities have met that responsibility, and in fashioning remedial decrees where they have not, the federal courts are to

177. 488 F.2d at 585.

178. 351 F. Supp. 1279 (D.N.M. 1972), aff'd on other grounds, 489 F.2d 1147 (10th Cir. 1974).

179. 499 F.2d 1147 (10th Cir. 1974). 
be guided by traditional principles of equity. ${ }^{180}$ The objective to be achieved is "the elimination of . . . deliberately maintained dual school systems with certain schools for Negro pupils and others for white pupils." ${ }^{81}$ The local school authorities and the courts must strive to "eliminate . . . all vestiges of stateimposed segregation," 182 and "achieve the greatest possible degree of actual desegregation, taking into account the practicalities of the situation." ${ }^{183}$

Once a right and a violation have been shown, the scope of a district court's equitable powers to remedy past wrongs is broad, for breadth and flexibility are inherent in equitable remedies. ${ }^{184}$

And finally, "[t]he remedy . . . may be administratively awkward, inconvenient, and even bizarre in some situations and may impose burdens on some . . ."185

\section{B. Intra-District Remedies}

The most detailed discussion of the various equitable remedies available to a federal district court is found in Swann: There the Court endorsed a range of possible steps that a lower court could require a school district to take once an equal protection violation had been established; the Court also clearly indicated that the use of these remedial steps is limited, depending upon the circumstances.

The major permissible remedies discussed in Swann can be clustered around four somewhat overlapping subject areas: (1) racial balance; ${ }^{186}$ (2) one-race schools; ${ }^{187}$ (3) altering of attendance zones and pairing, clustering, or grouping of schools; ${ }^{188}$ and (4) transportation of students from one part of the district to schools in another part-i.e., busing. ${ }^{189}$ Minority to majority transfer plans may also be used if they are effective in achieving a non-racial, unitary school system. ${ }^{190}$

180. Brown v. Board of Educ. (Brown II), 349 U.S. 294, 300 (1955). "Traditionally, equity has been characterized by a practical flexibility in shaping its remedies [footnote omitted] and by a facility for adjusting and reconciling public and private needs." Id. But see Milliken v. Bradley, 418 U.S. 717 (1974), holding in effect that a federal court's remedial powers stop at the school district line or "[T]he scope of the remedy is determined by the nature and the extent of the constitutional violation." Id at 744 .

181. Id at 737.

182. Swann v. Charlotte-Mecklenburg Bd. of Educ., 402 U.S. at 15.

183. Davis v. Board of School Comm'rs, 402 U.S. 33, 37 (1971). Desegregation must extend not only to student assignment policies, but also to the hiring, firing, and treatment of faculty and staff; the quality of the physical plant; the use of transportation to and from school; and the organization of extra-curricular activities. Swann v. Charlotte-Mecklenburg Bd. of Educ., 402 U.S. at 18-19.

184. 402 U.S. at 15 .

185. 402 U.S. at 28 .

186. 402 U.S. at $22-25$.

187. 402 U.S. at $25-27$.

188. 402 U.S. at $27-29$.

189. 402 U.S. at $29-30$.

190. 402 U.S. at 26-27. 


\section{Racial Balance}

Swann raised the question of the degree to which racial balance can be required in formulating a remedy; that is, to what extent must the proportions of each race in a school correspond to the proportions of each race in the system as a whole? The Court held that the use of mathematical ratios as part of a plan to facilitate the disestablishment of a dual school system is permissible, but in and of itself, racial balance is not required by the Constitution: ${ }^{191}$

The constitutional command to desegregate schools does not mean that every school in every community must always reflect the racial composition of the school system as a whole ... [although] the use ... of mathematical ratios [and] ... [a]wareness of the racial composition of the whole school system is likely to be a useful starting point in shaping a remedy . . .

\section{One-race Schools}

In placing limitations on the use of ratios to achieve racial balance, the Court also indicated that the existence of one-race schools is not constitutionally invalid per se. However, the burden in a previously de jure segregated school system is on the school officials to justify that assignments to these schools are non-discriminatory. ${ }^{192}$

[1]t should be clear that the existence of some small number of one-race, or virtually one-race, schools within a district is not in and of itself the mark of a system that still practices segregation by law. . . Where the school authority's proposed plan ... contemplates the continued existence of some schools that are all or predominantly of one race, they have the burden of showing that such school assignments are genuinely nondiscriminatory.

If the one-race school is a relict of a previous policy of racial assignment and the school board has subsequently adopted a neighborhood-schools policy, presumably-according to language in Swann regarding the elimination of all "vestiges of state-imposed segregation"-the Court would find assignment to that school discriminatory.

\section{Altering Attendance Zones}

With regard to the pairing of schools and altering of attendance zones, Swann indicated that a racially-neutral student assignment plan-such as a neighborhood school plan or a freedom-of-choice plan-is not acceptable if it is ineffective in reducing racial imbalance in a previously de jure segregated school system. ${ }^{193}$ When would a neighborhood school assignment policy be

191. 402 U.S. at 24, 25; Milliken v. Bradley, 418 U.S. at $740-41$ \& n. 19. The Court said in Swann:

If we were to read the holding of the District Court to require, as a matter of substantive constitutional right, any particular degree of racial balance or mixing, that approach would be disapproved and we would be obliged to reverse.

402 U.S. at 24.

192. 402 U.S. at 26 .

193. 402 U.S. at 28. Accord, Wright v. Council of the City of Emporia, 407 U.S. 451,460 (1972); Green v. County School Bd., 391 U.S. 430, 440 (1968). 
permissible? Some members of the Supreme Court seem to place a high priority on neighborhood schools. Chief Justice Burger indicated in Swann that such a policy might be preferable, under certain circumstances, to any other policy of assignment: ${ }^{194}$

All things being equal, with no history of discrimination, it might well be desirable to assign pupils to schools nearest their homes. But all things are not equal in a system that has been deliberately constructed and maintained to enforce racial segregation.

Justice Powell, concurring in part and dissenting in part in Keyes, strongly advocated neighborhood schools and sought to curb the use of busing solely for purposes of maximizing racial balance if it would impact too heavily on neighborhood schooling. ${ }^{195}$

In Ellis v. Board of Public Instruction, ${ }^{196}$ the Fifth Circuit delineated the elements of a legal neighborhood school plan: each student must be assigned to attend the school nearest his or her home, limited only by the capacity of the school, and then to the next nearest school, without variance or exception and without regard to whether the school was formerly black or white. ${ }^{197}$ The plan, however, must result in desegregation as measured by the six indicia first outlined in Green: desegregation of student bodies, faculty, staff, transportation, extracurricular activities, and facilities. ${ }^{198}$ On the basis of this holding, Chief District Judge Frank Johnson later approved the Montgomery school board's proposal for a neighborhood elementary school plan which left onethird of the thirty-three elementary schools with over 80 per cent black enrollment ${ }^{199}$ - meaning that 55 per cent of black elementary school students were still enrolled in predominantly black schools. Judge Johnson based his decision on three grounds: (1) "every black student at some point in his school career will be exposed to complete desegregation" ${ }^{200}$ since in grades 7-12 the system would be completely desegregated; (2) "the system as a whole will be desegregated";201 and (3) there is educational "value in having elementary children attend schools near their homes," 202 although he cited no empirical or other evidence to support this statement. He concluded that "[i]f a neighborhood elementary school system can be effected without a sacrifice of constitutional standards, then such a plan should be adopted." 203

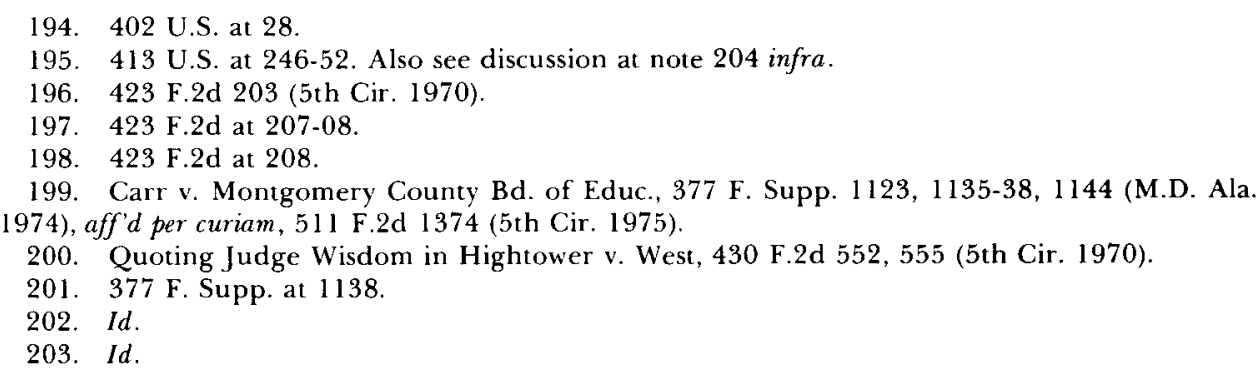




\section{Busing}

The most controversial aspect of school desegregation is busing-the transportation of students from one part of the district to a school in another part of the district to achieve desegregation. The Supreme Court in Swann approved busing as a tool to be used in disestablishing a dual school system, although it indicated that there are limits to the use of the remedy. While suggesting such limits, however, the Court declined to provide any specific guidelines for future cases, saying only that busing could be used where "feasible," but its use was to be limited by considerations of times and distances which would "either risk the health of the children or significantly impinge on the educational process." 204

Without explicit guidance from the Supreme Court, lower courts in the post-Swann period have taken different approaches with regard to the extent of busing that will be permitted. A federal district court in Memphis-where total desegregation could have been accomplished by a plan involving bus rides of up to 60 minutes-accepted a plan which left some 25,000 black students in 25 all-black schools, but which reduced the average bus ride to 38 minutes with no ride more than 45 minutes. ${ }^{205}$ All of this was done without much apparent help from the social or medical sciences in determining whether 60 minutes risks children's health or "significantly impinge[s] on the educational process." 206

204. 402 U.S. at 29-31. In the Denver case Justice Powell took a strong position against the use of large-scale busing as a constitutional remedy, particularly with regard to elementary school children:

[T] he legitimate community interests in neighborhood school systems [should] be accorded far greater respect. In the balancing of interests so appropriate to a fair and just equitable decree, transportation orders should be applied with special caution to any proposal as disruptive of family life and interests-and ultimately of education itself-as extensive transportation of elementary-age children solely for desegregation purposes. As a minimum, this Court should not require school boards to engage in the unnecessary transportation away from their neighborhoods of elementary-age children. [Footnote omitted.] It is at this age level that neighborhood education performs its most vital role. It is with respect to children of tender years that the greatest concern exists for their physical and psychological health. It is also here, at the elementary school, that the rights of parents and children are most sharply implicated.

205. Plans 1 and III, as presented to the district court, would have placed 97 per cent of all students in desegregated units, 48,000 children would have been bused, and a majority of those ( 75 per cent or 80 per cent) would have a bus ride of 31 to 45 minutes each way. Of those bused, 9,700 students would have a 46 to 60 minute ride each way, and most of these would be elementary school students. Plan II, which the court adopted, leaves 25 all-black or predominantly black units (19 elementary schools, 4 junior high schools, and 2 high schools), 83 per cent of the students will attend school in desegregated units, 38,000 children will be bused, and 44 per cent of these will have a 31 to 45 minutes bus ride each way, with no ride being over 45 minutes. Northcross v. Board of Educ., 489 F.2d 15, 16-17 (1973).

206. See Northcross v. Board of Educ., 341 F. Supp. 583 (W.D. Tenn. 1972), aff'd, 489 F.2d 15 (5th Cir.), cert. denied, 416 U.S. 962 (1973). On first appeal, the circuit court upheld the district court's finding that more busing was impractical during that school year, 466 F.2d 890,895 (6th Cir. 1972). However, the court recognized that further desegregation was necessary and directed the district court to prepare a timetable for the system's future desegregation. Id. In rejecting the 
In Thompson v. School Board, ${ }^{207}$ the Fourth Circuit Court of Appeals upheld an order by the district court that a desegregation plan which would have involved bus rides of up to two and one-half hours of travel time a day for first and second graders was not "feasible." 208 The defense introduced the expert testimony of a pediatrician concerning the possible harmful effects of busing on young children which the plaintiffs left uncontroverted. ${ }^{209}$

The use of intradistrict busing has also been limited by Congress under the 1974 Education Amendments. ${ }^{210}$ This education package prohibits a federal court from ordering busing to remedy de jure segregation unless the court first makes a finding that all alternative remedies are inadequate. ${ }^{211}$ And when

defendant's social science evidence as to the ill effects of busing, the circuit court expressly questioned the applicability of the Armor busing study to that case, finding its conclusions to be "inapplicable to the Southern school pattern." 466 F.2d at 894 \& n. 4

On remand, the district court, in an unpublished memorandum, approved a final desegregation plan involving the busing of 38,000 pupils, with no rides over 45 minutes long, even though this plan left untouched by the order two all-black high schools, four all-black junior high schools and 19 all or predominantly black elementary schools. 489 F.2d at 16-17. The Sixth Circuit affirmed the district court's consideration of the "practicalities" involved in busing, and quoted with approval from the memorandum decision:

The lesser degree of desegregation in [the plan adopted] is based primarily upon four

factors pertaining to effectiveness, feasibility and pedagogical soundness. Those factors are time and distance traveled on buses, cost of transportation, preservation of desegregation already accomplished, and adaptability.

489 F.2d at 17. Although it had previously rejected the defendant's social science evidence that busing itself was undesirable, the Sixth Circuit apparently approved of the use of such evidence in determining how much busing to use, noting that "[t]he one psychological expert was of the opinion that a shortening of the times and distances of transportation would inure to the benefit of many school children, especially the younger ones." Id.

207. 498 F.2d 195 (4th Cir. 1974).

208. Id at 196-97. The district court's finding does not seem unreasonable and the ruling may have been prompted by tactical errors on the plaintiffs' part. Their expert witness was unfamiliar with the local situation in Newport News, and testified that the time and distance to be traveled had not entered into his considerations when preparing the plaintiff's desegregation plan. $363 \mathrm{~F}$. Supp 458, 461-62 (E.D. Va. 1973).

209. The pediatrician had testified that young children would be "physically and psychologically affected by compulsory bus transportation for long periods of time . . ." $363 \mathrm{~F}$. Supp. at 460 . This decision was upheld on appeal, 498 F.2d at 197. Judge Winter, in his dissenting opinion, found reliance on the pediatrician's testimony inappropriate:

I record my suspicion of the basis on which the district court approved retention of a dual system for grades 1 and 2 . It relied heavily on the testimony of . . a pediatrician, to the effect that the health of students in kindergarten and the first and second grades would be adversely affected if they were not permitted to attend neighborhood schools. But as 1 read the testimony ... it was . . . that the effect of transportation on the physical and mental health of a child depends upon whether he is transported to a school "of his choice or his parents' choice." If the child is unhappy, i.e., not transported to a school of his choice or his parents" choice, "then it follows from there, as the night does the day, that you're just going to have a poor situation." Acceptance of [the pediatrician's] thesis, it seems to me, would be to require application of the equal protection clause to depend upon a plebiscite by parents. .. .

498 F.2d at 198-99.

210. Equal Educational Opportunity Act of 1974, 20 U.S.C.A. $\$ 11701-58$ (Cum. Supp. 1975).

211. Notwithstanding any other provision of law,... no court of the United States shall order the implementation of any plan to remedy a finding of de jure segregation which involves the transportation of students, unless the court first finds that all alternative 
busing is used, the amendments provide that no student should be bused beyond the school next closest to his home, ${ }^{212}$ unless the courts determine that more extensive busing is necessary to ensure the protection of constitutionally guaranteed civil rights. ${ }^{213}$ This important proviso seems to leave intact the

remedies are inadequate.

20 U.S.C.A. $\S 1755$ (Cum. Supp. 1975).

The alternative remedies, which appear to require their application seriatim, are as follows: In formulating a remedy for a denial of equal educational opportunity or a denial of the equal protection of the laws, which may involve directly or indirectly the transportation of students, a court, department, or agency of the United States shall consider and make specific findings on the efficacy in correcting such denial of the following remedies and shall require implementation of the first of the remedies set out below, or of the first combination thereof which would remedy such denial:

(a) assigning students to the schools closest to their places of residence which provide the appropriate grade level and type of education for such students, raking into account school capacities and natural physical barriers;

(b) assigning students to the schools closest to their places of residence which provide the appropriate grade level and type of education for such students, taking into account only school capacities;

(c) permitting students to transfer from a school in which a majority of the students are of their race, color, or national origin to a school in which a minority of the students are of their race, color, or national origin;

(d) the creation or revision of attendance zones or grade structures without requiring transportation beyond that described in section 1714 of this title;

(e) the construction of new schools or the closing of inferior schools;

(f) the construction or establishment of magnet schools; or

(g) the development and implementation of any other plan which is educationally sound and administratively feasible, subject to the provisions of section 1714 and 1715 of this title.

20 U.S.C.A. $\$ 1713$ (Cum. Supp. 1975) (emphasis added).

212. (a) No court, department, or agency of the United States shall, pursuant to section 1713 of this title, order the implementation of a plan that would require the transportation of any student to a school other than the school closest or next closest to his place of residence which provides the appropriate grade level and type of education for such student.

(b) No court, department or agency of the United States shall require directly or indirectly the transportation of any student if such transportation poses a risk to the health of such student or constitutes a significant impingement on the educational progress with respect to such student.

(c) When a court of competent jurisdiction determines that a school system is desegregated, or that it meets the constitutional requirements, or that it is a unitary system, or that it has no vestiges of a dual system, and thereafter residential shifts in population occur which result in school population changes in any school within such a desegregated school system, no educational agency because of such shifts shall be required by any court, department, or agency of the Cnited States to formulate. or implement any new desegregation plan, or modify or implement any modification of the court approved desegregation plan, which would require transportation of students to compensate wholly or in part for such shifts in school population so occurring.

20 U.S.C.A. $\$ 1714$ (Cum. Supp. 1975)

213. Any court order requiring. directly or indirectly, the transportation of students for the purpose of remedying a denial of the equal protection of the laws may, to the extent of such transportation. be terminated if the court finds the defendant educational agency has satisfied the requirements of the fifth or fourteenth amendments to the Constitution. whichever is applicable, and will continue to be in compliance with the requirements thereof. . . No additional order requiring such educational agency to transport students for such purpose shall be entered unless such agency is found not to have satisfied the 
remedial powers of the federal courts already judicially defined in cases such as Green and Swann. The law also allows parents and educational agencies to seek to reopen a busing order but-using language from the Swann decision-only if the time or distance traveled is so great as to endanger the health of the student or impinge on the educational process. ${ }^{214}$

The courts may well take a restrictive view of congressional efforts to impose limits on school desegregation. In Darville v. Dade County School Board, ${ }^{215}$ the plaintiffs challenged the authority of the school district to continue to use pupil assignment and transportation plans "to ensure the continued existence of the unitary system."216 Plaintiffs alleged that the following provisions of the Education Amendments of 1972 were violated by the actions of the school board: ${ }^{217}$

No provision of this Act shall be construed to require the assignment or transportation of students or teachers in order to overcome racial imbalance.

No court or official of the United States shall be empowered to issue any order seeking to achieve a racial balance in any school by requiring the transportation of pupils or students from one school to another or one school district to another in order to achieve such racial balance, or otherwise enlarge the existing power of the court to ensure compliance with constitutional standards shall apply to all public school pupils and to every public school system, public school and public school board....218

The court noted that school boards are vested with broad discretion in pupil assignments and that there is nothing in the above-quoted amendments which would restrict the actions of public school boards as nothing in either of the amendments applies to voluntary action by local school boards. Moreover, $\S$ 1656 can only be read as applying to federal officials and agencies. ${ }^{219}$

\section{Summary of Permissible Intradistrict Remedial Tools}

To summarize, the constitutional objective of the courts is "to eliminate from the public schools all vestiges of state-imposed segregation." "220 To achieve

requirements of the fifth or fourteenth amendments to the Constitution, whichever is applicable.

20 U.S.C.A. \& 1718 (Cum. Supp. 1975).

214. A parent ... of a child . . transported to a public school in accordance with a court order, or an educational agency subject to a court order or a desegregation plan under Title VI of the Civi] Rights Act of 1964 in effect on [the date of the enactment of this section] and intended to end segregation of students on the basis of race, color, or national origin, may seek to reopen or intervene in the further implementation of such court order ... if the time or distance of travel is so great as to risk the health of the student or significantly impinge on his or her educational process.

20 U.S.C. $\$ 1717$ (Cum. Supp. 1975).

215. 497 F.2d 1002 (51h Cir. 1974).

$216 . \quad I d$. at 1003.

217.20 U.S.C.A. $\$ 1651-56(1974)$.

218.20 U.S.C.A. $\$ 1956$ (1974).

219. 497 F.2d at 1004-05.

220. Swann v. Charlotte-Mecklenberg Bd. of Educ., 402 U.S. at 15 
this objective, Swann says that an "[a]wareness of the racial composition of the whole school system is likely to be a useful starting point in shaping a remedy to correct past constitutional violations"; ${ }^{21}$ thus, "the very limited use . . of mathematical ratios [is] within the equitable remedial discretion of the District Court." 222 Nevertheless, "[t]he constitutional command to desegregate schools does not mean that every school in every community must always reflect the racial.composition of the school system as a whole."223 While there is a presumption against "one-race" schools, it can be overcome if school authorities can show that the racial composition of "some small number of one-race, or virtually one-race, schools" is "not the result of present or past discriminatory action" on the part of school officials. ${ }^{24}$ The pairing or clustering of schools, the altering of attendance zones, and majority-minority transfer plans also are permissible remedial tools to achieve the objective. Busing is a permissible tool as well, but it is limited by time and distance according to the age of the students involved.

\section{Black Backlash and White Flight}

\section{Black Opposition}

There is another important issue in the remedial area: what recourse is there when a specific remedy disproportionately burdens minorities? This issue has arisen in two overlapping contexts: where there is "one-way" busing (only minority students are bused out of their neighborhoods to attend schools in white neighborhoods) and where a formerly all-black school is closed but white schools are not. The first issue was raised in Norwalk CORE v. Norwalk Board of Education, which held that one-way busing was within the discretion of the school board absent a finding of either de jure segregation or a lack of good faith on the part of the board. ${ }^{225}$

In some of the more recent decisions, courts have been readier to acknowledge the problem of imposing a disproportionate burden on minorities in any desegregation plan, but in most of these cases-after the court has made the token statement that the burdens of desegregation can not be imposed on only one group-the result is the same. In Hart $v$. Community School Board, ${ }^{226}$ for example, the district judge's amended order called for the school in question to be turned into a "magnet" school in order to attract more whites. ${ }^{227}$ The plaintiffs objected, in part because substantially more minority students (1050) than

221. Id. at 25 .

222. Id.

223. 402 U.S. at 24 .

224. 402 U.S. at 26.

225. 298 F. Supp. 213, 224-26 (D. Conn. 1969), affd, 423 F.2d 122 (2d Cir. 1970). Accord, Moss

v. Stamford Bd. of Educ., 356 F. Supp. 675 (D. Conn. 1973).

226. 512 F.2d 37 (2d Cir. 1975).

227. 383 F. Supp. 769. $770-74$ (E.D.N.Y. 1974). 
white students (650) were to be bused. ${ }^{228}$ The Second Circuit held, however, that ${ }^{229}$

the "burden" of busing cast upon minority students is only a "somewhat heavier burden" ... . A "somewhat heavier burden" has to fall somewhere, either on white or minority students as a class.

In Higgins v. Board of Education, ${ }^{230}$ the plaintiffs alleged that the Grand Rapids school board's affirmative desegregation plan was illegal in providing for "one-way" busing from the central city (where blacks were concentrated) to the peripheral areas-because the school board thought that any other plan would result in white flight to the suburbs. ${ }^{231}$ The Sixth Circuit, while recognizing that the "burdens and inconveniences of integration should not be placed discriminatorily" stated that ${ }^{232}$

the authority of school of ficials to formulate plans for achieving an improved racial balance should not be as restrictive in the case of a school system which has not been found to have engaged in purposeful segregation as for a system which has practiced de jure segregation.

With regard to the "white flight" justification of the school board, the circuit court emphasized that there was a ${ }^{233}$

valid distinction between using the defense of white flight as a smokescreen to avoid integration and realistically considering and dealing with the practical problems involved in making voluntary efforts to achieve integration.

Despite the often expressed concern over busing particularly young children, courts have not seen fit to regard plans which call for busing only black children in the earliest years as being a disproportionate burden on one race. In Nashville, the school board devised a plan which called for busing black students in grades one to four to outlying schools while white students were not bused unless they were in grades five and six. ${ }^{234}$ The circuit court approved, stating that "We do not believe . . that we can appropriately hold the District Judge abused his discretion ...."235 Similarly, the Fourth Circuit considered acceptable a plan whereby black students in grades three through five were to be bused out of their neighborhoods to attend schools in white neighborhoods, while white students in grades six and seven were bused to formerly black schools. ${ }^{236}$ The plaintifis had argued that "such assignments placed an undue and discriminatory burden on black students" inasmuch as ${ }^{237}$

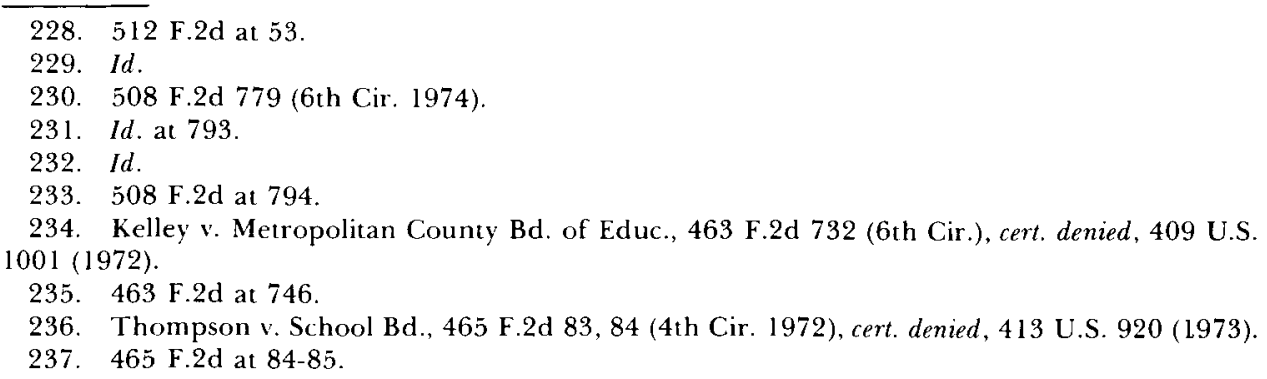


the white school child would attend for his first five school years a school formerly identified as a white school and located in a white neighborhood, whereas the black child would be in a school located in a black neighborhood only in his first two grades and in his 6 th and 7 th grades.

The courts have also held that it is permissible to close formerly all-black schools if the closing is not based on "racial considerations." 238 But what set of facts leads to the conclusion that the closing was due to non-racial reasons? For example, the closing of five formerly black schools in Jacksonville, Florida, was approved on these grounds: all were deteriorated; one was surrounded by a slaughter house, a polluted creek, and a city incinerator; and in three other schools the "[i]ncidences of vandalism and intrusion [were so frequent and serious] that teachers and children [were] locked in their rooms for safety." ${ }^{239}$

It is clear, however, that there is a heavy burden on the school board to show that the closing of formerly black schools is not for racial reasons. With regard to the desegregation of Austin schools, the district court ordered two all-black schools to be closed. The Fifth Circuit found "the closing of two all-black schools and the transfer of the students from those schools to other schools in the system . . . unacceptable . . where there was no showing that these schools were closed for non-racial reasons" and where a similarly situated white school was not closed. ${ }^{240}$ The fact that the possibility of white flight "was the real reason for the closing of the two schools" was not a legitimate justification. ${ }^{241}$

In Arvizu v. Waco Independent School District, the Fifth Circuit went even further. ${ }^{242}$ The school board had given reasons for the closing of minority schools-the facilities were outmoded, they operated at under capacity or the capacity was so limited that the costs of operation were prohibitive, and the physical plant was too small. ${ }^{243}$ The court held, however, that the board must do more than give "facially legitimate" justifications. It "must adduce evidence sufficient to support" the conclusion that "their actions were not in fact motivated by racial reasons" 244 sufficient to support the conclusion. The district court, on remand, was to re-examine the justifications for closing the minority schools "in light of the characteristics of the schools permitted to remain in operation ... and ... the timing of the proposed school closings . . .."24s

238. Ellis v. Board of Pub. Instruction, 465 F.2d 878, 880 (5th Cir. 1972), cert. denied, 410 L.S. 966 (1973); Lee v. Macon County Bd. of Educ.. 448 F.2d 746, 753-54 (5th Cir. 1971); Mims v. Duval County School Bd., 447 F.2d 1330, 133 I-32 (5th Cir. 1971); Carr v. Montgomery County Bd. of Educ.. 429 F.2d 382.385 (5th Cir. 1970).

239. Mims v. Duval County School Bd., 447 F.2d at 1332-33. Several of these schools have now reopened. Letter from Norman Chachkin. Staff Attorney. NAAC:P Legal Defense and Educational Fund. Inc., to the senior author, November 1974, on file at Lau and Contemporary Problems office.

240. United States v. Texas Educ. Agency, 467 F.2d 848, 871-72 (5th Cir. 1972).

24l. 467 F.2d at 872 .

242. 495 F.2d 499 (5th Cir. 1974).

243. Id. at 505 .

244. Id.

245. 495 F.2d at 506. 
Of what relevance is minority opposition-to the extent that it exists-to desegregation? ${ }^{246}$ There have been only a few cases so far even to acknowledge the existence of this possibility. In Hart v. Community School Board, the district court noted that some commentators have "urged that self-imposed segregation in the public schools is desirable and therefore constitutional," 247 citing, among others, Mosteller and Moynihan's review and reanalysis of the Coleman Report findings. ${ }^{248}$ Responding to this argument, the District Judge noted that ${ }^{249}$

[t] his position would have to be rejected even were there basis in fact for the proposition that segregated schools improved the education of black students-a proposition belied by data available to date.

Judge Weick of the Sixth Circuit, dissenting in Mapp v. Board of Education, ${ }^{250}$ took a different position. He opposed the court-ordered integration through busing as resulting "in the violation of the constitutional rights of innocent black children and white children," ${ }^{51}$ primarily the right of freedom of association. In support of this, he stated that "[m]any black people [oppose] forced bussing of their children," citing statements made at the National Black Political Convention held in Gary, Indiana in $1972^{252}$ to the effect that mandatory busing is racist and preserves a black minority structure.

As part of its Experimental Schools program, funded by HEW, the Berkeley school system recently experimented with optional schools offering alternative educational environments for black and Chicano students-schools whose enrollments, although not expressly limited to these minority students, were racially exclusive by choice. The debate over the constitutionality of such schools fostering voluntary segregation seems to pit the Brown decision and the fourteenth amendment against the first amendment's freedom of association. Is there a point at which Brown's demand for integration becomes satisfied so that resegregation by choice becomes constitutionally permissible $?^{253}$ Inasmuch

246. See, e.g., Bell, supra note 126; Epps, Assimilation, Pluralism, and Separation, in AmEricax Education in Rethinking Educational Equality 49 (A. Kopan and H. Walberg eds. 1974); Sizemore, Is There a Case for Separate Schools?, supra note 129.

247. 383 F. Supp. 699, 742 (E.D.N.Y. 1974).

248. On Equality of Educational Opportunity (F. Mosteller \& D. Moynihan eds. 1972). Judge Weinstein also cited Robinson, Preparation for Life: The Black Classroom, in B LACK MANifesto for Education 3 (J. Haskins ed. 1973) and R. Crary \& L. Petrone, Foundation of Modern EDUCATION (1971).

249. $383 \mathrm{~F}$. Supp. at 742 . The court later notes that "the evidence supports neither the argument that desegregated public school education is not helpful to the minorities, nor that it adversely affects whites," 383 F. Supp. at 744, further noting, however, that "much of the current research replies to precise policy based questions with the ambiguity of a Delphic oracle . . ." $I d$.

250. 477 F.2d 851 (6th Cir.). cert. denied. 414 U.S. 1022 (1973).

251. 477 F.2d at 856 .

252. 477 F.2d at 856 n. 4 .

253. See Comment, Alternative Schools for Minority Students: The Constitution, the Civil Rights Act and the Berkeley Experiment. 61 Calif. L. Rev. 858 (1973). Cf. Comment. Separate Black Facilities on Campus: A Ligal and Practical Evaluation. 7 Colum. J.L. \& Social. Prob. 107 (1971).

It should be noted that Berkeley had become a fully unitary, integrated system and that the two 
as the Court in Green said that freedom-of-choice plans are not unconstitutional per se, ${ }^{254}$ the Berkeley situation-where the system is unitary and where any minority student may choose to remain in an integrated school in the system-may be the appropriate one for a freedom-of-choice pupil assignment plan.

Somewhat related to these examples is the so-called "Atlanta Compromise." The Atlanta school system had an enrollment that was 70 per cent white and 30 per cent black at the time the first desegregation suit was filed in 1958.255 By 1973, the enrollment was 79 per cent black and 21 per cent white. ${ }^{256}$ Some (but not all) of the plaintiffs who filed the original desegregation suit, seeing that the school system was rapidly resegregating and believing that further efforts to integrate the few remaining white students would be futile, opted instead for an agreement with the school board for the allocation of more administrative positions to blacks--including a black superintendent. The district court approved the plan in Calhoun v. Cook ${ }^{257}$ with some modifications, noting that it satisfied "the overwhelming majority of the plaintiff class" and the plan was "fair, adequate, and reasonable." ${ }^{58} 8$ The plan left 59,000 black students-about 60 per cent of the school system-in schools 90 per cent black. ${ }^{259}$ Enough students were transferred to ensure that there were no schools 90 per cent white. ${ }^{260}$ The Fifth Circuit remanded the cases, however, for further findings, saying that the adoption of the compromise was improper since the facts as to the compromise agreement were in dispute. ${ }^{261}$

In an earlier phase of this case, the district court had noted that in view of demographic patterns within Atlanta, the only device which could effect racial balance in each school ( 70 per cent black to 30 per cent white pupil enrollment) was mass busing. However, the court found that the time and distances involved would make it impractical. The court had considered the possibility of

schools-Black House and Casa de la Raza-served a very small proportion of the total number of minority students enrolled in the district. Black House served a student body of 75 high school students, while over 1400 blacks attended integrated high schools in Berkeley. Casa de la Raza served 125 Chicano students of a total of 427.

Under pressure from HEW, the Berkeley public school system withdrew its support for these two schools. HEW's Office of Civil Rights eventually accepted a plan whereby students would be permitted to spend 20 per cent of their school time attending Black House or Casa de la Raza. Black House, however, closed down and has never been revived. Casa de la Raza did submit a skeletal plan to the Berkeley school district last fall, but was told there were no more funds from HEW for the Experimental Schools Program. Communication from David L. Kirp, Associate Professor, Graduate School of Public Policy and Lecturer, School of Law, University of California at Berkeley, and consultant to the Berkeley School System, June 19, 1975

254. See note 51 supra and accompanying text.

255. Calhoun v. Cook, 332 F. Supp. 804, 805 (N.D. Ga. 1971). See also Bell, supra note 126.

256. Calhoun v. Cook, 362 F. Supp. 1249, 1251 (N.D. Ga. 1973).

257. 362 F. Supp. at 1249.

258. 362 F. Supp. at 1252.

259. Id.

260. Atlanta Constitution, April 5, 1973, \& A, at 1, col. 1.

261. 487 F.2d 680, 682 (5th Cir. 1973). Following remand, the district court issued an unreported opinion which is now on appeal. The case is now in its seventeenth year. 
requiring the transportation of black students from the center of the city to the white periphery, but noted, without further explanation, that such a move would be "opposed by a large group of blacks except on a voluntary basis ...."262 Therefore, the remedy of "mass" busing was rejected.

\section{White Flight}

One potential limit to consider in shaping a desegregation remedy is the phenomenon of "white flight." Should a desegregation plan take into account the "tipping point" beyond which "white flight" accelerates precipitously? If a court order seemed likely to induce "white flight" from the community or from the public school system to such a degree that desegregation would become impossible, is it constitutionally permissible to substitute a lesser remedy?

The question of the effect of a court order on "white flight," or vice versa, has arisen several times in the Fourth Circuit. In Beckett v. School Board, ${ }^{263}$ the district court approved an interim "desegregation" plan consisting only of a limited freedom-of-choice option in the elementary schools. The court took the position that ${ }^{264}$

[a]ny attempt to radically desegregate schools of Norfolk lying readily adjacent to [predominantly white] Virginia Beach will lead to white-flight, a fact that is certainly not desirable from the stand-point of sound educational principles. . . .

In this respect the court relied on a number of social science research studies, ${ }^{265}$ quoting at length from that of Professor Pettigrew regarding the advantages of retaining a white majority in schools: ${ }^{266}$

Negroes in predominantly white classrooms score higher on the average, but those Negroes in classrooms with less than one-half whites do no better than those in all Negro classrooms.

The Fourth Circuit subsequently reversed the decision without specifically addressing itself to the "white flight" issue ${ }^{267}$ In Brunson v. Board of Trustees, ${ }^{268}$ however, the Fourth Circuit did confront the issue directly. In separate opinions by Judges Craven and Sobeloff, the relevance of such testimony as that of

262. 332 F. Supp. at 807-08. The court does not indicate how it obtained the opinion of "a large group of blacks."

263. 302 F. Supp. 18 (E.D. Va. 1969), rev'd sub nom. Brewer v. School Bd., 434 F.2d 408 (4th Cir.), cert. denied 399 U.S. 929 (1970).

264. 302 F. Supp. at 30 (emphasis added).

265. 302 F. Supp. at $29-30$ n. 15 .

266. 302 F. Supp. at 30. The Norfolk School Board had followed Professor Pettigrew's "principles" and drew its zones so that each integrated school would have a 60 to 70 per cent white majority. To do this, however, the Board had to leave 19 all-black elementary schools untouched. Approximately 76 per cent of the black elementary students would continue to attend these schools. 434 F.2d 408, $410-11$ (4th Cir. 1970).

267. 434 F.2d 408 (4th Cir.), cert. denied, 399 U.S. 929 (1970). In reversing, the circuit court indicated that it did not need to discuss the sociological data because where "[ $w$ ] hite schools remain predominantly white . . black schools remain black," there is a violation requiring an appropriate remedy. The "quota" was "the antithesis of a racially unitary system." Id at 411.

268. 429 F.2d 820 (4th Cir. 1970). 
Professor Pettigrew was hotly debated. Judge Craven's position was that in view of the serious threat of white flight-and, indeed, substantial white flight had already taken place- "some degree of moderation in selecting a remedy" was needed. ${ }^{269}$ Professor Pettigrew's testimony in Brewer v. Norfolk City School Board that the optimum ratio was 30 per cent black to 70 per cent white was cited with favor by Judge Craven. ${ }^{270}$

269. Id. at 822 . Judge Craven noted that in 1969 , when there were 2,408 black students and 256 white students enrolled in the schools of Clarendon County, S.C., 110 white students "fled the public school system in favor of a parochial private school," and 100 more applied for admission for the following fall. $I d$. Judge Craven stated that:

judges in fashioning remedies cannot successfully ignore reality. ... [S]ome degree of moderation in selecting a remedy is more likely to accomplish the desired result, a unitary, non-racial public school system, than is unyielding fidelity to the arithmetic of race. . .

The threat of flight from the public school system ordinarily should not be allowed to influence the selection of the plan or its judicial approval. It is relevant here only because the whites constitute such a small minority. ...

. [A] practical approach to the problem would ... greatly diminish the temptation to flee the system. . .

429 F.2d at $821-22$

Judge Sobeloff, in a separate concurring opinion, responded:

The dissenters agree that the Board's freedom of choice plan is deficient, but they consider the remedy too strong. As they point out, we are threatened in this case with an exodus of white students that tends to convert the court-ordered integration into an exercise in futility....

It would ... astonish the Brown court to learn that 16 years later . . it was seriously being contended that desegregation might not be required insofar as it threatened to impair majority white situations. . .

"White Flight" is one expression of resistance to integration, but the Supreme Court has held over and over that courts must not permit community hostility to intrude on the application of constitutional principles. . . [D]issidents who threaten to leave the system may not be enticed to stay by the promise of an unconstitutional though palatable plan. ... [T] he road to integration is served neither by covert capitulation nor by overt compromise ... . The purported restriction of the thesis to extreme white minority-white flight situations is really no limitation at all. Rather it offers a premium for community resistance. More to be feared than white flight in Clarendon County would be any judicial countenancing of the suggestion that abandoning or qualifying a desegregation program is a legally acceptable way to discourage flight.

429 F.2d at 824, 827. See also Craven, The Impact of Social Science Evidence on the Judge: A Personal Comment, 39 Law \& Contemp. Prob. no. 1, at 150, 154-55 (1975).

270. 429 F.2d at 821 n. 1 .

R. Crain \& C. Rossell, Evaluating School Desegregation Plans Statistically 18 (1973) proffer a similar thesis:

(1) That blacks benefit from attending schools which are over $50 \%$ white, but there is no additional benefit as the \% white increases beyond $70 \%$

(2) That whites benefit from interracial contact and a school must be at least $5 \%$ black to provide these benefits.

(3) Social and Political constraints make it inadvisable to bring black students into allwhite schools in excess of $30 \%$ of the enrollment ... [although] no educational research which demonstrates that a $70 \%$ white school is superior to a $50 \%$ white school.

A number of districts have developed desegregation plans providing for a 70 to 30 per cent whiteblack mix, leaving behind in all-black schools what Professor Gordon Foster has referred to as "surplus" blacks. He notes that this has become known as the "warehousing" technique, because the remaining all-black schools are often warehouse-like structures in the middle of the ghetto.

G. Foster, November 9. 1974 (paper prepared for conference sponsored by United States Com- 
The federal courts, when plunged into sociology and educational theory, are into something they know very little about. Dr. Thomas F. Pettigrew of Harvard University, who has a respectable social-psychology pedigree and who is a recognized expert in school integration, testified at great length about integration and desegregation in Brewer v. Norfolk City School Board. . . .

Dr. Pettigrew ... testified that "there does seem to be some optimum level for the achievement of both white and black children that drops after 35 or 40 [percent black students in the school is surpassed]." Dr. Pettigrew has concluded that little advantage is gained for children of either race, and some harm may result, from placing children in a school where they are in a distinct racial minority. .. .

Judge Sobeloff responded by saying that "short shrift" should be given to Dr. Pettigrew's testimony. ${ }^{271}$

[The] central proposition [of Pettigrew's thesis] is that the value of a school depends on the characteristics of a majority of its students and superiority is related to whiteness, inferiority to blackness. Although the theory is couched in terms of "socio-economic class" and the necessity for the creation of a "middleclass milieu," nevertheless, at bottom, it rests on the generalization that, educationally speaking, white pupils are somehow better or more desirable than black pupils. This premise leads to the next proposition, that association with white pupils helps the blacks and so long as whites predominate does not harm the white children. But once the number of whites approaches minority, then association with the inferior black children hurts the whites and, because there are not enough of the superior whites to go around, does not appreciably help the blacks.

....

The inventors and proponents of this theory grossly misapprehend the philosophical basis for desegregation. It is not founded upon the concept that white children are a precious resource which should be fairly apportioned. It is not, as Pettigrew suggests, because black children will be improved by association with their betters. . . [S]chool segregation is forbidden simply because its perpetuation is a living insult to the black children and immeasurably taints the education they receive. This is the precise lesson of Brown. Were a court to adopt the Pettigrew rationale it would do explicitly what compulsory segregation laws did implicitly.

In United States $v$. Board of School Commissioners, the district court has noted that in Indianapolis, a city where the majority of the black population was already confined to the inner city, "white flight" would become accelerated and irreversible when the percentage of black pupils in a particular school ap-

mission on Civil Rights, Washington, D.C.). See, e.g., Northcross v. Board of Educ., 489 F.2d 15 (6th Cir. 1973), cert. denied, 416 U.S. 962 (1974).

271. 429 F.2d 820, 824, 826 (4th Cir. 1970). Judge Sobeloff suggests that the Pettigrew plan is just as invidious when considered from the class rather than the racial aspect:

[E]ven apart from its racial aspect, the Pettigrew plan would be constitutionally illegitimate. . . The goal of social class segregation is scarcely more defensible than that of racial segregation .... Viewing the matter on a policy level, a country as sadly riven as ours stands in no need of additional polarizing projects. From a constitutional standpoint, a program of apartheid according to social class is as impermissible as avowed racial separation-and as repugnant to the Equal Protection Clause. Our constitution does not permit the insulation of whites from blacks, rich from poor, high class from low class.

429 F.2d at 826 . 
proached 40 per cent, thus leaving a nearly all-black school system. ${ }^{272}$ The court-citing the situation in Atlanta as an example-cautioned that a school board, by implementing a desegregation plan that failed to take this "tipping factor" into account, could become indirectly responsible for pushing the racial balance past the "tipping point," resulting in the rapid resegregation of the schools. ${ }^{273}$ However, on appeal, the Seventh Circuit responded that " $[\mathrm{s}] \mathrm{o}-\mathrm{called}$ 'white flight' is not an acceptable reason for failing to dismantle a dual school system.",274

In Calhoun $v$. Cook, the district court noted the precipitous speed of the "tipping process." 285

The white students remaining are concentrated at the extreme northern and southern ends of the district, while the vast middle is a broad belt of industry and high-density solid black housing. The line between these areas is steadily creeping towards the ends, with increased black housing and diminished white housing. Since 1961, [the school board] has annually achieved substantial temporary integration by the establishment or construction of "line schools." However, 34 of those schools have gone from all-white to $90 \%$ or more black during the period. This "tipping process" is so rapid that it sometimes occurs by the time a facility deliberately located to increase integration can be completed and occupied. Seldom does it last longer than two years....

Thus, according to the court, wholesale busing was "unworkable."

The court observed that "Atlanta now stands on the brink of becoming an all-black city. A fruit-basket turnover through busing to create a $30 \%$ white- $70 \%$ black uniformity throughout the system would unquestionably cause such a result in a few months time." 276

The question of whether and when there is a tipping point has been raised most often in connection with racial discrimination in housing. Most of the literature indicates that the tipping point will vary-from as low as 6 per cent to

272. United States v. Board of School Comm'rs, 332 F. Supp. 655, 676-77 (S.D. Ind. 1971), aff'd, 474 F.2d 81 (7th Cir.), cert. denied, 413 U.S. 920 (1973). District Court Judge Dillin noted in his opinion only that evidence in the case as to the existence of a "tipping point" of 40 per cent black pupils was "undisputed." 332 F. Supp. at 676. Judge Dillin again addressed himself to "tipping," citing evidence showing that in the Indianapolis schools, white flight had become problematical as the percentage of black pupils reached 25-30 per cent. $368 \mathrm{~F}$. Supp. 1191, 1197-99 (S.D. Ind. 1973). It was partially this concern with the possibility of resegregation that led the district court to include the Greater Indianapolis area in its remedy. On appeal, the Seventh Circuit reversed that part of the district court's decision relating to a metropolitan remedy beyond the boundaries of the county in which Indianapolis is located, and vacated and remanded that part of the remedy that ran to the county boundaries for further findings. $503 \dot{\mathrm{F}} .2 \mathrm{~d} 68$ ( 7 th Cir. 1974). See also the textual discussion at p. 110 infra.

273. 332 F. Supp, at 677.

274. 503 F.2d 68, 80 (7th Cir. 1974). Cf. Monroe v. Board of Comm'rs, 391 U.S. 450 (1968), involving a "free transfer" option-defended by the school board on the ground that it would prevent "white flight." The Court found that the plan acted to resegregate the system and, in striking down the free transfer option plan, responded to the "white flight" argument by quoting from Brown II: "[I]t should go without saying that the vitality of these constitutional principles cannot be allowed to yield simply because of disagreement with them." Id. at 459 .

275. 332 F. Supp. 804, 806 (N.D. Ga. 1971).

276. 332 F. Supp. at 808 . 
as high as 50 per cent, depending upon many factors, including the "intensity of prejudicial feeling in the community." 277 The use of the "tipping point" as the upper limit for a "benign" quota system has been proposed on occasion - the justification being that minorities would benefit in that their feelings of rejection, prompted by their living in separation from the rest of the community, would be eliminated. ${ }^{278}$

The Supreme Court, in Wright v. Council of the City of Emporia, ${ }^{279}$ recognized the phenomenon of "white flight," but not in the context of minimizing the impact of a desegregation plan by compromising it in an effort to retain whites who might flee if there were total desegregation. Instead, the Court prohibited a city from withdrawing from an existing county school district when the combined system was still under a federal court order to desegregate. The dual school system which had been found to violate the constitution was the single city-county unit and therefore it was proper to treat it as a single unit for the purpose of dismantling that system. ${ }^{280}$ The possibility of "white flight" from the county system to the proposed city school system was one of the factors the Court felt "would actually impede the process of dismantling the existing dual system." 281 And in United States v. Scotland Neck City Board of Education, the Supreme Court reiterated its stand that "while [white flight] may be cause for deep concern to the [school boards], it cannot . . . be accepted as a reason for achieving anything less than complete uprooting of the dual public school

277. See, e.g., Mulvihill, Problems in the Management of Public Housing, 35 TEMP. L.Q. 163, 175-78 (1962) (6 to 50 per cent depending upon "the intensity of prejudicial feeling in the community, the extent of private housing to which white tenants can escape and the racial composition of the neighborhood"); LeBlanc, Race, Housing, and the Government, 26 VAN D. L. Rev. 487, 502-04 (1973) (tipping point 40 per cent); Note, Racial Discrimination in Housing, 107 U. PA. L. Rev. 515, 538-39 (1959) (6 to 50 per cent depending upon differing opinions of "guestimators" and the fact that individual tipping points will vary among housing projects).

As to school desegregation and tipping points, see R. Wegmann, Neighborhoods and Schools in Racial Transition, April 1, 1975 (paper presented at American Educational Research Association, Washington, D.C.). Wegmann, a sociologist, states that desegregating any urban school system where the total black enrollment runs much above 30 per cent will be futile because of "tipping"- white families move out when blacks in the neighborhood school reach some point between 30 and 50 per cent of the student population.

See also, J. Coleman, Trends in Racial Segregation in Schools, 1968-73, April 2, 1975 (paper presented at American Educational Research Association, Washington, D.C.). Professor Coleman argues for more research into white reaction and other indirect effects of desegregation in order to develop alternative strategies. He notes that in refusing to recognize white flight, the courts in the long run will be responsible for separating whites and blacks even more than at present. But see the statement by state Superior Court Judge Max F. Deutz of California that the "tipping" in Inglewood-a suburb of Los Angeles whose enrollment had gone from 60 per cent European American to 80 per cent minority-had begun before his integration order, issued five years ago: "Some people say the plan caused it, and it might have been a factor, but certainly not the predominant factor." N.Y. Times, May 11, 1975, $\$ 1$, at 26, col. 1.

278. Mulvihill, supra note 277 , at 177 .

279. 407 U.S. 451 (1972). See also United States v. Scotland Neck City Bd. of Educ., 407 U.S. 484 (1972); Monroe v. Board of Comm'rs, 391 U.S. 450, 459 (1968).

280. 407 U.S. at $459-60$.

281. 407 U.S. at 466 . 
system." ${ }^{282}$ Although this language has been picked up by the circuits as indicating that white flight cannot under any circumstances be a consideration in formulating a remedy, ${ }^{283}$ the Supreme Court has not yet addressed itself to this issue in any broad sense.

\section{Metropolitan Area Remedies}

When, if ever, may school district lines be disregarded in devising remedies to disestablish an unconstitutional dual school system? Metropolitan areas in which the central city loses total population to the suburban ring while the minority population within the central city increases, are becoming more and more the typical situation. The proportion of minority students in the central city school district is increasing even more rapidly than the total minority population. Thus, the "growing core of Negro schools [is] surrounded by a receding ring of white schools." 284 As the proportion of blacks in the central cities increases, it becomes more and more futile to order a desegregation plan which is confined to the city limits inasmuch as there is or will be no one left with whom to integrate. ${ }^{285}$ Thus a number of school desegregation suits have sought a metropolitan area remedy.

There are three types of cross-district or interdistrict organizational arrangements which have come before the courts. One involves the formation of a single "super district" by consolidating contiguous districts in the metropolitan area-the remedy proposed by the district court in Bradley v. School Board, the Richmond case. ${ }^{286}$ The second involves redistricting the metropolitan area into new units which facilitate the reduction of racial imbalance-represented by what the district court and the Sixth Circuit attempted to do in Milliken $v$. Bradley, the Detroit case. ${ }^{287}$ Finally, what may be yet another type is represented by the proposed merger of the city of Louisville and its suburban county. ${ }^{288}$

282. 407 U.S. 484.491 (1972).

283. United States v. Board of School Commirs, 503 F.2d 68.80 (7th Cir. 1974).

284. Milliken v. Bradley, 418 L.S. 717.799 (1974) (Marshall, J., dissenting).

285. Judge Deutz of the Los Angeles Superior Court has recently permitted a five-year old desegregation busing plan for Inglewood to be discarded because "As a practical matter we are now busing black children from predominantly black schools to other predominantly black schools." N.Y. Times, May 11. 1975. \$ 1, at 26, col. 1.

286. 338 F. Supp. 67 (L.D. Va.). mid. 462 F.2d 1058 (4th Cir. 1972), affd by an equally divided Court. 412 U.S. 92 (1973). The remedy sought here would have joined two counties (Henrico and Chesterfield) with the (ity of Richmond. District Judge Merhige adopted Richmond's metropolitan plan, prepared under the direction of Dr. Thomas Little, Associate Superintendent of the Richmond City Schools, 338 F. Supp. at 186, which provided for a single school board of no more than nine members or less than six to preside over the three-county "super district." Id. at 245. For administrative purposes, however. the consolidated system was to be divided into six sub-units. Administration and curriculum decisions would be delegated to the subdivision heads. Id. at 191. 287. 345 F. Supp. 914 (E.D. Mich. 1972), affd, 484 F.2d 215 (6th Cir. 1973), rrid, 418 U.S. 717 (1974). In this case. 53 school districts or parts of school districts were to be joined with sections of the Detroit school district so as to form fifteen new "clusters." 345 F. Supp. at 928-29.

288. Newburg Area Council. Inc. v. Board of Educ.. 489 F.2d 925 (6th Cir. 1973), vacated and 


\section{1. "Super Districts"}

Under what circumstances may one of the above interdistrict arrangements be ordered? In formulating a desegregation plan for Richmond, the district court was concerned with maintaining a "viable racial mix"289 in the schools, and therefore desired a plan that would not accelerate white flight from the largely (over 70 per cent) black Richmond schools to the predominantly (over 90 per cent) white schools in the two neighboring counties. ${ }^{290}$ The district court concluded that these circumstances justified the joinder of the two outlying counties in its desegregation decree, without requiring proof either that the county boundaries had been drawn with intent to segregate or that the counties had acted in such a way so as to render them responsible for the city's segregation. ${ }^{291}$

The Fourth Circuit, however, reversed the decision, holding that the district court could not consolidate school districts without proof that the actions of authorities in the outlying counties were taken with segregative intent and effect. $^{292}$ There was no proof that "the [outlying] counties were . . keeping blacks in Richmond schools while allowing whites to flee . . ."293

The Fourth Circuit admitted evidence of housing discrimination as relevant to the case, but required greater evidence of complicity among the three units-for the purpose of keeping blacks in Richmond and out of the suburbs-before it would find such discrimination sufficiently related to schools as to support a finding of a unified three-county violation of the fourteenth amendment. ${ }^{294}$ Thus the circuit court appears to accept the finding that all three units had participated in massive housing segregation, yet each unit was seen to have segregated independently of the other two for the general purpose of racial discrimination and not for the specific purpose of discrimination against Richmond blacks to keep them in Richmond schools. The court went on, however, to say that ${ }^{295}$

the root causes of the concentration of blacks in the inner cities of America are simply not known .... [Any action] the counties may seem to have taken to keep blacks out is slight indeed compared to the myriad reasons, economic, political and social, for the concentration of blacks in Richmond and does not support the conclusion that it has been invidious state action which has resulted in the racial composition of the three school districts. . .

The court, in taking the position that "economic, political and social" reasons can explain the concentration of blacks in Richmond, was flying in the

remanded, 418 U.S. 918 (1974), on remand, 510 F.2d 1358 (6th Cir. 1974), cert. denied, 95 S. Ct. 1658 (1975).

289. 338 F. Supp. at 184 .

290. 338 F. Supp. at $184-86$.

291. 338 F. Supp. at 100 .

292. 462 F.2d 1058, 1069 (4th Cir. 1972).

293. 462 F.2d at 1065 .

294. 462 F.2d at $1065-66$.

295. 462 F.2d at 1066 . 
face of much of the evidence in the record with regard to the widespread existence of racial residential discrimination. ${ }^{296}$ For example, Dr. Karl Taeuber, professor of sociology at the University of Wisconsin, testified that his analysis of the census data led him to conclude that about 85 per cent of the pervasive segregation extant in metropolitan areas, including Richmond, was caused by publicly and privately enforced racial discrimination rather than low income. ${ }^{297}$ Martin Sloane, then acting deputy staff director of the U.S. Civil Rights Commission, with broad experience in federal housing policies, testified that much of the urban and, consequently, public school segregation, could be attributed to federal housing policies, e.g., FHA insurance or racially-restricted developments. ${ }^{298}$ The testimony of the executive directors of the Richmond Redevelopment and Housing Authority and of the Richmond Regional Planning District Commission supported Mr. Sloane's testimony. ${ }^{29 y}$ Yet, to the Fourth Circuit, this type of evidence was deemed insufficient to establish the requisite intentional segregative actions by other governmental agencies. The circuit court noted that ${ }^{300}$

\section{[w] hatever the basic causes [of the concentration of blacks in the inner city] it has not been school assignments, and school assignments cannot reverse the trend. That there has been housing discrimination in all three units is deplora- ble, but a school case, like a vehicle, can carry only a limited amount of bag- gage.}

And whatever may have been the situation in the past with regard to school desegregation, the three districts were now seen as operating unitary school systems. ${ }^{301}$

The circuit court further noted that the county boundaries had not changed significantly for over one hundred years and stated that this history was not to be ignored. ${ }^{302}$ Since the majority saw no constitutional violation (treating each of the three systems separately and finding each unitary), clearly the district court could not override the "states' near plenary power over its political subdivisions." ${ }^{303}$ On appeal to the Supreme Court, ${ }^{304}$ Justice Powell did not participate in the case and the remaining justices divided evenly. This 4-4 stalemate meant that the Fourth Circuit's decision was allowed to stand.

\section{Redistricting the Metropolitan Area}

The first interdistrict case actually to be decided by the Supreme Court was Milliken v. Bradley (the Detroit case). ${ }^{305}$ This case was the first instance in which

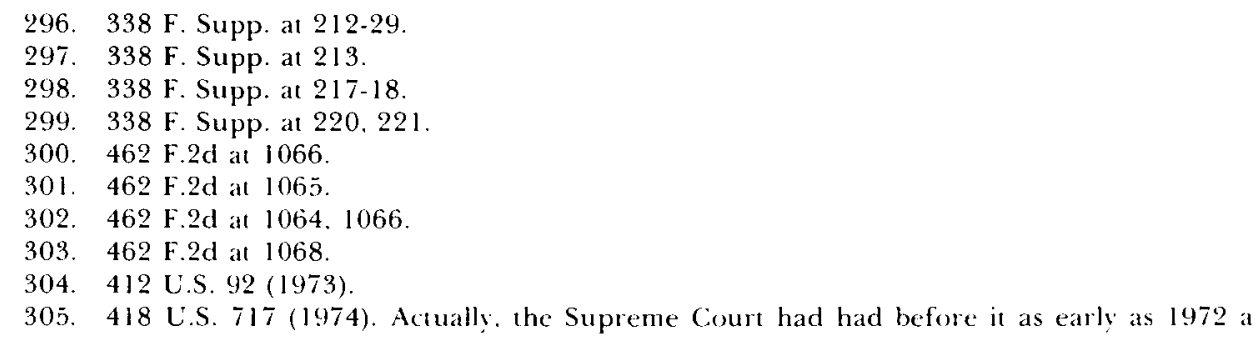


the Supreme Court reversed a lower court order which, after having found unconstitutional segregation, had sought to bring about greater integration. ${ }^{\mathbf{3 0 6}}$ The Court gave its endorsement to the position taken by the Fourth Circuit in the Richmond case-that plaintiffs would have to prove, before interdistrict remedies could be ordered, that actions were taken with deliberate segregative intent by the outlying, predominantly white districts, and that these actions had an effect on the segregation within the city. ${ }^{307}$

\section{a. The Finding of De Jure Segregation}

It should be noted that the situation involved in the Detroit case is somewhat different from that involved in the Richmond case. In the latter case, the Fourth Circuit found that each of the three school districts involved in the proposed interdistrict remedy had previously dismantled their former dual systems and were operating unitary systems. ${ }^{308}$ In the Detroit case, the district court found that the Detroit School District was de jure segregated, ${ }^{309}$ and this aspect of the case was not questioned by the Supreme Court. ${ }^{310}$

The district court's holding with respect to de jure segregation was based on its finding that Detroit school officials had engaged in de jure acts of discrimination, including the drawing of attendance zones to minimize integration and the maintenance of optional attendance zones, the busing of black pupils beyond closer white schools with available space, and the selection of sites for

desegregation case in which an interdistrict remedy was sought. In Spencer v. Kugler, 326 F. Supp. 1235 (D.N.J. 1971), aff'd mem., 404 U.S. 1027 (1972), which arose in New Jersey, the plaintiffs alleged that segregation of the school system was attributable to New Jersey statutes which made school district boundaries coterminous with municipal boundaries. $326 \mathrm{~F}$. Supp. at 1240-41. The three-judge district court, however, found this coterminality was "reasonable" in light of the municipal taxing authority. 326 F. Supp. at 1241 . The system was unitary and any racial imbalance within a local school district resulted from an imbalance in the population of that district. Id. at 1243.

The court also pointed to the fact that the Supreme Court, in Swann, had distinguished

between those states which have a history of dual school systems and a separation of the races continued through the use of "freedom-of-choice" and "geographical zoning" plans which create the illusion of conforming to the law, and those wherein so-called "de-facto" segregation results from housing patterns and conventional drawing of school district zones.

326 F. Supp. at 1242.

The Supreme Court summarily affirmed without oral argument, 404 U.S. 1027 (1972), with Justice Douglas dissenting on the ground that redistricting of school districts, by analogy to the reapportionment cases, should be an available remedy where there is racial imbalance-ciuing Reynolds v. Sims, 377 U.S. 533 (1964).

306. As noted in note 78 supra, the Supreme Court split evenly on the Richmond case, thus letting the Fourth Circuit decision stand.

307. 418 U.S. at $744-45$.

308. Bradley v. School Bd., 462 F.2d 1058, 1065 (4th Cir. 1972), aff'd by an equally divided Court, 412 U.S. 92 (1973).

309. Bradley v. Milliken, 338 F. Supp. 582, 592 (E.D. Mich.), supplemented by 345 F. Supp. 914 (E.D. Mich. 1971), affd, 484 F.2d 215 (6th Cir. 1973), rev'd, 418 U.S. 717 (1974).

310. The Supreme Court opinion merely noted that the findings of the district court as to de jure segregation appeared correct. 418 U.S. at $738 \mathrm{n}$. 18. Thus, in the Detroit case-the second northern case to come before the Supreme Court-the Court was unanimous in finding intradistrict discrimination. This is a clear indication that as far as intradistrict discrimination is concerned, the Detroit decision has done nothing to undermine Suann or Keyes. 
school buildings. ${ }^{311}$ The district court also found state involvement in actions which maintained segregation in the Detroit school system, looking to a number of factors, including the pattern of residential segregation: ${ }^{312}$

Governmental actions and inaction at all levels, federal, state and local, have combined, with those of private organizations, such as loaning institutions and real estate associations and brokerage firms, to establish and maintain the pattern of residential segregation throughout the Detroit metropolitan area.

The court then found that "[t]he State and its agencies, in addition to their general responsibility for the supervision of public education, have acted directly to control and maintain the pattern of segregation in the Detroit schools." ${ }^{13}$ To support this finding the court noted that: ${ }^{314}$

(1) state transportation services were lesser in quality and quantity in Detroit than in white suburbs, thus limiting pupils' choices to attend other schools.

(2) "other financial limitations, such as those on bonding and the working of the state aid formula" perpetuated segregated schools. ${ }^{315}$

(3) the passage of Act 48 acted to "impede, delay and minimize racial integration." 316

As to this last factor, the Detroit Board of Education had adopted a plan on April 7, 1970 which provided for changes in some of the high school attendance zones, designed to effect a more balanced ratio of black and white students at the senior high school level. ${ }^{317}$ Following the adoption of the plan, the Michigan legislature enacted a statute which provided that the Detroit plan be suspended and that a neighborhood school policy be instituted. ${ }^{318}$ The Sixth Circuit had previously held this section of the act unconstitutional. ${ }^{319}$ The Sixth Circuit concluded twenty-one pages of discussion of the evidence supporting the district court's findings of constitutional violations by noting that ${ }^{320}$

[t]his record contains a substantial volume of testimony concerning local and State action and policies which helped produce residential segregation in Detroit and in the metropolitan area of Detroit. In affirming the District Judge's findings of constitutional violations by the Detroit Board of Education and by the State defendants resulting in segregated schools in Detroit, we have not

\footnotetext{
311. 338 F. Supp. at 592

312. 338 F. Supp. at 587

313. 338 F. Supp. at 589

314. Id.

$315 . \quad I d$.

316. Id.

317. See testimony of Dr. Norman Drachler, Superintendent of the Detroit Public Schools, quoted in Bradley v. Milliken, 433 F.2d 897, 898-99 (6th Cir. 1970).

318. No. 48, \$ 12, [1970] Mich. Public Acts 139-40. The antithesis of local control would seem to be the state legislature telling the local district how to assign its pupils. See discussion in the text at pp. $111-14$ infra.

319. Bradley v. Milliken, 433 F.2d 897, 902 (6th Cir. 1970).

320. 484 F.2d 215, 242 (6th Cir. 1973).
} 
relied at all upon testimony pertaining to segregated housing except as school construction programs helped cause or maintain such segregation.

The circuit court found that "[t]he discriminatory practices on the part of the Detroit School Board and the State of Michigan revealed by this record are significant, pervasive and causally related to the substantial amount of segregation found in the Detroit School System by the District Judge."321

\section{b. The Metropolitan-wide Remedy}

After the first Detroit decision, in which the district judge found de jure segregation to exist, the court issued a directive to city and state defendants to submit desegregation plans, both Detroit-only (to be submitted by the city) and metropolitan (to be submitted by the state). ${ }^{322}$ When the plans were presented, the district judge rejected all three Detroit-only plans, noting that "relief of segregation in the public schools of the City of Detroit cannot be accomplished within the corporate geographical limits of the city." 323 Thus the district court's finding that the state was involved in maintaining segregation in Detroit's schools coupled with the fact that any Detroit-only plan would lead very shortly to an all-black Detroit School District, led the judge to the conclusion that only a metropolitan remedy would be appropriate. ${ }^{324}$ The Sixth Circuit agreed. ${ }^{325}$ But the Supreme Court found that there was no evidence that the acts of suburban school districts had brought about the segregation in the Detroit School District, ${ }^{326}$ and therefore reversed. Thus an interdistrict violation is necessary before an interdistrict remedy can be ordered. ${ }^{327}$ Chief Justice Burger articulated the principle as follows: "the scope of the remedy is determined by the nature and extent of the constitutional violation." 328

The basic standards which are to govern the use of cross-district remedies are as follows: ${ }^{329}$

Before the boundaries of separate and autonomous school districts may be set aside by consolidating the separate units for remedial purposes or by imposing a cross-district remedy, it must first be shown that there has been a constitutional violation within one district that produces a significant segregative effect in another district. Specifically it must be shown that racially discriminatory acts of the state or local school districts, or of a single school district have been a substantial cause of

321. Id. at 241 (emphasis added).

322. Unreported directive (E.D. Mich. Oct. 4, 1974), discussed at 345 F. Supp. 914, 916, 920-21. See also 484 F.2d $215,218,220-21 ; 418$ U.S. 717 , at 729-33.

323. Unreported findings of fact and conclusions of law (E.D. Mich. Mar. 28, 1972), quoted at 484 F.2d at 244.

324. Id., quoted at 484 F.2d at 243-44.

325. 484 F.2d 215,249 (6th Cir. 1973).

326. 418 U.S. 717,752 (1974). In fact, the district court had explicitly stated that it had not even considered any evidence as to the actions of the suburban school districts. 345 F. Supp. 914, 920 (E.D. Mich. 1971 )

327. 418 U.S. at 752 .

328. 418 U.S. at 744 .

329. 418 U.S. at $744-45,749$ (emphasis added). 
inter-district segregation. . . [W]ithout an inter-district violation and inter-district effect, there is no constitutional wrong calling for an inter-district remedy.

... Where the schools of only one district have been affected, there is no constitutional power in the courts to decree relief balancing the racial composition of that district's schools with those of the surrounding districts.

The Court left the door only slightly ajar on interdistrict remedies: ${ }^{330}$

[A]n interdistrict remedy might be in order where the racially discriminatory acts of one or more school districts caused racial segregation in an adjacent district, or where district lines have been deliberately drawn on the basis of race.

There was evidence that a predominantly black suburb, which had no high school, sent its high school age students to schools in Detroit-with the "tacit" approval of the State Board of Education-because the nearby white suburbs refused to accept these students. ${ }^{331}$ While this would appear to come within the above guidelines, the Court said that this was only an "isolated instance" which could not justify a broad metropolitan-wide remedy. ${ }^{332}$ The Court thus found that evidence of state involvement, such as the discriminatory provision of transportation costs, state legislation rescinding a voluntary desegregation plan drawn up by the Detroit school board, cooperation with Detroit officials in school construction policies which fostered segregation, and approval of the busing of black suburban students to Detroit schools was insufficient for a metropolitan-wide remedy.

There would seem to be no established principle of constitutional law requiring the Court to reject the notion that the state, which draws the boundary lines, has no responsibility for the segregated pattern of housing and schooling. Nor is there settled constitutional law which dictates that there is no affirmative duty to correct interdistrict segregation. But it seems clear that to the Milliken majority, a "unitary" system can be an all-black system contained within its state-created borders. The Court noted that it has only been in the context of a single "geographic and administrative school system" serving both white and black students that the terms "unitary," "dual," and "racially identifiable" schools have had meaning. ${ }^{333}$ But nothing in those earlier cases suggested that a stricter test or standard would be required to cross district lines than to cross attendance zones or neighborhoods. The Court failed to explain why the standard articulated in Davis ${ }^{\mathbf{3 3 4}}$ had to be restricted to the boundaries of a school district: ${ }^{335}$

Having once found a violation, the district judge . . should make every effort to achieve the greatest possible degree of actual desegregation, taking into

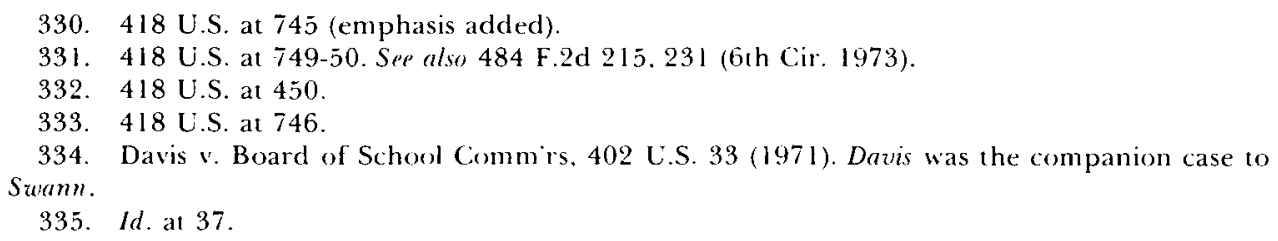


account the practicalities of the situation. A district court may and should consider the use of all available techniques .... The measure of any desegregation plan is its effectiveness.

Nor does the Court explain why remedies which could be "administratively awkward, inconvenient and even bizarre" within a district, could not run past the district line. ${ }^{336}$ In Justice White's view, the Court had ${ }^{337}$ "fashion[ed] out of whole cloth an arbitrary rule that remedies for constitutional violations occurring in a single Michigan school district must stop at the school district line."

Neither the majority nor Justice Stewart in his concurring opinion explained why the standards used in the Denver case for determining the violation and its remedy did not apply in Detroit. In the Denver case, the Court presumed that de jure segregation in one area spread to or infected other contiguous areas, shifting the burden to the defendants to prove it did not. ${ }^{338}$ Using the same approach in the Detroit case, the finding of de jure segregation in a "meaningful portion" of the metropolitan area (the central city) should trigger a presumption either that there is a reciprocal segregative effect in the suburbs or that (State) school authorities have engaged in intentional segregative actions throughout the metropolitan area. ${ }^{339}$

In the Detroit case, however, the burden was upon the plaintiffs to prove that de jure acts of (a significant number?) of suburbs have had a segregative effect on Detroit, or that the state drew district boundary lines to contain Detroit. ${ }^{340}$ But not only the burden of proof had shifted. As has already been noted, in the Denver case the remedy was not limited to that part of the district where the past segregative acts were shown to have occurred; a district-wide remedy_ “all-out desegregation"341_-was triggered.

The remedy and the violation thus appear to have become entangled in the Detroit case, and are no longer separate concepts. The Court seems to be adopting a "culpability" theory; that is, there is no interdistrict violation unless the suburban districts engaged in deliberate segregative acts affecting the degree of segregation in Detroit or the state was involved in deliberately containing Detroit's blacks above and beyond just being responsible for acts of its agent - the Detroit School Board-or even for maintaining existing boundaries where the natural and foreseeable consequence was the isolation of blacks in Detroit. ${ }^{342}$

Pursuing the "culpability" theory a little further, however, it becomes evident that the Court believed that since the suburban white residents and their

336. Swann v. Charlotte-Mecklenburg Bd. of Educ., 402 U.S. 1, 28 (1971).

337. 418 U.S. at 768 (White, J., dissenting).

338. 413 U.S. 189, 201-03, 208-12 (1973). Cf. United States v. Texas Educ. Agency, 467 F.2d

848,888 (5th Cir. 1972) (Wisdom, J., dissenting). ("Infection at one school infects all schools.")

339. See notes 74-80 and accompanying text at pp. 63-64 supra.

340. 418 U.S. at 746.

341. Keyes v. School Dist. No. 1, 413 U.S. 189, 214 (1973).

342. See text at pp. 66-69 supra. 
children were not "guilty" or responsible for the "growing core of Negro schools," they should not be "punished" by forcing them to become part of the remedy. This does not explain, however, why white parents and their children are any more deserving of "punishment" because they live in Denver or in Charlotte rather than in the suburbs of those cities. The approach taken by the Court $^{343}$ in this case may serve to increase white flight from the cities by indicating that the suburbs will be a "safe haven" for those who otherwise would be caught up in a desegregation decree. Although having previously prevented a new school district from forming "where its effect would be to impede the process of dismantling a dual system" by encouraging white flight, ${ }^{344}$ the Court has now ensured that white flight will proceed even more rapidly from Detroit than heretofore has been the case.

\section{c. Proving Racial Containment}

After the Detroit case, what must plaintiffs be able to demonstrate for a metropolitan area remedy? It is not sufficient that de jure segregation exists in one district and that no effective plan for desegregation could be devised without going beyond the borders of that district. It is not sufficient to show that for certain purposes, the metropolitan area should be treated as a unit. It is not sufficient to show that there is a de jure violation in only one other district in the metropolitan area as that would only be an "isolated instance." It may not even be sufficient to show de jure segregation in several districts as it appears that plaintiffs will have to show that segregation in one district resulted from discriminatory actions by officials in other-the suburban-school districts or by state education officials.

If plaintiffs cannot readily show that the actions of state or suburban school officials contributed to the segregation of the schools within the central city, can plaintiffs establish a prima facie case for interdistrict relief by proving segregative actions by other governmental agencies? In other words, if plaintiffs could show that governmental policies in housing and zoning, employment, and welfare in one district produced a significant segregative effect in another district, would this justify an interdistrict remedy?

The majority opinion in the Detroit case seems to suggest that suburban districts could be included in a court-ordered desegregation plan only if school officials have been responsible for the de jure segregation in Detroit. If that is true, plaintiffs have an almost impossible burden. In a footnote, however, the majority notes that since the circuit court expressly noted that its decision did not rest on any of the testimony with regard to segregated housing, "the case

343. Justice Stewart, in his concurring opinion, expressed somewhat the same view-that the proposed remedial decree approved by the Sixth Circuit would "include schools and school children in many other school districts that have presumptively been administered in complete accord with the Constitution." 418 U.S. at 755.

344. Wright v. Council of the City of Emporia, 407 U.S. 451,470 (1972). 
does not present any question concerning possible state housing violations." 345 Thus the door may be open to future plaintiffs to show that "the State, along with private persons, [has] caused, in part, the housing patterns of the . . metropolitan area which, in turn, produced ... [segregated] neighborhoods ...."346

For the majority, then, there was no need to examine the trial record to determine whether governmental policies in housing acted to contain blacks in Detroit. Justice Stewart, however, did examine the record, and found that it did not show that "the racial composition of the Detroit school population or that residential patterns within Detroit and in the surrounding areas were in any significant measure caused by governmental activity . . ."347 But it is clear that, to Justice Stewart, proof of such actions by other governmental agencies would, in certain circumstances permit an interdistrict remedy: ${ }^{\mathbf{3 4 8}}$

Were it to be shown, for example, that state officials had contributed to the separation of the races . . by purposeful, racially discriminatory use of state housing or zoning laws, then a decree calling for transfer of pupils across district lines or for restructuring of district lines might well be appropriate.

Justice Stewart asserts that in the Detroit case, no evidence was introduced concerning the actions of suburban school districts other than that they had a much larger proportion of white students than did Detroit. This alone was not, in his view, sufficient to justify an interdistrict remedy. The plaintiffs must show "that such disparity was imposed, fostered, or encouraged by the state or its political subdivisions ...." "349 Thus, in Justice Stewart's view, there was no evidence of a constitutional violation (outside of Detroit) and Justice Marshall, in his dissent, was incorrect in saying that black children in Detroit had been confined by (external) intentional acts of segregation. ${ }^{350}$

[S]egregative acts within the city alone cannot be presumed to have produced-and no factual showing was made that they did produce-an increase in the number of Negro students in the city as a whole. It is this essential fact of a predominantly Negro school population in Detroit-caused by unknown and perhaps unknowable factors such as in-migration, birth rates, economic changes, or cumulative acts of private racial fears-that accounts for the "growing core of Negro schools," a "core" that has grown to include virtually the entire city. The Constitution simply does not allow federal courts to attempt to change that situation unless and until it is shown that the State, or its political subdivisions, have contributed to cause the situation to exist.

The problem is that Justice Stewart does not make very clear what evidence of other governmental activities would be sufficient. In the Richmond case, plaintiffs had presented extensive evidence of governmental actions which had

345. 418 U.S. at 728 n. 7.

346. Id.

347. 418 U.S. at 756 n. 2 (Stewart, J., concurring).

348. 418 U.S. at 755 .

349. Id.

350. 418 U.S. at 756 n. 2. But see 418 U.S. at 799 n. 19 (Marshall, J., dissenting). 
contributed to the "growing core of Negro schools," 351 yet it seems probable that Justice Stewart was one of the four votes against the plaintiffs in that case. ${ }^{352}$. Moreover, a respectable number of social scientists would not agree that the causes of the "growing core of Negro schools" are "unknown and perhaps unknowable." They could readily point out factors which explain the demographic patterns which give rise to a "growing core of Negro schools." 353

\section{City-County Consolidations}

The most significant case to deal with interdistrict remedies to date, in view of the fact that it was decided after the Supreme Court decision in the Detroit case is Newburg Area Council v. Board of Education.$^{354}$ Indeed, the initial decision in that case was appealed to the Supreme Court just as the Detroit case was being decided.$^{355}$ Rather than overturn the Louisville decision at that time, the Supreme Court remanded it to the Sixth Circuit, asking it to reconsider the case in light of Milliken $v$. Bradley. ${ }^{356}$ The Sixth Circuit did reconsider the case and concluded that the problem in Milliken had been that the remedy "was broader than the constitutional violation." 357 By contrast, in the Louisville case-where the city school district has a pupil population that is 50 per cent black and Jefferson County (in which Louisville is located) has a pupil population only 4 per cent black-"the situation presented is that of two districts in

351. Bradley v. School Bd., 338 F. Supp. 67, 84-100 (E.D. Va. 1972); Taylor, The Supreme Court and Urban Reality: A Tactical Analysis of Milliken v. Bradley, 21 WAYNe L. Rev. 751, 765-69 (1975).

352. The decision was affirmed by an equally divided Court, Justice Powell not participating, 412 U.S. 92 (1973). The four votes for plaintiffs were probably the same four who dissented in the Detroit case.

353. See, e.g., Natronal Comm. Aganst Discrimination in Housing and The Urban Land Institute, fair Housing and Exclusionary Land Use (1974); U.S. Commission on Civil Rights, Equal Opportunity in Suburbia (1974); M. Sloan, Milliken v. Bradley and Residential Segregation, October 22, 1974 (paper available from National Comm. Against Discrimination in Housing); Farley, Residential Segregation and Its Implications for School Integration, 39 LAw \& CoNTEMP. Prob. no. 1, at 164 (1975); Pettigrew, A Sociological View of the Post-Bradley Era, 21 WAste L. REv. 813 (1975); Taylor, supra note 351.

Professor Karl Taeuber, who testified as an expert witness in Milliken $v$. Bradley, has reviewed the causes of residential segregation in a recent article. Taeuber, Demographic Perspectives on Housing and School Segregation, 21 Warce L. Rev. 833, 836-41 (1975). He concludes the discussion by noting that "the prime cause of residential segregation by race has been discrimination, both public and private." Taeuber, supra at 840 . In the same issue, Professor Farley, after a review of the available data, reaches similar conclusions. Farley, Population Trends and School Segregation in the Detroit Metropolitan Area, 21 Wayne L. Rev. 867, 882-89 (1975). Professor Farley examines the question of the absence of blacks from the Detroit suburbs, and finds that "[o]pening the suburbs of Detroit to blacks is not a problem of opening them to low or middle income families; rather it is very specifically a question of opening them to blacks." Farley, supra at 884-85.

354. 510 F.2d 1358 (6th Cir. 1974), cert. denied, 95 S.Ct. 1658 (1975).

355. 489 F.2d 925 (6th Cir. 1973), vacated, 418 U.S. 918 (1974).

356. 418 U.S. 918 (1974).

357. 510 F.2d at 1361 .

358. Id. Note the culpability or "guili" language. See text accompanying note 342, at p. 105 supra. 
the same county of the state being equally guilty in failing to eliminate all vestiges of segregation . . . " ${ }^{358}$ Also, the cross-district effect was present: [S]chool district lines in Kentucky have been ignored in the past for the purpose of aiding and implementing continued segregation. Such disregarding of school district lines continues to have an effect on racial imbalance in the county's schools . . ." 359 Thus, on remand of the case to the district court, the circuit court noted that the desegregation order could, if needed, include an interdistrict remedy. ${ }^{360}$

A second decision since the Detroit case has also found sufficient distinguishing factors to permit an interdistrict remedy. In United States v. Missouri, ${ }^{361}$ the plaintiffs were seeking the annexation of two districts-one of which was all black-by a third district to create a new district out of the three. The district court found sufficient evidence to show that there was ${ }^{362}$

an arrangemen of school districts which has caused substantial segregation and which is both a vestige of the previously imposed dual school system and a continuing effect of racially discriminatory state actions on the part of the defendants in this case.

The other two districts were "responsible for the maintenance of [the all black district] as a segregated district." ${ }^{363}$ The court found the opposition of the electorate to reorganizing the districts in 1949 to be grounded in racial considerations. ${ }^{364}$

This is an inslance where the failure to act or resistance for discriminatory reasons to actions tending to correct segregation amounted to a constitutional wrong.

The final factor differentiating the Detroit case from the Missouri case was that in the latter, "only three districts, not fifty-two districts, are involved." $36 ;$

359. 510 F.2d at 1360. For example. for a considerable period. Jefferson County had no black high school and had sent its black students 10 a black high school in Louisville.

360. 510 F.2d at 1361 . The case was appealed to the Supreme Court once again. but the pet $j$ tion for certiorari was denied, 95 S.Ci. 1658 (1975). For district couris order see 8 Ed. Daily, Aug. 5, 1975, at 1 .

361. 388 F. Supp. 1058 (E.D. Mo. 1975)

362. 388 F. Supp. at 1059 .

363. 388 F. Supp. at 1060 .

364. Id.

365. Id. It is interesting to note that the district count in this case was more aware than most courts of the disproportionate burden that tends to fall on black students in any desegregation order. See text at pp. 88-90 supra.

The primary burden of desegregation under the Revised Plan unavoidably falls on black students because of the educational necessity, recognized by all the parties, of terminating the present use of three school facilities located in the Kinloch [all-black] School District. In order to minimize this burden as much as possible, the following steps shall be taken:

(1) Kinloch Elementary [formerly all-black] shall be assigned lower elementary grades instead of grades five and six.

(4) School authorities shall take steps to insure that black students transferred to formerly white schools are made to feel a part of such schools. To this end, considera- 
Finally, the Indianapolis case $\mathrm{s}^{366}$ also indicates that city-county consolidations may be easier to accomplish than the other two metropolitan arrangements previously discussed. The Seventh Circuit affirmed the district court's findings that state officials had "promoted segregation and inhibited desegregation" 367 within the Indianapolis School District, thus placing upon the state as well as the school district an affirmative duty to desegregate within the boundaries of Indianapolis. ${ }^{368}$

The district court had sought to impose a metropolitan area remedy-to include all of Marion County (the county in which Indianapolis is situated), as well as two school districts beyond the county line. Relying upon the Supreme Court's opinion in the Detroit case, the circuit court reversed the district court's opinion with regard to the areas beyond Marion County. ${ }^{369}$ The court did not reverse, but vacated and remanded for further findings, that part of the district court's remedy which included school districts within the county boundaries. ${ }^{370}$

There may well be unique circumstances in the Indianapolis case which could trigger a finding of deliberate segregative intent and effect on the part of the county as well as the city and thus support a city-county consolidation. In 1971, the Uni-Gov Act was passed which consolidated the governments of Indianapolis and Marion County into one metropolitan governmental unit. ${ }^{3 i 1}$ However, the Act specifically excepted from such consolidation "any [preexisting] school corporation, all or a part of which is in the consolidated city or county." 372 This meant that, in addition to Indianapolis, there were "eight township school systems operating independently within the purportedly unified City..." ${ }^{373}$ On remand, the circuit court asked the district court to determine whether "the establishment of the Uni-Gov boundaries without a like reestablishment of [the Indianapolis school district] boundaries warrants an inter-district remedy within Uni-Gov in accordance with Milliken." 374

There are still a few metropolitan area suits pending. At least two of these could be resolved by a city-county consolidation and thus appear to have a better chance of success than a Detroit-type of case. And in one of these

tion should be given to renaming such schools, changing school colors, etc., and the preservation of Kinloch High School trophies and awards. Non-discriminatory regulation and procedures shall be developed concerning disciplinary measures.

388 F. Supp. at 1061-62.

366. Lnited States v. Board of School Comm rs, 368 F. Supp. 1191 (S.D. Ind. 1973). aff'd in part and revid in part, 503 F.2d 68 (7th Cir. 1974), cert. denied, 95 S.Cr. 1655 (1975).

367.503 F.2d at 80 .

368. Id.

369. Id.

370. 503 F.2d at 86.

371. IND. Code 18-4-1-1 to 18-4-15-2 (1971).

372. IND. CODE 18-4-3-14 (1971).

373. United States v. Board of School Commirs, 332 F. Supp. 655, 676 (S.D. Ind. 1971), aff d, 477 F.2d 81 (71h Cir. 1972), cert. denied, 413 L'S. 920 (1973).

374. 503 F.2d at 86. The district court, then, ordered cross busing. 8 Ed. Dally, Aug. 7, 1975. at 1 . 
pending suits ${ }^{375}$-involving Wilmington, Delaware and its predominantly white suburban county-there is evidence that a state statute adopted in 1968, reorganizing and consolidating all school districts with the exception of the city of Wilmington, ${ }^{376}$ with its over 80 per cent black student enrollment, acted to "contain" minority students within the boundaries of the city. ${ }^{377}$ Another potential metropolitan-area suit is Armour v. Nix, ${ }^{378}$ involving Atlanta and its predominantly white suburban county. In one of its (many) Calhoun v. Cook decisions, the district court raised the question of consolidation of the Atlanta school system with the Fulton County system. ${ }^{379}$

In terms of efficiency, taxes, and quality education, such consolidations normally produce long-range im provements. In terms of the current problem such consolidation might well produce partial, even though not perfect, solutions. ...

The court of appeals, at various phases of the Calhoun case, has also expressed its interest in a consideration of a metropolitan solution. ${ }^{380}$

\section{Local Control: The Making of a Myth}

What considerations might militate against the granting of relief as drastic as desegregation across district lines even if interdistrict intentional segregative acts can be proved? Is the interest in "local control" of schools a relevant factor? In several recent cases, the Supreme Court has begun to acknowledge that local control or local autonomy in public education is a very substantial interest: first, in the school financing case-San Antonio Independent School District $\mho$. Rodriguez ${ }^{381}$ - and now in the Detroit case. ${ }^{382}$ In an earlier opinion, Justice Stewart, speaking for the Court, had said that "[d]irect control over decisions vitally affecting the education of one's children is a need that is strongly felt in our society... ${ }^{383}$ In his dissent in that same opinion, Chief Justice Burger agreed, stating that local control was of "overriding importance," ${ }^{384}$ and he continued this line of thought in his majority opinion in Milliken v. Bradley: ${ }^{385}$

375. Evans v. Buchanan, 379 F. Supp. 1218 (D. Del. 1974).

376. Ch. 292, §6, [1967] Del. Laws 979 .

377. After the Detroit decision was handed down, the three-judge district court in Delaware ruled that the statute was unconstitutional in its exclusion of the Wilmington school district. The court found the statute to be an "interdistrict violation" that "played a significant part in maintaining the racial identifiability of Wilmington and the suburban New Castle County school districts." $\div$. F. Supp (D. Del. Mar. 23, 1975). See discussion in Taylor, supra note 351, at $759-60$.

378. Armour v. Nix, Civil No. 16708 (N.D. Ga. June 7. 1972).

379. 332 F. Supp. 804,809 (N.D. Ga. 1971).

380. 451 F.2d 583 (5th Cir. 1971); 487 F.2d 680, 684 (5th Cir. 1973).

381. 411 U.S. 1, 49-50 (1973).

382. 418 U.S. $717,741-42$ (1974).

383. Wright v. Council of the City of Emporia, 407 U.S. 451,469 (1973).

384. Id. at 478 (emphasis added). "Local control is not only vital to continued public support of the schools, but is of overriding importance from an educational standpoint as well." This statement was subsequently quoted with approval by the majority in Rodriguez, 411 U.S. at 49.

385. 418 U.S. at 741-42 (emphasis added). 
Boundary lines may be bridged where there has been a constitutional violation calling for interdistrict relief, but the notion that school district lines may be casually ignored or treated as a mere administrative convenience is contrary to the history of public education in our country. No single tradition in public education is more deeply rooted than local control over the operation of schools; local autonomy has long been thought essential both to the maintenance of community concern and support for public schools and to quality of the educational process.

Perhaps the most outstanding feature of these repeated statements sanctifying local control is the dearth of authority cited by way of support.

In the Detroit case ${ }^{386}$ the Sixth Circuit devoted three and one-quarter pages to a review of the evidence of state control over education in Michigan: ${ }^{387}$

As held by the District Court, it is well established under the Constitution and laws of Michigan that the public school system is a State function and that local school districts are instrumentalities of the State created for administrative convenience.

The circuit court cited constitutional and statutory provisions and Michigan Supreme Court interpretations in support of this statement, ${ }^{388}$ and concluded that ${ }^{389}$

the record [has] establish[ed] that the State has committed de jure acts of segregation and. that the State controls the instrumentalities whose action is necessary to remedy the harmful effects of the State acts.

The Supreme Court ignored this treatment, stating only that Michigan, "in common with most States, provides for a large measure of local control," 390 and citing statutes giving the local school district the power to determine "the dayto-day affairs of the school district . . ."391 Justice Douglas vigorously dissented from this view: "[e]ducation in Michigan is a state project with very little completely local control .... [T] he school districts by state law are agencies of the State." 392

Michigan does provide a large measure of local control, yet it has been held repeatedly that a school district is merely a subordinate arm of the state agency.

386. Bradley v. Milliken, 484 F.2d 215, 245-49 (6th Cir. 1973). rev'd, 418 U.S. 717 (1974).

387. 484 F.2d at 246.

388. E.g., id., citing Child Welfare Soc'y v. Kennedy School Dist., 220 Mich. 290, 296, 189 N.W. 1002, 1004 (1922):

The Legislature has entire control over the schools of the state subject only to the provisions above referred to. The division of the territory of the state into districts, the conduct of the school, the qualifications of teachers, the subjects to be taught therein, are all within its control.

389. 484 F.2d al 249.

390. 418 U.S. 717,742 (1974).

391. Id. at 742 n. 20.

392. 418 U.S. at 758-59. See also id. at 770 (White, J., dissenting); id. at 786, 793-97 (Marshall, J.. dissenting). 
A school district has no inherent power, only power expressly delegated or necessarily implied. Under Michigan law, as is true of most states, ${ }^{393}$ the state legislature can consolidate, merge, or eliminate school districts at will, regardless of the local district's opposition to such moves. ${ }^{394}$

A recent study of ten states and the degree to which there was state control over local education decision-making in the areas of curricular requirements, budgetary and taxing restrictions, regulations affecting personnel, and district formation, dissolution, annexation and consolidation, showed that state statutes and regulations sharply limited the degree of local district autonomy in the majority of the ten states studied. ${ }^{395}$ Michigan was found to rank fifth in the degree of state-level controls on local district decision making; ${ }^{396}$ in the area of district formation and consolidation, however, Michigan was grouped with those states which have the strongest degree of state-level control. ${ }^{397}$ Such research casts significant doubt on the Court's developing theory of "local control" as a barrier to otherwise valid remedies for violations of the equal protection clause.

The Court's concern for preserving "local control," as with its concern regarding the administrative and financing (including the validity of long-term bonds) problems presented by consolidating 54 school districts, ${ }^{398}$ arguably

393. The standard education law textbooks indicate how much of this power is located in the state rather than in the local school district. See, e.g., E. Reutter \& R. Hamilton, The Law of Public Education 61, 108 (1970).

School districts are governmental agencies of the state created by the state as instrumentalities through which the legislature carries out the state constitutional mandate to provide for a system of public education. At any time the legislature may abolish all local school units and redistrict the state irrespective of the boundaries of the old districts. Unless the constitution of the state requires it, it is not necessary to procure the consent of the inhabitants of the territory as a condition to redistricting. Indeed, even though local inhabitants have voted against a boundary alteration, the legislature can still proceed to effect the consolidation of districts.

The powers of local boards, since they are granted by the legislature, may be changed at any time. ... When in doubt, the courts, under common law, are inclined to find against an implied power. There are no inherent powers in school boards.

This textbook uses a Michigan case, Attorney General ex rel. Kies v. Lowrey, 199 U.S. 233 (1905), to illustrate the subchapter entitled "Power of State Legislature to Change District Boundaries." E. Reutter \& R. Hamilton, supra at 86.

See also M. Sorgen, P. Duffy, W. Kaplin, \& E. Margolin, State, School, and Family ch. 2, at $10(1973)$.

394. "[T] he State has wide-ranging powers to consolidate and merge school districts, even without the consent of the districts themselves or of the local citizenry." 418 U.S. at 796 (Marshall, $\mathrm{J}$., dissenting). As Justice Marshall points out, $i d$., there has been a substantial effort in the sixties -largely initiated at the state level-to consolidate, annex, and merge school districts. Between 1964 and 1972, the number of school districts dropped from 1,438 to 608. Some of these mergers were state-mandated; others were stimulated by fiscal incentives provided by the state legislature. See Mich. Comp. Laws Ans. $\S 8340.401-.415,340.431-.449$ (1967).

395. B. Levin \& M. Cohen, Levels of State Aid Related to State Restrictions on local School District Decision-Making (1973).

396. Id. at 18 , Table 3 .

397. Id. at 17, Table 2.

398. 418 U.S. at 743 . 
would not be relevant had the Court determined that there was an interdistrict violation of the fourteenth amendment. The majority notes that ${ }^{399}$

School district lines and the present laws with respect to local control are not sacrosanct and if they conflict with the Fourteenth Amendment federal courts have a duty to prescribe appropriate remedies.

This suggests, again, that the Court has entangled questions of remedy with questions of constitutional violation.

\section{E. Special Remedies in Cases Involving Hispano-Americans}

School desegregation law, as it has developed, in large measure has benefitted Hispano-Americans. Having evolved in the context of the segregation of blacks in the states of the deep South, however, it is not always completely transferable from one group of litigants to the other. School desegregation litigation, by and large, seeks to win for black pupils the right to be treated as others are. For many Hispano-Americans, this seems to be too narrow a focus and a potentially self-defeating objective in view of the desire to retain their language and culture. Does the legal system have the capacity to explore alternatives and broaden the range of issues? And in so doing, what social science evidence can aid in such an endeavor?

Clearly much of the relief sought by the two minority groups is the same. As do blacks, Hispano-Americans seek desegregation of school faculties, staffs, and student populations. And as do blacks, Hispano-Americans seek to challenge the disproportionate assignment of Hispano-American students to classes for the Educable Mentally Retarded (EMR), and their over-representation in "low ability" classes in elementary schools and in noncollege-bound tracks in junior and senior high schools. ${ }^{400}$

But Hispano-Americans also seek special programs-not generally sought by black litigants - which are designed to enhance the educational process. Since much of the learning deficiencies found in Hispano children are attributable to language and culture differences, questions of remedy therefore include-but by no means are limited to-whether and when bilingualbicultural education can be required.

The difficulty of devising remedies to meet the demands of litigants with somewhat differing needs is most apparent in tri-ethnic school districts. This

399. 418 U.S. at 744 .

[W]hatever difficulties [in managing a desegregation plan which includes suburban districts] there might be, they are surmountable; for the Court itself concedes that had there been sufficient evidence of an interdistrict violation, the District Court could have fashioned a single remedy for the districts implicated rather than a different remedy for each district in which the violation had occurred or had an impact.

418 U.S. at $769-70$ (White, J., dissenting).

400. Ability grouping and the assignment to classes for the educable mentally retarded (EMR) are discussed in the text at pp. 120-29 infra. 
problem was dealt with in the Denver case-where the student enrollment in the elementary schools in the fall of 1973 was 17.6 per cent black, 27 per cent Spanish surnamed, and 54.1 per cent Anglo ${ }^{401}$-by adopting a separate remedial plan for Mexican-American students. Following the Supreme Court's remand, ${ }^{402}$ the district court heard testimony on various proposed desegregation plans. The Congress of Hispanic Educators, which intervened in the suit, put forward a separate remedial plan which would establish a bilingualbicultural educational program for Hispano-Americans. The plan was prepared by an educator, Dr. Jose Cárdenas, and was said to be designed to resolve the incompatibilities faced by Spanish-speaking school children who are "expected not only to learn a language with which they are unfamiliar, but also to acquire normal basic learning skills which are taught through the medium of that unfamiliar language. ${ }^{{ }^{403}}$ Such a program, it was argued, should include: ${ }^{404}$

(1) development of the child's knowledge of English,

(2) instruction in any substantive subject in the child's native language,

(3) promulgation of minimum educational standards,

(4) distribution of appropriate materials,

(5) recruitment of bilingual educators, and

(6) establishment of pilot schools.

As the district court viewed the Cárdenas plan, it ${ }^{405}$

recommend[ed] adjustments in the Denver educational system . . which ... will make that system more compatible to the minority child's economic circumstances, his cultural and language orientation, his high degree of mobility, and his perceptions of himself and the world around him. Dr. Cárdenas plan is at heart based on the conviction that minority youngsters often fail or perform poorly in the typical American school system today, because the school the child attends, whether integrated or segregated, is largely an alien world to him, where classes, including the most basic of skills, are taught in a language which the child often does not comprehend or lacks facility in, where he is asked to relate to experiences which have no relevance to him outside the schools, and where he is often taught to regard negatively his own background, culture and personal abilities.

The court found ${ }^{406}$

the Cárdenas or bilingual-bicultural approach to the education of [Mexican-Americans to be] a very sensible method and to the extent that it can be useful to building bridges between the Spanish and Anglo cultures, it is to be fully utilized.

A number of other courts have also considered bilingual-bicultural approaches as part of the relief in desegregation cases involving Hispano-

401. Keyes v. School Dist. No. I, 380 F. Supp. 673, 674 (D. Colo. 1974).

402. 413 U.S. $189(1973)$.

403. $380 \mathrm{~F}$. Supp. at 695 .

404. Brief for Congress of Hispanic Educators as Plaintiff-Intervenor, Keyes v. School Dist. No.

1. Civil Nos. 74-1349 to 50 (10th Cir. June 25, 1974).

405. 380 F. Supp. at 694-95.

406. 380 F. Supp. at 692 . 
Americans. In United States v. Texas Education Agency, ${ }^{407}$ the district court, having concluded that bilingual education was the only means of achieving "true integration as opposed to mere desegregation," 408 ordered a comprehensive bilingual and bicultural educational program to be instituted, covering not only standard classroom instruction, but also professional staff treatment, assignment, and development; student assignment and classroom organization; parent and community involvement; special education; and extra-curricular activities. $^{409}$

In Serna v. Portales Municipal Schools, ${ }^{410}$ the predominantly Hispano school in that district was already operating a bilingual-bicultural program; however, such a program was not available at the other elementary schools in the district even though these schools were attended by a number of Hispano children. The district court required the establishment of a bilingual-bicultural program at all elementary schools in the district as well as the hiring of more Spanishspeaking teachers. ${ }^{411}$ The Tenth Circuit ${ }^{412}$ followed Lau v. Nichols ${ }^{413}$ in finding a statutory violation of the students' Title VI rights rather than a constitutional violation, ${ }^{414}$ but the result was the same. In discussing the question of relief, the circuit court stated: ${ }^{45}$

The evidence shows unequirocally that appellants had failed to provide appellees with a meaningful education. . . [T] [Te trial court had a duty to fashion a program which would provide adequate relief for Spanish surnamed children. ... Under Title VI of the Civil Rights Act of 1964 appellees have a right to bilingual education. . . . [T] he trial court under its inherent equitable power, can properly fashion a bilingual-bicultural program which will assure that Spanish surnamed children receive a meaningful education.

The court thus indicated that under certain circumstances it is not an unwarranted intrusion for the federal district court, using its equitable powers, to choose among educational programs.

Another illustration of a situation in which a mechanical application to Hispano-Americans of desegregation law developed in the context of southern blacks is inappropriate is that of assignment of minority teachers. Under the

\footnotetext{
407. 342 F. Supp. 24 (E.D. Tex. 1971), revid on other grounds, 467 F.2d 848 (5th Cir. 1972).

408. Id. at 28 .

409. Id. at 29-38. In reversing the district court, the Fifth Circuit, while "congratulating" the school district's plan for its bilingual programs. cautioned that "[t]hese techniques . . may not be used as a substitute for adequate desegregation." 467 F.2d 848, 873 (5̆th Cir. 1972). See also Arvizu v. Waco Independent School Dist., 373 F. Supp. 1264 (W.D. Tex. 1973), aff'd in part, rev'd as to other issues, 495 F.2d 499 (5th Cir. 1974). There the court ordered a bilingual-bicultural program to be developed with the assistance of "available Mexican-American educational consultants." Id. at 1280. Cf. Aspirav. Board of Educ, Consent Decree (S.D.N.Y. Aug. 29, 1974).

410. 351 F. Supp. 1279 (D.N.M. 1971), aff'd on other grounds, 499 F.2d 1147 (10th Cir. 1974).

411. Id. at $1282-83$.

412. 499 F.2d 1147 (10th Cir, 1974).

413. 414 U.S. 563 (1974).

414. 499 F.2d at $1152-53$.

415.499 F.2d at 1154 .
} 
principle of the Singleton ratio, ${ }^{416}$ minority teachers are to be distributed throughout the system so that the staff of each school reflects the proportion of minority teachers in the system as a whole. The difficulty with applying this to Hispano-American teachers is that, compared to blacks, there are relatively few trained in teaching. Thus assigning minority teachers so that there is an even distribution throughout a given school district is an inadequate remedy as far as Hispano-American desegregation law suits are concerned. Judge Wisdom, in United States $v$. Texas Education Agency, ${ }^{417}$ recognizing this, concluded that the school district should strive for parity hiring rather than distribution of an unrepresentative number of Mexican-American teachers throughout the school district. ${ }^{418}$

In the Denver case, the district court judge also rejected the Singleton ratio as an appropriate desegregation remedy for Mexican-Americans due to the fact that while Mexican-Americans comprised 26 per cent of the elementary school population they comprised less than 4 per cent of the teaching staff. ${ }^{419}$ The district judge extended Judge Wisdom's logic to require the immediate implementation of an affirmative action plan with goals and a timetable for hiring minority teachers. ${ }^{400}$ And the Serna court went even further, adding that a good faith effort to recruit Spanish-speaking teachers would not be enough if that effort were unsuccessful. ${ }^{421}$

Substantial numbers of Hispano-American students are excluded from effective participation in the educational process because of language and cultural characteristics. In a study of school districts in the Southwest, undertaken by the United States Commission on Civil Rights, 16 per cent of the MexicanAmerican students repeated the first grade while only 6 per cent of the Anglo

\footnotetext{
416. Faculty and staff are to be assigned to schools

so that the ratio of Negro to white teachers in each school, and the ratio of other staff in each, are substantially the same as each such ratio is to the teachers and other staff, respectively, in the entire school system.
}

Singleton v. Jackson Municipal Separate School Dist., 419 F.2d 1211,1218 (5th Cir.), revid on other grounds per curam sub nom. Carter v. West Feliciana School Bd., 396 U.S. 290 (1970). See also United States v. Montgomery County Bd. of Educ., 395 U.S. 225, 235-36 (1969).

417. 467 F.2d 848 (5th Cir. 1972)

418. Rigid adherence to... [the Singleton ratio] principle would be inequitable in this case . . . since there are so few Mexican-American teachers, 3 percent of the total faculty as against a Mexican-American school population of 20 percent.

When the figures speak so eloquently, a prima facie case of discrimination is established. .. The school board therefore should attempt to employ more Mexican-American teachers with the goal of attaining a ratio of Mexican-American teachers within the faculty that reflects more truly the ratio of Mexican-American students to the total population. A showing of a good faith effort to find sufficient qualified Mexican-American teachers to achieve an equitable ratio, will rebut any inference of discrimination. . . Id. at 873. See also Cisneros v. Corpus Christi Independent School Dist., 467 F.2d 142, 152 (5th Cir. 1972), cert. denied, 413 U.S. 920 (1973).

419. Keyes v. School Dist. No. 1, 380 F. Supp. 673, at 674, 680, 688 (D. Colo. 1974).

420. 380 F. Supp. at 688.

421. 351 F. Supp. 1279, 1283, aff'd on other grounds, 499 F.2d 1147 (10th Cir. 1974). 
students and 8.9 per cent of the black students had to repeat this grade. ${ }^{422}$ In Texas, 80 per cent of the Mexican-American children who enter the first grade are not promoted. ${ }^{423}$

Until recently, many states added impediments to the child's ability to learn rather than facilitating their removal. The language barrier was looked upon as the child's burden which he had to overcome, rather than as the school's responsibility. ${ }^{424}$ Most states no longer have laws prohibiting foreign languages from being used in schools. ${ }^{425}$ Nevertheless a substantial number of school districts in the Southwest still have an official written policy of prohibiting the use of Spanish either on the school grounds or in the classroom. And there is some evidence that children are still subject to corporal punishment, to daily fines, or to suspension and expulsion for using Spanish in violation of this policy. ${ }^{426}$ Until recently, Texas made it a crime for a teacher to speak Spanish in the course of ordinary school activities. ${ }^{427}$ As late as 1970, a MexicanAmerican teacher in that state was indicted for conducting a high school history class in Spanish, although the case was subsequently dismissed. ${ }^{428}$ One state still provides criminal penalties for violation of the requirement that English be the exclusive language of instruction. ${ }^{429}$

Today, however, many states have adopted laws permitting bilingual instruction, ${ }^{\mathbf{4 3 0}}$ and two states have laws requiring bilingual instruction where there are a certain number of students whose native tongue is not English. ${ }^{431}$ And, as previously noted, there are now a number of judicial decisions in which

422. U.S. Commission on Civil Rights, Mexican American Education Study, Report Il: Toward Quality Education for Mexican Americans 35 (1971).

423. T. Anderson \& M. Boyer, Bilingual Schooling in the United States 108 (1970).

424. Cf. note 139 and accompanying text at p. 74 supra.

425. However, eight states still require English as the exclusive language of instruction in schools. Ark. STAt. ANx. \$ 80-1605 (1960); IdAho Code \$ 33-1601 (1963); Ky. Rev. Stat. Axi. \$ 158.080 (Supp. 1972); Minn. Stat. Ann. \$ 126.07 (1960); Mont. Rev. Codes ANw. $\$ 75-7503$ to 7504 (1971); Neb. Const. art. 1, § 27; Okla. Const. art. 1, §5; Okla. Stat. tit. 70, §11-102 (Supp. 1972); Wis. Stat. Ann. $\$ 40.46(1)$ (1966).

426. U.S. Comission on Civil Rights, Mexican American Education Study. Report Ill: Toward Quality Education for Mexican Americans (1971).

427. See Ch. 80, [1918] Tex. Gen. Laws, 4th Called Sess. 170 (repealed 1971); text at note 161 supra.

428. U.S. Commission on Civil Rights, supra note 426, at 15.

429. ARk. Stat. Ann. \$ 80-1605 (1960). Three other states only very recently amended similar laws with criminal penalties. Ch. 166, [1923] Conn. Pub. Acts. 3591, as amended Conn. Gen. Stat. ANN. $\$ 10.17$ (Supp. 1975); ch. 198, [1919] Iowa Acts 219, as amended ch. 1168, \$6, [1974] lowa Acts 540; ch. 138, §§ 265-66, [1931] S.D. Laws 175-76, as amended S.D. Compiled Laws AxN. 13-33-11 (Supp. 1974).

430. E.g., Ariz. Rev. Stat. Ann. $\$ 15-202,15-1097$ to 1099 (Supp. 1974); Cal. Educ. Code $\S$ 71, 5766-69, 6457, 13273.5 (West 1975); Colo. Rev. Stat. Ans. § 22-1-103 (1973); Conn. Gen. Stat. AnN. $\$ 10.17$ (Supp. 1975); lll. Rev. Stat. ch. 122 \$ 10-22.28a. 34-18.2 (Supp. 1975): Kan. STAt. ANn. \$62-1101 (1972); ME. Rev. Stat. ANN. tit. 20, \& 102(16) (Supp. 1974); N.M. Stat. ANN. $\S \S 77-23-1$ to 7 (Supp. 1973); N.Y. Educ. LaW $\$ 3204(2 a)$ (McKinney 1970); Ore. Rev. STAT, $\S$ 336.074-.079 (1973); Pa. Stat. Anw. tit. 24, \$15-15ll (Supp. 1974); Tex. Educ. Code Ann. \& $11.11(1972)$.

431. Alaska Stat. $\$ 14.08 .160$ (Cum. Supp. 1974); Mass. Gen. Laws Ann. ch. 71 A (Supp. 1974). 
bilingual education has been found to be at least a statutory $y^{432}$ if not a constitutional right. ${ }^{433}$

Many school districts currently offer Spanish speaking students either segregated bilingual education or integration without bilingual education. ${ }^{434}$ Neither of these "Hobson's Choice" alternatives are acceptable to many Hispano-Americans. The district court in United States $v$. Texas recognized the problem of seemingly conflicting objectives: ${ }^{435}$

[There is] . . the need . . f for special educational consideration to be given to the Mexican-American students in assisting them in adjusting to those parts of their new school environment which present a cultural and linguistic shock. Equally clear, however, is the need to avoid the creation of a stigma of inferiority akin to the "badges and indicia of slavery" . . . To avoid this result the Anglo-American students too must be called upon to adjust to their MexicanAmerican classmates, and to learn to understand and appreciate their different linguistic and cultural attributes.

In the Denver case, however, the district court recognized a desire not to be desegregated if that meant giving up bilingual education. ${ }^{436}$ In one of the schools, a pilot bilingual-bicultural program was already underway. The court noted that some "representatives of the Mexican-American community" 437 asked that the school not be desegregated during the period the program was developing. The court therefore held that "desegregation is not in its best interests." 438

Theoretically, bilingual-bicultural education and integration are not incompatible. Federal regulations under the Bilingual Education Act require school districts to make good faith efforts to integrate their federally funded bilingual programs. ${ }^{49}$ By and large, however, they are neither integrated nor truly

432. Serna v. Portales Municipal Schools, 499 F.2d 1147, 1153-54 (10th Cir. 1974); Lau v. Nichols, 414 U.S. 563, 566-69 (1974).

433. For legal arguments on behalf of a constitutional right to bilingual education, see Note, The Constitutional Right of Bilingual Children to an Equal Educational Opportunity, 47 S. CALif. L. REv. 943 (1974).

434. Cárdenas, Bilingual Education, Segregation, and a Third Alternative, 1975 Inequality IN ED. no. 19 , at 20 .

435. 342 F. Supp. 24, 28 (E.D. Tex. 1971), aff'd, 466 F.2d 518 (5th Cir. 1972). The court, therefore, ordered the creation of a unitary school system in which "neither English nor Spanish is presented as a more valued language ...."Id. at 30. The court also ordered the implementation of a "bilingual-bicultural instructional program which utilizes the child's language system (English, Spanish, or a blend of both) as the medium of insuruction as proficiency in one or more additional language systems is developed." Id. at 31 .

436. Keyes v. School Dist. No. 1, 380 F. Supp. 673, 692 (D. Colo. 1974).

437. Id.

438. Id.

439. 20 U.S.C.A. $\$ 880$ b et seq. (1975).

A program assisted under this Part shall include such provisions as are necessary to prevent the separation of children by language or ethnic background in any activity included in such programs, unless the applicant demonstrates that such separation for a portion of the school day for specific language learning activities is essential to the achievement of the purpose of this part.

40 Fed. Reg. 26517-18 (1975) (emphasis added). 
bilingual; rather, the English as a Second Language (ESL) program is what is usually provided. Such programs rely exclusively on the use of the English language; the child is compelled to learn a new language and at the same time to learn course material in the new language. Thus Hispano-American children, not surprisingly, fall behind Anglo children in such substantive curricular areas as math, geography, history, etc.

The principal use of social science in cases involving Hispano students has been through the introduction of expert witnesses-educators or psychologists-who portray the incompatibility between the characteristics of the non-Anglo-Saxon child and the characteristics of the white, middle class educational program being offered. Studies have also been cited which show that large numbers of Hispano students-through the use of $1 Q$ or other standardized intelligence and achievement tests that tend to measure the students' ability to read and understand English rather than their actual intelligence -have been improperly assigned to classes for the educable mentally retarded (EMR) or low track or ability groupings. ${ }^{40}$

In sum, that Hispano-Americans may require, as part of any desegregation decree, special remedies not sought by black litigants is a principle gradually being developed by the courts. Coupled with this is the growing recognition of, at the least, a statutory right to bilingual education and of the inappropriateness of using tests based on English language skills to determine a child's placement in special classes or tracks.

\section{IV}

\section{Second Generation Problems}

A school system may in some respects remain segregated even after a court-ordered desegregation plan has been fully implemented. Through various practices such as ability grouping and the selective use of disciplinary measures, minority children may continue to receive different and apparently unequal treatment. These practices may bring about resegregation of the school system in frustration of the court-ordered plan. Do these practices, even when they are educationally valid and racially neutral, violate the fourteenth amendment? If so, to what extent may inexpert judges intervene in the educational process to fashion an appropriate remedy to protect the rights and interests of minority children? And when the courts do intervene, what social science evidence may they turn to for guidance?

\section{A. Tracking and Ability Grouping}

One of the most frequently used practices responsible for bringing about resegregation is the use of tracking or ability grouping following the adoption of a desegregation plan. The courts have been fairly consistent in holding that

440. These cases are discussed in the text at pp. 126-27 infra. 
when a formerly dual, segregated school system is in the process of being or has just recently been dismantled, pupil assignment by standardized achievement or IQ test scores is prohibited when the intended and actual result is the perpetuation of the dual system. This is so whether the continuing segregation exists within the system as a whole, ${ }^{441}$ within individual schools, ${ }^{442}$ or even within individual classrooms. ${ }^{443}$
Ability groupings or the so-called "track method" may have academic justifica- tion and may be an educational rather than a constitutional issue, but the track system or "ability grouping" is suspect when it first begins to flourish on the eve of or during a desegregation suit. ${ }^{44}$

Apart from the blatant, racially-motivated misuse of such measures, is racially-neutral ability grouping a valid educational practice? It has been argued, in behalf of ability grouping, that the teacher can adjust his or her teaching methods and materials and reach most, if not all, of the students in a given classroom. In a heterogeneous classroom, on the other hand, the teacher would have to aim for the average range of ability, and thus would lose both those students significantly below and those above the average, as the material would either be too difficult or insufficiently challenging. Where the class has a narrower range of ability, the teacher should have more time for individualized, personal instruction.

In addition to improved student achievement, it has been argued that ability grouping promotes self-esteem. The child who does not have to compete with children who are significantly brighter or duller than he, can develop a healthy self-image as he works with children at his own level. ${ }^{445}$

While there is substantial social science research on these issues, the research is so contradictory that it cannot be said with any sense of conviction whether ability grouping does or does not lead to increased achievement and improved self-esteem in children. ${ }^{446}$ Some have termed ability grouping a sys-

441. See, e.g. Lemon v. Bossier Parish School Bd., 444 F.2d 1400 (5th Cir. 1971); United States v. Sunflower County School Dist., 430 F.2d 839, 841 (5th Cir.), cert. denied, 398 U.S. 951 (1970); Singleton v. Jackson Municipal Separate School Dist., 419 F.2d 1211,1219 (5th Cir. 1969), rev'd and remanded in part on other grounds sub nom. Carter v. West Feliciana Parish School Bd., 396 U.S. 290 (1970).

442. See, e.g., Moses v. Washington Parish School Bd., 456 F.2d 1285 (5th Cir.), cert. denied, 409 U.S. $1013(1972)$.

443. See, e.g. Acree v. County Bd. of Educ, 458 F.2d 486, 488 n. 3 (5th Cir.), cerl. denied, 409 U.S. 1006 (1972).

444. Singleton v. Anson County Bd. of Educ., Civil No. 2259 (W.D.N.C. July 3, 1967).

445. Goldberg \& Passow, The Effects of Ability Grouping in the Elementary Schools, in GroupiNG iN The Elementary Schools 22-23 (A. Morgenstern ed. 1966). The arguments that have been made, both for and against ability grouping, are summarized in National Education Association, Ability Grouping 8-10 (Research Summary No. 53, 1968).

446. See, e.g., Esposito, Homogeneous and Heterogeneous Ability Grouping: Principal Findings and Implications for Evaluating and Designing More Effective Educational Environments, 43 REv. ED. RES. 163, 167-68 (1973); Goodlad, Classroom Organization, in Encyclopedia of Educational Research 221 (C. Harris ed. 1960); Passow, The Maze of Research on Ability Grouping, 26 ED. Forum 281 (1962).

A brief review of two relatively large-scale studies illustrates the differing results obtainable: 
tem of "maximizing stigma and minimizing exposure." 447 Even if social science research more clearly indicated that ability grouping is a valid educational practice, is its continued use constitutionally permissible when the result, in a system otherwise adjudged to be unitary, is a clear separation of the races? ${ }^{\mathbf{4 4 8}}$ Does Brown require racial balance in spite of educationally valid reasons for separation? May segregative intent be inferred from tracking and ability group-

The first of these studies was begun in 1956 in New York City: approximately 3.000 fifth grade students were separated into five ability levels on the basis of $1 Q$ tests. The children were followed through the end of the sixth grade. The researchers reported that the effects of ability grouping on academic achievement were minimal at best. Goldberg \& Passow, supra note 445, at 31 . In fact, in not a single instance could the size of a child"s "achievement increment" be attributed to his status at the beginning of the school year. $I d$. ai 33 . Student achievement was correlated, not with a child's previously measured achievement, but with whether or not the particular teacher was interested in the particular subject being taught, regardless of the range of student ability in that subject. Moreover, the greatest academic gains for all students were attained in classrooms with the broadest range of abilities. $I d$. at 31-39. The more heterogeneous the classroom, the more all the children learned; and what they learned best was what the teacher liked best and consequently taught best.

Goldberg and Passow also found that teachers did not adjust their teaching methods and materials to the level of their students in homogeneous classes. The only adjustments that were ever made were in the lower ability classrooms, where teachers taught less of certain subjects than in the classrooms where brighter children were also present. Id. at 32 . The result was that the children in the lower ability homogeneous classes learned less than pupils of comparable ability who were placed in heterogeneous classes, especially in the areas of science and vocabulary. Thus "slower" children made greater academic gains when they were placed in heterogeneous classrooms and were exposed to the teaching aimed at the brighter children. $I d$. at 35 .

Of the three non-academic variables studied (self-attitude, social perceptions, and interest of pupils), only self-attitudes were sensitive to ability grouping. Id. at 34 . Ability grouping raised the self-image of the slower children (who were no longer forced to compete with the brightest children) and lowered the high self-ratings of the brightest children (who no longer stood out academically).

The second large-scale study-of 4,000 students in two homogeneous socioeconomic school districts in Utah-conducted in the mid-1960's, reached somewhat different conclusions. W. BorG, Ability Groupivg in the Public Schools: A Field Studi (1966). The superior students achieved greater academic gains when grouped homogeneously, although their study skills improved in the heterogeneous environment. There were some similarities with the New York study, however: the self-concept of the academic high achievers declined as a result of placement in homogeneous classes. For the slow students, achievement increased significantly and consistently when the students were in heterogeneous groups. Again as in the New York study, these students showed a gain in self-concept and self-esteem when grouped homogeneously. $I d$. at 91

447. M. McClung, Ability Grouping: The Practice of Maximizing Stigma and Minimizing Exposure in Public Schools, April 19, 1972 (mimeo on file at Harvard Center for Law \& Education).

448. The courts have thus far not reached this question. See, e.g. Singleton v. Jackson Municipal Separate School Dist., 419 F.2d 1211 (5th Cir. 1970). "We pretermit a discussion of the validity per se of a [tracking or ability grouping] plan based on testing except to hold that testing cannot be employed in any event until unitary [i.e. desegregated] school systems have been established." $I d$. at 1219. Lemon v. Bossier Parish School Bd., 444 F.2d 1400 (5th C.ir. 1971). "We decline once again . . the invitation to rule on the validity of testing [to determine ability groupings] per se." Id. at 1401

Hobson v. Hansen, 269 F. Supp. 401 (D.D.C. 1967), aff d sub nom. Smuck v. Hobson, 408 F.2d 175 (D.C. Cir. 1969) comes closest to finding the use of tracking a constitutional violation per se.

The best and by far the most comprehensive discussion of tracking and ability grouping-covering the social science research and methodology as well as current legal doctrine-is Kirp, Schools a.s Sorters: The Constitutional and Policy Implications of Student Classification, 121 U. PA. L. REv. 705 (1973). 
ing practices which result in segregation in all or part of a school system? Who should bear the evidentiary burden? Might such practices which result in segregation require state authorities to bear the burden of showing that such actions are not racially motivated? ${ }^{49}$ Should plaintiffs be required to show that there are educationally feasible alternatives to ability grouping? Or should the burden be shifted to the school authorities to show that there is no other way of educating children effectively?

In Hobson $v$. Hansen ${ }^{450}$ the court held that a system of tracking which places minority students in lower levels of standard curricula is unconstitutional when it inhibits movement between tracks, thereby rendering the initial assignment to a lower track a permanent assignment. In theory, the track system was established to enable the school system to provide compensatory and remedial education for students in the lowest tracks in order to help those students move into higher tracks. In practice, however, such education was woefully lacking. ${ }^{451}$ When coupled with the court's discussion of the serious harm caused by segregation, however it is brought about, ${ }^{452}$ these findings suggest that the Hobson court might have abolished the tracking system even without the showing that the classifying tests were biased. ${ }^{453}$ The court did not reach this precise issue, however, leaving it open for future litigation.

On appeal, the circuit court expressly refused to "plunge into a sea of . . . difficult issues of educational policy" such as the appropriate balance between the "practical need" to group students by ability and the need to ensure equal educational opportunity to every student; the extent to which verbal skills tests can be used without adversely affecting the minority student's educational advancement, and the extent to which verbal tests must be adjusted to reflect available indicators of ability not dependent on verbal skills. ${ }^{454}$ The circuit court, therefore, interpreted Judge Wright's decree as abolishing the particular tracking system in existence in the District of Columbia school system at the time of the trial rather than abolishing all forms of ability grouping or tracking in the future. ${ }^{455}$

Attorneys in student classification cases face a number of practical difficulties: what patterns should they look for in order to determine whether grouping, tracking, streaming, or some form of instructional separation is being practiced; what are the weaknesses of each program; what are the available alternative teaching methods-with less of a segregative effect-which can readily be adapted to a particular school district? The sharp and unresolved

449. Cf. Keyes v. School Dist. No. 1, 413 U.S. 189, 209-10 (1973); Swann v. CharlotteMecklenburg Bd. of Educ.. 402 U.S. I, 18, 26 (1971).

450. 269 F. Supp. 40 l (D.D.C. 1967), aff'd sub nom. Smuck v. Hobson, 408 F.2d 175 (D.C. Cir. $1969)$.

451. 269 F. Supp. at $469-70$

452. 269 F. Supp. at 503-06.

453. See discussion at notes $431 \& 432$ supra and accompanying text.

454. 408 F.2d at 188 .

455. 408 F.2d at 189-90. 
controversy over heterogeneous versus homogeneous grouping makes it difficult if not impossible for courts to adjudicate issues surrounding the use of these practices; moreover, given the present state of the art, the feasibility of educational alternatives cannot even be shown. ${ }^{456}$

\section{B. Use of Tests}

When ability grouping or tracking is practiced, the decisions as to which children are to be placed in which track are usually based on IQ or standardized achievement test scores, sometimes accompanied by the recommendations of teachers. Several law suits have challenged the tests themselves as being culturally biased, claiming that such tests lead to the misclassification of minority students. The use of untrained school officials in interpreting the tests has also been challenged. ${ }^{457}$

In Hobson $v$. Hansen, ${ }^{458}$ the court abolished the tracking system used in the public schools of the District of Columbia which assigned students to a particular curriculum track on the basis of standardized ability test scores. Relying on extensive social science evidence regarding the testing of disadvantaged children, ${ }^{459}$ the court found that the tests used were biased against black and other low-income students: ${ }^{460}$

When standard aptitude tests are given to low income Negro children, or disadvantaged children, . . . the tests are less precise and less accurate-so much so that test scores become practically meaningless. Because of the impoverished circumstances that characterize the disadvantaged child, it is virtually impossible to tell whether the test score reflects lack of ability-or simply lack of opportunity. Moreover, the probability that test scores of the Negro child or the disadvantaged child will be depressed because of somewhat unique psychological influences further compounds the risk of inaccuracy.

456. See Orfield, supra note 64, at 327-28.

457. In Stewart v. Phillips, Civil No. 70-1199-F (D. Mass. Feb. 8, 1971), plaintiffs (black and poor students placed in special classes) asserted that the tests are "biased-standardized to a white, middle class norm" and that the single score "fail[s] to distinguish among a wide range of learning disabilities-emotional, perceptual, linguistic, and cultural." CeNTER for LAW and Education, Classification Materials 283 (rev. ed. 1973) [hereinafter cited as Classification Materials]. Plaintiffs also claimed that "[m]any of the school psychologists administering and interpreting the tests are ... unqualified." $I$ d.

458. 269 F. Supp. 401 (D.D.C. 1967), aff'd sub nom. Smuck v. Hobson, 408 F.2d 175 (D.C. Cir. $1969)$.

459. 269 F. Supp. at 479-88. In support, Judge Wright cited the Lorton Study, N. BLrke \& A. Simons, A Measure of the Educational Achievement of a Group of InCarcerated Culturally Disadvantaged and Educationally Deprived Dropouts (1965), in which results of one of the standard verbal $I Q$ tests were compared to the results of a non-verbal $1 Q$ test. The results from the latter test were, on average, 29 points higher. $269 \mathrm{~F}$. Supp. at $485-87$ \& n. 136. The judge also cited, without discussion, a number of other social science writings on testing disadvantaged children, such as american Council on Education, Testing Problems in Perspective (A. Anastasi ed. 1967); K. Eels, Intelligence and Cultural Differences (1951); F. Riessman, The Culturally Deprived Child (1962); P. Sexton, Education and Income (1961); Deutsch \& Brown, Social Influences in Negro-White Intelligence Differences, $20 \mathrm{~J}$. Social Issues 24 (1964); and D. Goslin, Criticism of Standardized Tests and Testing (1967). 269 F. Supp. at 479-80 n. 130. 460. 269 F. Supp. at 485. 
One difficulty with the Hobson decision is that by abolishing the use of standardized tests without suggesting guidelines for procedures which would be constitutional, the court has left the school system without anything to fall back on. ${ }^{461}$ There is some doubt as to whether "culture-free" tests can be developed which would fill the gap. ${ }^{462}$

Although the district court in Hobson concluded that there had been de jure segregative practices on the part of the school authorities, ${ }^{463}$ it blurred the distinction between de jure and de facto segregation, ${ }^{464}$ suggesting that the Hobson case might be applicable to tracking situations where there has been no showing of de jure segregation.

A number of recent cases have challenged the use of tests to assign minority students to classes for the educable mentally retarded (EMR). The plaintiffs in such suits have alleged that the use of culturally biased tests has resulted in the misassignment of "normal" students to EMR classes. ${ }^{465}$ In one recent misclassification case, the use of $I Q$ tests was successfully attacked even though not even inferred segregative intent was shown. In Larry $P$. v. Riles, ${ }^{466}$ a federal district court enjoined the San Francisco Unified School District from assigning black students to classes for the educable mentally retarded (EMR) on the basis of IQ tests, when the result was a disproportionate number of black students in such classes. ${ }^{467}$ Plaintiffs were required to show (1) that a significant racial imbalance existed in the EMR classes, and (2) that the primary determinant of the assignment to an EMR class was the child's IQ test score. After these two things were shown, the burden of proof shifted to defendants to justify the use of the IQ tests. The defendants did not dispute the plaintiffs' evidence that the tests were culturally biased (e.g., when black psychologists administered the same IQ test with slight modifications to take into account the students' cultural background, the test scores were significantly higher). They merely argued that the tests were not the cause of the racial imbalance in the EMR classes, or, in the alternative, the tests, although racially biased, were rationally related to a valid state purpose. ${ }^{468}$ The plaintiffs, however, introduced evidence of alternative methods of determining assignment to EMR classes used by other school systems, which minimized reliance on IQ tests. ${ }^{469}$ Thus the defendants failed to meet their burden of proof.

Larry $P$. v. Riles, however, was only a nominal victory for the plaintiffs. The

461. See Note, Hobson v. Hansen: Judicial Supervision of the Color-Blind School Board, 81 HARv. L. REv. 1511,1521 (1968).

462. Charters, Social Class and Intelligence Tests, in SChool ChILdREN IN The URbax Slums 75 (J.

Roberts ed. 1967).

463. 269 F. Supp. at 515

464. 269 F. Supp. at $508 \& 515$.

465. See, e.g., Stewart v. Phillips, Civil No. 70-1199-F (D. Mass. Feb. 8, 1971).

466. 343 F. Supp. 1306 (N.D. Cal. 1972).

467. Id at $1314-15$.

468. 343 F. Supp. at 1313 .

469. 343 F. Supp. at 1313-14. 
court refused to order the immediate testing of all black students then in EMR classes; refused to order affirmative action to compensate black students who had been wrongfully placed in EMR classes in the past; and refused to order the hiring of minority group psychologists and consultants for the administration of tests to minority students, and evaluation of the test scores. ${ }^{470}$ The court was also extremely wary of, and refused to grant plaintiffs' request for an EMR class-quota system (whereby the percentage of black students could exceed the percentage of black students in the school district as a whole by no more than fifteen per cent), because ${ }^{471}$

\begin{abstract}
it [would leave] fulfillment of the needs of retarded black students at the mercy of white parents who may decline to consent to placement of their own retarded children in EMR classes and thereby reduce the number of retarded black children who may be placed in them.
\end{abstract}

And the battle continues. The Portsmouth, Virginia School Board is currently under legal attack in the Federal District Court for the Eastern District of Virginia because of its use of $I Q$ tests for placement of children in special classes and in schools for the mentally retarded. The plaintiffs claim that black students have been misclassified and wrongly assigned to such classes. The plaintiffs are not seeking to abolish all IQ testing, but only those tests which do not take into account the socioeconomic background of the students being tested. In addition, plaintiffs are seeking testing which assesses "sensitivity, vocational, technical and mechanical skills, styles of analysis and the ability to express one's self through oral, non-verbal or graphic means." ${ }^{42}$ Testifying for the plaintiffs was Dr. Jonas Chenault, an educational psychologist at the University of Michigan.

Defendants, on the other hand, stressed the importance of the IQ tests in determining which students need special help, and expressed concern that the Supreme Court might abolish the use of IQ tests altogether. The school board also strongly objected to the plaintiffs' allusion to a recent study which allegedly showed that while white students who score below 70 on the IQ tests are generally retarded, blacks who score below 70 are not necessarily retarded. ${ }^{473}$

A number of similar cases which have been brought have been settled. Stipulations in some of these cases acknowledge that large groups of Spanishspeaking children have been inappropriately placed in EMR classes after being tested in English. Perhaps the most significant of these is Diana v. State Board of Education ${ }^{\mathbf{4 7 4}}$ which undoubtedly influenced the California legislature's substantial revision of the testing and classification procedures for EMR classes then in

470. 343 F. Supp. at 1314.

471. 343 F. Supp. at 1315 .

472. Washington Post, April 19, 1974, $§ \mathrm{D}$, at 1, col. 1. The case was filed in the Federal District court for the Eastern District of Virginia.

473. Id.

474. Civil No. C-70-37-RFR (N.D. Cal. Jun. 18, 1973). See Classification Materials 199-207, 224-29, 429 . 
use by the California school system. ${ }^{475}$ The plaintiffs in that case brought a class action challenging the use of $1 Q$ tests to place Mexican-American children in EMR classes, ${ }^{476}$ alleging that the nine named children were not mentally retarded; rather, their low test scores resulted from their unfamiliarity with the English language. Each of the nine named plaintiffs was retested, and the children were allowed to answer either in English or in Spanish. All performed significantly better, averaging, as a group, a fifteen point increase in IQ. Seven scored higher than the maximum score used for assigning children to EMR classes. Less than a month after the suit was filed, a stipulation order was entered requiring that children be tested in their primary language and interpreters be used in the absence of a bilingual examiner; that Mexican-American and other foreign language children then in educable mentally retarded classes in the county be retested and reevaluated; that assistance be provided to misplaced children to enable them to readjust to regular classes; and that the state develop and standardize an $1 Q$ test on a Mexican-American population living in California. ${ }^{47}$

475. C:Al. Educ. Code $\$ 6902.06$ (West Supp. 1972). The Director of the Office of Civil Rights of the Department of Health, Education and Welfare, issued a departmental memorandum noting that schools were not to assign students whose predominant language was other than English to EMR classes on the basis of rests which measured English language skills. 35 Fed. Reg. 11, 595 (1970). Subsequently, OCR cited twenty-eight districts in the Southwest for noncompliance with Title VI; of these, fourteen assigned Mexican-American students to EMR classes on the basis of criteria measuring English language skills. U.S. Commission on Civil Rights. MexiCAN AMEriCAN Education Study, Report VI: Toward Quality Education for Mexican AMericans $58-59$ 1974).

476. The IQ test used by the school system, which was challenged by the plaintiffs was the verbal Stanford-Binet test, which was standardized in 1937 on 3.184 white native-born Americans and has never been restandardized. Plaintiffs asserted that the cultural bias of the test was selfevident when such questions are asked as "Why is it better to pay bills by check than by cash?" (Plaintiffs point out that this is a difficult question for a child whose parents have never had a bank account) and "Who wrote Romeo and Juliet?" The vocabulary section includes the words "umbrella," and not "sombrero," and "chattel," not "slave." The children are also asked to identify such items as "C.O.D." and "hieroglyphic." Id. at 202.

477. The stipulation order also required the California State Department of Education to maintain data on the racial and ethnic composition of all EMR classes in each school district; if there is a higher proportion of racial or ethnic children in the EMR classes than their proportion in the district as a whole, the school district will be required to explain the difference.

One commentator notes that as a result of Diana and the new California law. supra note 475. thousands of children have been returned to regular classes. The commentator notes, however. that the needs of these children are not being adequately provided for:

[A] closer look at the situation presents a dismal picture. Children being returned o the regular classes are provided little of the necessary additional support, enrichment, and remedial services which will redress the effects of their prior educational experiences and permit them to function at the level of other students in the regular classes. Apparently, they are not expected to do well, and many will not. It seems certain that the blame for their failure will be placed on the children, rather than on a sistem that will not modify itself and its resources to meet their particular needs.

Cohen \& DeYoung, The Role of Litigation in the Improvement of Programming for the Handicapped, in The First Review of Special Education 270 (L. Mann \& D. Sabatino eds. 1973).

See also Guadalupe Organization, Inc. v. Tempe Elementary School Dist., Civil No. 7 1-435 (D. Ariz. May 9, 1972). The complaint in that case states that Spanish-surnamed children comprised 67.5 per cent of the enrollment in EMR classes and 46.34 per cent of the enrollment in classes for 
If legal rights in fact do accrue to minority children who have been wrongly assigned to a lower track or an EMR class on the basis of such tests, what remedies are available? Reassignment to a higher track or into "mainstream" classes? Compensatory education? Monetary damages for a diminished future earning capacity? ${ }^{478}$

Assuming, however, that the tests used to identify mentally retarded students are racially neutral, culturally fair, and educationally valid, should the tests or the assignment to special classes on the basis of those tests be open to legal challenge if the result is a disproportionate number of minority children being placed in special classes or schools for the educable mentally retarded? Social science has not yet resolved the question of whether it is educationally wiser to remove educable mentally retarded students from the "mainstream" of education by placement either in special classes or schools or to keep these students in regular classrooms while providing supplemental supportive training both in and out of class. It has been argued that such "mainstreaming" would reduce any stigma attached to placement in special education, as well as prevent the psychological and educational harm arising from misclassification, but there are equally valid educational arguments for separating such children from the others. ${ }^{49}$ In view of the uncertainty as to which educational proce-

trainable mentally handicapped, although they comprised only 17.78 per cent of the total student population. This case was also terminated by a stipulated settlement.

Covarrubius v. San Diego Unified School Dist., Civil No. 70-394-5 (S.D. Cal. Aug. 21, 1972), also resulted in a settement agreement. The plaintiffs in that case not only asked for injunctive relief against the continued use of the tests as devices for student assignment-enjoining defendants from administering tests to students who may do poorly on them because of their cultural background and enjoining defendants from placing any child in a special education class before age 10 -but also for $\$ 400,000$ in punitive damages for the period they had spent in mentally retarded classes because of mislabeling. As a result of the settlement agreement, no punitive damages were awarded.

In Ruiz v. State Bd. of Educ., Civil No. 218294 (Super. Ct. Sacramento County, filed Dec. 16, 1971), plaintiffs sought an injunction to prevent the defendants from administering and recording in the plaintiffs' permanent cumulative school records the results of group intelligence tests, which California law requires be given to all sixth and welfth grade students. The complaint alleges that the tests are designed with reference to middle-class white cultural norms and have no validity in measuring plaintiffs" ability. Despite this, the scores are placed in the permanent records and "are relied upon by teachers, counselors, and school administrators to develop low ability expectations for them and to track, teach. place. evaluate and encourage them accordingly." Cilassification Materials 289.

478. Cf. Peter Doe v. San Francisco Lnified School Dist.. Civil No. 653-312 (Super. Ct., San Francisco County, filed Nov. 20, 1972). Plaintiff, an 18-year old high school graduate, filed an action seeking general and punitive damages of one million dollars from the school authorities on the ground that he could neither read nor write above fifth-grade level despite having received his high school diploma and despite the school system's repeated reassurances to his mother that he was progressing at a normal grade-level rate.

479. Compare Dunn. Special Education for the Mentally Retarded-Is Much of It Justifiable:. 35 Exceptional Childrex 5 (1968) ath MacMillan, Special Education for the Mildy Retarded: Servant or Savant: 2 Foces ox Exceptional. Cintldrex no. 9. at 1 (1971). A summary of some of the arguments for and against special classes for the retarded is provided in Fink \& Glass, Comtemporary Issues in the Eduction of the Behatimally Disordered, in THE. First Review OF Special EnUCaTION 137 (L. Mann \& D. Sabatino eds. 1973). 
dure is more appropriate, should courts intervene? It is at least arguable that once a court has determined that the tests being administered are racially neutral and otherwise valid, and that there are procedural and substantive safeguards to circumscribe the classification process to avoid even unintentional misclassification, there is no basis for a court to intervene further. The difficulty courts face here is in developing remedies that will cure the civil rights violations without interferring with legitimate educational judgments about the need to group children by ability.

\section{Student Discipline}

There is a growing body of evidence indicating that within "integrated" schools and school systems a disproportionate number of black students are suspended, expelled, or otherwise disciplined. ${ }^{480}$ This systematic exclusion is now being attacked in the federal courts. In Hawkins $v$. Coleman,$^{\mathbf{4 8 1}}$ it was found that blacks in the Dallas school system were systematically suspended more frequently, endured longer suspensions, and were also subjected to corporal punishment much more often than whites-particularly in schools where whites were a majority. ${ }^{482}$ The Dallas superintendent testified that this was attributable to "institutional racism." ${ }_{483}$ Testimony from a psychologist indicated that black students would become "more frustrated as the institution continue[d] to refuse to respond to their needs and ambitions" and that "[t]his frustration [would] be reflected either in increased passivity or increased hostility," the latter, of course, resulting in increased "suspendable behavior." 484

As with ability grouping practices, it is not clear in this area when actions are taken for valid educational reasons and when a court should intervene to protect the rights of minority students. If the actions are taken without intent to discriminate and with adequate procedural safeguards, but the result is a disproportionate number of minority children being disciplined, the same question must be asked: is it appropriate for courts to intervene? ${ }^{45}$ And if it is appropriate, what remedies can the courts fashion which will safeguard the rights of minority students, yet leave school officials unfettered to pursue legitimate disciplinary goals? The case law on these points at present is, at best, rudimentary. In the coming years, these "second generation" problems will undoubtedly be a principal focus of attention.

480. See generally Children's Defense Fund, Children Out of School in America (1974); Hearings on Equal Educational Opportunity Before the Select Senate Comm. on Equal Educational Opportunity, 91 st Cong., 2d Sess., pt. 3-B, at 1311 (1970).

481. 376 F. Supp. 1330 (N.D. Tex. 1974).

482. Id. at 1333-35. See generally Yudof, Suspension and Expulsion of Black Students From the Public Schools: Academic Capital Punishment and the Constitution, 39 LAw \& Contemp. Prob. no. 2, at 374 (1975).

483. 376 F. Supp. at 1336.

484. Id.

485. See Yudof, supra note 482, for an excellent discussion of the complexity of the problem of black exclusion from public schools. 


\section{Summary and Conclusion}

A summary of the development of school desegregation law-spanning the nineteen year period from Brown to Keyes-reveals the following principles for court-ordered school desegregation:

1) Immediate desegregation is required; delays will no longer be tolerated. ${ }^{486}$

2) All-out desegregation must be accomplished and segregation eliminated "root and branch." 487

3) In designing a desegregation plan for a formerly dual school system, federal district courts have broad equitable remedial powers-whatever tools are necessary; "[o]nce a right and a violation have been shown, the scope of a distric court's equitable powers to remedy past wrongs is broad, for breadth and flexibility are inherent in equitable remedies." 488

4) Remedies "may be administratively awkward, inconvenient, and even bizarre in some situations . . ."; ${ }^{499}$ thus noncontiguous and noncompact attendance zones-even zones which "may be on opposite ends of the city"-Can be drawn by the district court. ${ }^{490}$

5) There are limits on the extent to which some remedial measures can be used:

a) Racial balance-there is no substantive constitutional right to racial balance in and of itself, ${ }^{491}$ but as a remedy for an already determined constitutional violation, mathematical ratios may be used as a "starting point." 492

b) Busing-may be used where feasible, limited only "when the time or distance of travel is so great as to either risk the health of the children or significantly impinge on the educational process." 493

6) In an area where no prior statutory or constitutional provision has compelled segregation, de jure actions of school officials (e.g., manipulating attendance zones or selection of sites for new school construction) in one part of the district (albeit a "meaningful" part) leads to the presumption that the "infection" has pervaded the entire district or that de jure actions must have occurred throughout the district. ${ }^{494}$ The de facto/de jure distinction is still alive. ${ }^{495}$ However, it is probable that plaintiffs can with relative ease prove intentional segregative acts on the

486. Alexander v. Holmes County Bd. of Educ., 396 U.S. 19, 20 (1969). See also Carter v. West Feliciana Parish School Bd., 396 L.S. 290 (1970).

487. Green v. County School Bd., 391 U.S. 430, 437-38 (1968).

488. Swann v. Charlotte-Mecklenburg Bd. of Educ., 402 U.S. 1, 15 (1971).

489. 402 U.S. at 28.

490. 402 U.S. at 27

491. 402 U.S. at 24

492. 402 L.S. at 25.

493. 402 U.S. at 30-31.

494. Keyes v. School Dist. No. 1. 413 L.S. 189, 208-09 (1973).

495. 413 U.S. at 208. 
part of school officials or actions "which have the natural and foreseeable consequences of causing educational segregation," 496 of a school district. This coupled with the presumptions that are triggered by such a finding, ${ }^{497}$ suggest that Justice Powell's demand-that there be a "uniform national rule"498 for school segregation-would very likely be met.

Thus in the nineteenth year after the Brown decision, it seemed clear that de jure segregation could be found in school districts outside of the South; that the burden of proof, once a prima facie case was made by plaintiffs, would be on the defendant school system to prove either that the pattern of segregated schools was not a "vestige" of a formerly dual state-imposed system ${ }^{499}$ or was not the result of racially motivated actions of school officials ${ }^{500}$ and that there were no limits on the equitable remedial powers of federal district courts in providing for all-out desegregation other than those noted above with regard to busing and racial imbalance. There was little indication that the remedial measures which a court could impose could run only to the school district line.

But some cracks had begun to appear in the unanimous front heretofore presented by the Court, as indicated in various concurring and dissenting opinions:

1) "Local control," it was suggested, was desirable and of "overriding importance from an educational standpoint" and weighed heavily against any remedial measure which would interfere with the independence of already defined separate school districts. ${ }^{501}$

2) Deviations in racial balance percentages should not prevent a school system from withdrawing from a larger unit and setting itself up as a separate district to provide "quality education." ${ }_{502}$

3) "In the balancing of interests," busing should be curtailed when it is at the expense of a neighborhood schools policy. ${ }^{503}$

4) Racial gerrymandering of attendance zones or other deliberate segregative actions in a part of the school district is a constitutional violation only as to the minorities within that zone; unless factual inquiry reveals that invidious discrimination has taken place in every zone, the district as a whole can not be treated as a "dual" school system requiring a districtwide remedy. ${ }^{504}$

Twenty years after Brown, Milliken v. Bradley-the Detroit case-was

\footnotetext{
496. Hart v. Community School Bd. of Educ., 512 F.2d 37.50 (2d Cir. 1975 ).

497. See notes 74-80 accompanying text at pp. 63-64 supra.

498. 413 U.S. at 232.

499. Swann v. Charlotte-Mecklenburg Bd. of Educ., 402 U.S. at 15.

500. Keyes v. School Dist. No. 1, 413 U.S. at 208.

501. Wright v. City of Emporia, 407 U.S. 451 (1972) (Burger, C.J., dissenting).

502. See 407 U.S. at $478-82$ (Burger. C.J.. dissenting).

503. Keyes v. School Dist. No. 1, 413 U.S. at 189. $251-52$ (1973) (Powell, J., concurring in part and dissenting in part).

504. 413 U.S. at 256-58 (Rehnquist. J.. dissenting).
} 
decided..$^{305}$ The immediate reaction among many was that this was the end of the line. The burden of proof was shifted from the defendants to the plaintiffs to prove the actions of suburban school officials or of state education officials were racially motivated and had a segregative effect on the central city district. But the decision need not necessarily be seen-as Justice Marshall suggests-as "a giant step backwards." ${ }^{506}$ The door was left slightly ajar to permit proof of intentional actions of state or suburban non-school governmental agencies to establish or maintain residential segregation. ${ }^{507}$ Moreover, the admission by the majority that the segregation in Detroit was clearly de jure indicates that school desegregation litigation can continue unabated in the North and West as long as relief is sought on an intra-district basis. There seems to be no withdrawal from Swann and Keyes.

What function has social science research served in the foregoing legal development and of what relevance will it be in future litigation? First, social science research since Brown has not generally been used by the courts to ascertain some degree of "harm" as a predicate to a constitutional violation, although to some extent demographic and other studies have been used to determine whether segregation is attributable to actions of school officials, other officials, or is fortuitous.

There are at least three significant areas in which social science research has been and can be useful to courts. The first area is that left open by the Detroit decision-proof of racial containment in the central city schools by actions of suburban or state agencies. Clearly demographers, sociologists, political scientists and others can aid in determining the factors leading to the "growing core of Negro schools" in the central city, surrounded by nearly all white suburban school districts.

The second area is that of the desegregation plan itself-social scientists and social science data can be and are used to help the court translate from desegregation as simply a "body count" to effective integration. The development of a separate remedial plan for Hispano-Americans in Keyes to reflect the unique bilingual-bicultural needs is such an example. ${ }^{518}$ Thus, educators, psychologists, sociologists and others are useful in tailoring remedies to the particular needs of litigants.

The third area concerns the problem of resegregation within the school or classroom even though the school system is unitary. Social science data have frequently been drawn upon to show the misclassification, as mentally retarded, of a disproportionate number of minority children and the inappropriateness of the tests used in the classification process. Social science also

505. 418 L.S. $717(1974)$.

506. 418 L.S. at 782 (Marshall. J., dissenting).

507. Clearly Justice Stewarts concurring opinion secks this kind of cridence, se 418 C.S. at 790-808. but the majority may also be recoptive wo such evidence. See 418 L.S. at 48-52.

508. See 413 L.S. al 145-98. 
suggests, however, that in the absence of clear racial motive, it may not be appropriate for courts to intervene in various educational policy questions such as ability grouping and tracking, the "mainstreaming" or separation of children who are mentally retarded, and the use of disciplinary measures. The courts more appropriately should intervene only to determine whether otherwise valid educational policies actually are used to resegregate and to ensure that minimal due process requirements are met.

To conclude, the legal issues in the field of public school desegregation have become considerably more complex since the focus shifted away from the southern states to the rest of the country. The question of whether the constitution has been violated now involves a search for unobtrusive and racially benign actions which might have contributed-directly and indirectly-to the perpetuation of a dual school system. Once a violation has been established, an even more perplexing question becomes how can segregation effectively and fairly be remedied. This increasing complexity requires and will continue to require that courts work from a more solid foundation of fact than ever before in deciding questions of law. Judges will find it increasingly necessary to consider and rely on the testimony of demographers, educators, psychologists, sociologists, and political scientists simply in order to fully understand the nature of the legal issues that are being presented and the likely impact various remedies will have. It is this legal development which places increasing importance on the research of social scientists.

As was stated in the introduction, this article has not attempted to outline the agenda for cooperation between the law and the social sciences. But in delineating the complex unresolved issues in the law of public school desegregation, we recognize the vast potential of social science research as a valuable evidentiary means to realize the promise of Brown. The quality of constitutional justice will be enhanced as social scientists and jurists strive to discover and understand the "unknown and perhaps unknowable." 